UNIVERSIDADE DE BRASÍLIA

INSTITUTO DE ARTES

DEPARTAMENTO DE MÚSICA

\title{
PULSANDO JUNTO: CAIXEIRAS DO DIVINO E SUA MÚSICA DIASPÓRICA
}

MARISE GLÓRIA BARBOSA

BRASÍLIA

01/2015 


\section{MARISE GLÓRIA BARBOSA}

\section{PULSANDO JUNTO: CAIXEIRAS DO DIVINO E SUA MÚSICA DIASPÓRICA}

Dissertação apresentada ao Programa de Pós-graduação em Música do Departamento de Música da Universidade de Brasília, como requisito parcial para obtenção do grau de Mestre em Música.

Área de concentração: Processos e produtos na criação e interpretação musical.

Orientador: Prof. Dr. Antenor Ferreira Correa

\section{BRASÍLIA}

$01 / 2015$ 
Ficha catalográfica elaborada automaticamente, com os dados fornecidos pelo(a) autor(a)

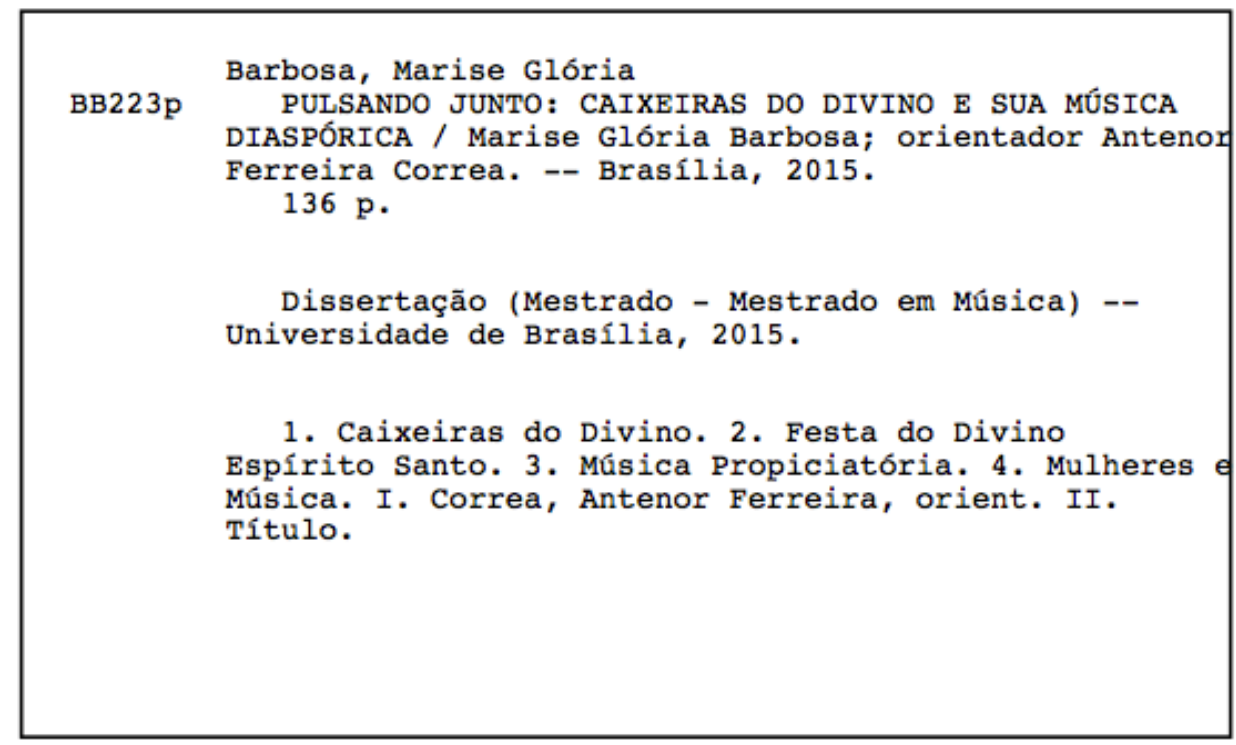




\section{MARISE GLÓRIA BARBOSA}

\section{PULSANDO JUNTO: CAIXEIRAS DO DIVINO E SUA MÚSICA DIASPÓRICA}

Dissertação apresentada ao Programa de Pós-graduação em Música do Departamento de Música da Universidade de Brasília, como requisito parcial para obtenção do grau de Mestre em Música.

Área de concentração: Processos e produtos na criação e interpretação musical.

Orientador: Prof. Dr. Antenor Ferreira Corrêa

Banca Examinadora

Antenor Ferreira Corrêa (orientador)

Universidade de Brasília - UnB

Hugo Leonardo Ribeiro (Membro Interno)

Universidade de Brasília - UnB

Letícia Costa R. Vianna (Membro Externo)

INCTi - UnB

Aprovado em 21 de maio de 2015 


\section{AGRADECIMENTOS}

Agradeço profundamente às Caixeiras do Maranhão, inspiradoras em sua fascinante trajetória, em particular as da Casa Fanti Ashanti, minhas mestras!

Agradeço a cada pessoa que pude encontrar em cafés, cervejas, visitas, incontáveis situações de acolhimento e diálogos com infinitas importâncias.

Sou grata ao meu orientador, Prof. Antenor Correa Ferreira, por suas valorosas leituras e sugestões, aos(às) professores(as), em particular Hugo Leonardo Ribeiro pelos apoios, discussões e sugestões. A Maria Cecília Jorquera, pelas partituras, observações e sugestões valorosas. Sou grata a meus colegas e suas questões, e aos apoios que não pude perceber.

Sou grata a Carol Barbosa Soares e Jaqueline Fontenelle pelos suportes, Carmem Fontenelle pelos abrigos em sua casa e Vanessa Fontenelle pela moradia na Chácara. Fundamentais!

Sou grata à vida, suas sutilezas, seus perigos.

Agradeço a você que se dispõe a ler. Agradeço ainda mais a quem se dispuser a comentar e, para isso, disponibilizo meu e-mail: marisegloria.barbosa@gmail.com 


\section{RESUMO}

Nesta pesquisa tive como objetivo conhecer a música das Caixeiras do Divino em suas formas contemporâneas, em construções musicais desenvolvidas em zonas de contato (Hall 2003) construídas no processo de colonização e sua continuidade para além dele. Estas formas foram aqui compreendidas como construções, e não redescobertas e aportam relevantes informações sobre a nossa formação intercultural, transnacional. Este trabalho inclui dados sobre o amplo contexto histórico do povoamento do Maranhão como apoio para uma aproximação do universo no qual se construiu a música e os cultos festivos ao Divino. A pesquisa, sobre esta construção musical, seus processos de livre apropriação e recombinação de elementos, foi apoiada também por análises estruturais em estreito diálogo com o contexto no qual ela é produzida. Estas análises são um suporte para o diálogo com os significados atribuídos pelas Caixeiras a seu repertório musical, os quais oferecem outras possibilidades de leitura para os dados objetivos construídos pela pesquisa.

Palavras chaves: Caixeiras do Divino; Festa do Divino Espírito Santo; Música Propiciatória, Mulheres e Música. 


\begin{abstract}
The goal of this research was to get knowledge about the music of Caixeiras do Divino in its contemporary forms, within musical constructions developed in contact zones (Hall, 2003), during diasporic process in the colonization time. Those forms were comprehended as constructions, instead rediscoveries, and holds relevant information about our intercultural and cross-national formation. It were included data about the historic context belonging to the population of Maranhão (Brazil) with the intention to provide a support to claim a relationship between Holy Spirit festive worships and the music of Caixeiras do Divino. To that, It was studied geographic aspects related to different regions of Maranhão. The research about the musical construction of Caixeiras do Divino involved musical analysis. These analysis also intended shedding light on the process of free apropriation e recomposition of elements intrinsec to this repertoire. These analysis were accomplished within a contextual thinking, that means, always having in mind the social context where this music is created. Thus, these analysis offer a support for the dialog between the music and the meanings atributed to it by the Caixeiras do Divino, showing other possibilities for reading the data produced in this research.
\end{abstract}

Key words: Caixeiras do Divino, Holy Spirit Festivity, Propitiatory Music, Women and Music. 


\section{LISTA DE FIGURAS}

Figura 01 - Caixeiras do quilombo Santa Rosa dos Pretos em festejo na 50 comunidade

Figura 02 - Mapa das Microrregiões do Estado do Maranhão 54

Figura 03 - Mapa: Estados do Brasil e do Maranhão e Grão-Pará 56

Figura 04 - Partitura do Espirito Santo Dobrado $\quad 80$

Figura 05 - Pancada $\quad 81$

Figura 06 - Tripla repetição de Pancada $\quad 81$

Figura 07 - Espirito Santo Sobrado ou Três Pancadas $\quad 81$

Figura 08 - Partitura de Nossa Senhora da Guia 89

$\begin{array}{lll}\text { Figura } 09 \text { - } \quad \text { Partitura de Alvorada } & 94\end{array}$

Figura 10 - Toque Alvorada 95

Figura 11 - Ciclo completo do Toque Alvorada 96

Figura 12 - Partitura de Alvoradinha 101

Figura 13 - Hemíola no Toque Alvoradinha 102

Figura 14 - Partitura de Senhora Santana 106 


\section{SUMÁRIO}

INTRODUÇÃO: SEGUNDO MOVIMENTO, MESMA DIREÇÃO .......................... 11

(Perfil Profissional), Métodos, Conceitos e Abordagens em Etnomusicologia......... 14

Mulheres e música: experiências, conceitos, abordagens...................................... 19

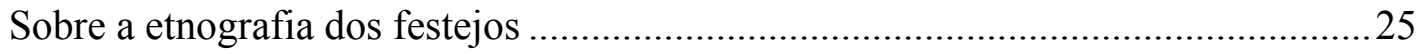

Objetivos e métodos neste segundo movimento: Os caminhos se fazem ao caminhar.

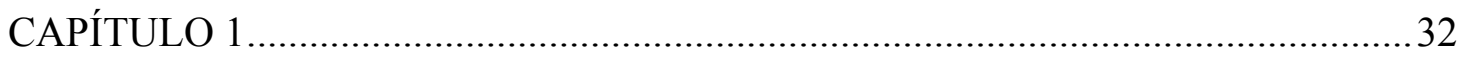

1.1 - Alguns dados contemporâneos sobre a popularidade das Festas do Divino ....32

1.2 - Um pouco da história da festa e conexões entre universos simbólicos.............33

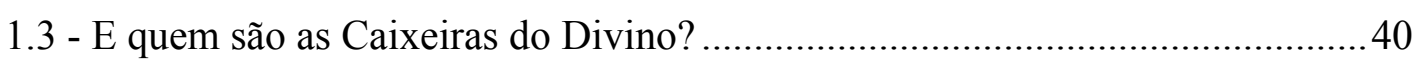

1.4 - Paralelos históricos: mulheres tocando nos Festejos dos Açores e do Maranhão .48

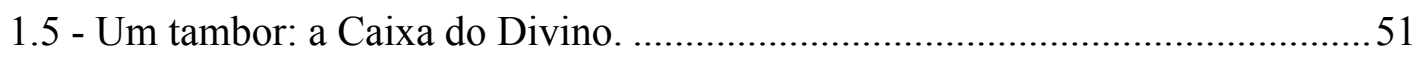

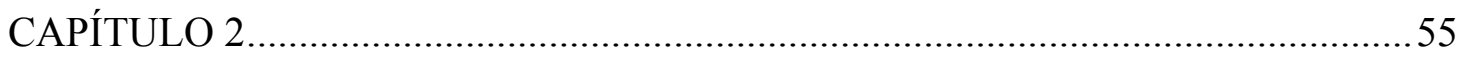

2.1 - Os movimentos de população aos olhos desta Festa .......................................55

2.2 - Diálogos entre o repertório musical e os roteiros rituais dos Festejos .............67

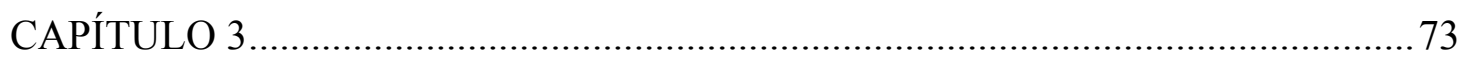

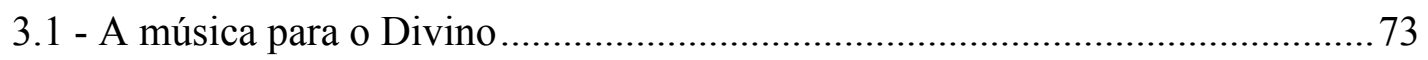

3.1.1 - Estruturas sonoras e performáticas da música afro-brasileira tocada nos Terreiros, de acordo com critérios definidos por Gerhard Kubik ................................. 75

3.1.2 - Estruturas sonoras e performáticas da música tocada pelas Caixeiras nos

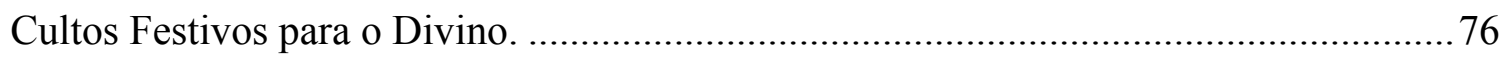

3.2 - O cenário onde quase tudo acontece: A Tribuna........................................... 77

3.3 - Parêntesis para apresentar as partituras ..................................................... 80

3.4 - Abertura da Tribuna: Espírito Santo Dobrado, ou Três Pancada..................... 81

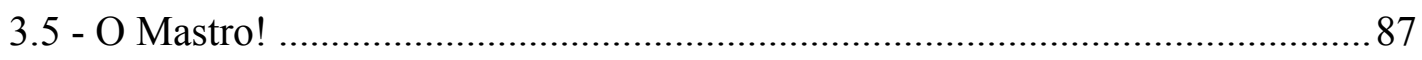

3.5 - Levantamento do Mastro - O Toque? Nossa Senhora da Guia....................... 91 
3.6 - Alvorada

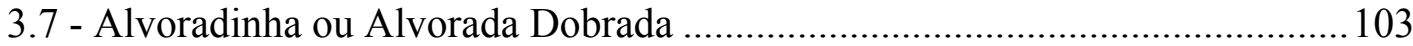

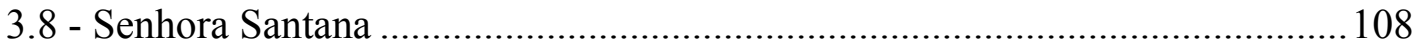

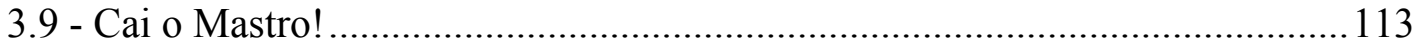

3.10 - Fechamento da Tribuna, final do festejo ................................................... 120

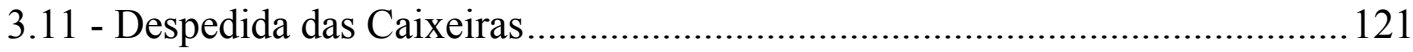

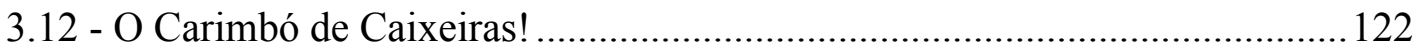

AQUILO É DAQUELAS PRETADAS VELHAS, ANTIGAS, ESCRAVAS! AS

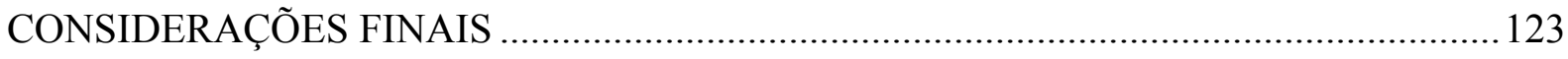

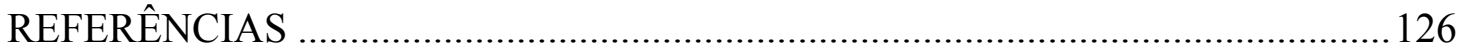

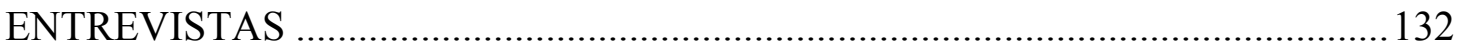

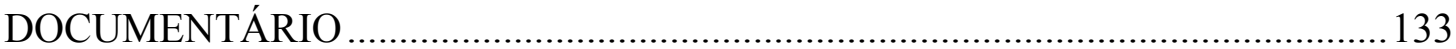

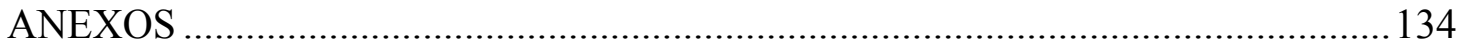

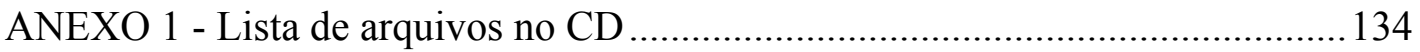

ANEXO 2: Alvorada na Casa Fanti Ashanti ......................................................... 135

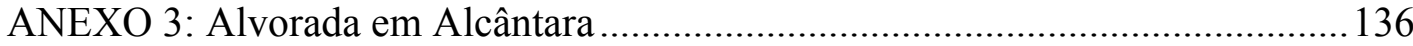




\section{INTRODUÇÃO: SEGUNDO MOVIMENTO, MESMA DIREÇÃO}

Paisagens sonoras e visuais que incluem a passagem de Ternos de Congo e Moçambique pelas ruas, com tambores, corpos suados cantando e dançando sob o sol quente, estão presentes nas dobras da sociedade contemporânea. São conhecidas nas zonas rurais, mas também em áreas urbanas, em morros, periferias e mesmo em grandes centros, inclusive em áreas onde predominam as classes médias ${ }^{1}$. Folias de Reis cantando e visitando casas durante a noite, Folias do Divino durante o dia. Cultos festivos que rompem com a dinâmica e pragmática capitalista, incluindo refeições coletivas, abertas a quem chegar.

Esses cortejos devocionais têm também a função de marcar o tempo durante o ano, dividindo-o em tempo dos Congos, Reis, Divino. A complexidade presente nesse universo se expressa na música plena de significados coletivamente construídos e estruturada por cantos e percussão em diálogo estreito com a dança. São epistemologias manifestas em textos de cantiga, de evocação, de história contada e cantada, em performances pelas ruas e lugares, sacralizados pelas cosmogonias afro católicas.

Os conhecimentos assim produzidos, são indivisos entre arte e vida. Desenvolvem-se em "modos de viver onde artistas são intelectuais, desencadeando sensibilidades e percepções em comunidades onde imbricações de letra e corpo marcam presença" ensina a historiadora Maria Antonieta Antonacci (ANTONACCI, 2013, p. 257) em consistente defesa de gêneros não verbais de narratividade, inerentes a culturas às margens da civilização ocidental cristã.

Porém, destaque-se que tocar os tambores e cantar para conduzir a música propiciatória em rituais são funções e espaços simbólicos comumente interditados às mulheres. Essa realidade dialoga com outra; desde o século XIX na Europa, há um grande movimento de feminização da religiosidade, inclusive com o investimento de mulheres na construção de confrarias, tema ao qual se dedica o trabalho de Maria Marta Lobo de Araújo, $A$ Ajuda aos Pobres na Confraria de Nossa Senhora da Guia e do Espirito Santo de Ponte de Lima. Sec. XVII a XIX, publicado em 2001 como separata do Vol. I da Revista Cultural Bracara Augusta, em Braga, Portugal.

\footnotetext{
${ }^{1}$ Podemos citar a presença da Associação Cultural Cachuêra!, em São Paulo, que tem como um dos focos de seu trabalho as culturas tradicionais no Brasil, e que para aquele espaço e pelas ruas ao redor, levam festejos, cortejos, oficinas, performances, além de manter um importante acervo com seu repertorio musical. A Cachuêra!, está no bairro das Perdizes em São Paulo, um bairro de classes médias altas.
} 
Mulheres musicistas, antropólogas, arqueólogas, têm pesquisado e ampliado o conhecimento e a compreensão das interdições sociais, rituais, culturais ou históricas ao fazer musical das mulheres. Felizmente essas, pensadoras são incontáveis, mas destaco algumas que pude ler em momentos decisivos. Entre elas a musicista Sophie Drinker em Music and Woman: The history of woman in their relation with music, um trabalho de 1943; a percussionista e pesquisadora Layne Redmond, When the drummers were women, publicado em 1997; etnomusicóloga e performer Judith Cohen, CanoSoe joglaresa: Women and music in Medieval Spain's: Three Cultures, presente em Medieval Woman's Song Cross Cultural Aproaches de 1997; e a musicóloga Susan McClary; Conventional Wisdom: The Content of Musical Form, de 2000 e Of patriarchs and matriarchs too, de 1994.

O caminho iluminado por faróis potentes como esses, torna evidente que a cultura das mulheres Caixeiras do Divino é indicativa de uma antiga, longa e importante realidade na história das mulheres em sua relação com a música.

Venho trabalhando na compreensão desse universo onde estão as Caixeiras desde meu primeiro encontro com elas em São Luís, no Maranhão, em 1993. Até então minha atenção se concentrava em perguntar: "Por que não há mulheres tocando em rituais cuja música propiciatória envolve o canto e a percussão de tambores?” Eu não percebia, até então, que questões como essa comumente se localizam no terreno das múltiplas representações simbólicas de difícil compreensão. O encontro com elas em 1993 foi paradigmático e a pesquisa se reorientou. A partir de então, a pergunta "por que não tocam?" se reorientou para conhecer as condições socialmente dadas nas quais mulheres conduzem rituais com o canto e o toque de tambores, um empenho dirigido aos cultos festivos ao Divino Espírito Santo e à presença das Caixeiras do Divino no Maranhão.

Com o objetivo de conhecê-lo, fui para o Programa de Pós-Graduação em História Social na Pontifícia Universidade Católica de São Paulo e finalizei um primeiro momento nesse caminho de pesquisa com a dissertação: Umas mulheres que dão no couro: As Caixeiras do Divino no Maranhão. Título que, por seus sentidos abertos a interpretações, foi escolhido por dialogar com o fato de que elas tocam tambores, instrumentos de percussão com superfícies de couro. Refere-se também à assertividade revelada em sua performance ao tocar e cantar em uníssono, mantendo firmemente ritmos/toques complexos e estreitamente relacionados aos diferentes tempos do roteiro ritual da Festa do Divino, em um sofisticado conhecimento desenvolvido no universo da oralidade que guarda as memórias do corpo. 
A pesquisa foi realizada pelo método clássico em etnografia com a imersão no universo dos festejos. E o suporte teórico para reflexão incluiu os Estudos Culturais, a História, a Semiótica, as Religiões, os estudos históricos e antropológicos sobre o Divino Espírito Santo, Oralidade e suas abordagens. Nessa trajetória, o trabalho com depoimentos orais dialogou com uma escolha política e metodológica para a construção das informações. A palavra das mulheres Caixeiras, sua interpretação do universo no qual são protagonistas, apresentariam os contornos da sua própria experiência. A essa escolha se aliou um dado de realidade: no ano 2000 eram poucos os trabalhos sobre o tema, o que resultou em pequeno suporte bibliográfico.

Como é previsto em pesquisas que envolvem estudos em campo, pesquisadores(as) estabelecem relações pessoais e assumem responsabilidades com as pessoas daquele universo foco de sua pesquisa. Algumas Caixeiras em Alcântara tinham objetivos claros para a continuidade de sua existência e planejavam uma Casa de Cultura das Caixeiras. Minha pesquisa poderia apoiar a visibilidade que elas buscavam junto às políticas culturais do Governo do Maranhão. Aliada a esse objetivo que elas manifestavam, seguiram-se desdobramentos daquele trabalho inicial, descritos a seguir.

O primeiro desses desdobramentos foi uma conquista; a aprovação de um projeto pelo Programa Petrobras Cultural, que resultou em um livro e um documentário lançados em 2006, e que recebeu o mesmo nome da dissertação: Umas mulheres que dão no couro: As Caixeiras do Divino no Maranhão. A este trabalho, se seguiu a coordenação de uma ação de Salvaguarda do Patrimônio Imaterial das Caixeiras da cidade de Alcântara para a Superintendência Regional do Instituto do Patrimônio Histórico e Artístico Nacional (Iphan), no Maranhão, que resultou em um CD duplo e um folheto, lançados em 2009, com o título: No Bater da Minha Caixa, Estou Convidando as Foliôa.

Atualmente, o material audiovisual gerado por estas ações, encontra-se totalmente digitalizado, o que foi possível pelo apoio da UnB - TV. Uma vez digitalizado, o próximo passo é a constituição de um acervo que disponibilizará os dados e informações daí provenientes. Esse acervo será o início de um Centro de Memória das Caixeiras do Divino. Com este foco, tenho inscrito esse projeto em editais de fomento.

Morando na Chapada dos Veadeiros em Goiás desde 2009, me aproximei do Programa de Pós-graduação Música em Contexto da Universidade de Brasília e em 2012 retomei essa 
pesquisa, estimulada também por reflexões como a de Mia Couto sobre as ancestralidades (COUTO, 2003, p.123):

“...o bom do caminho é fazer a volta, porque de caminhos sem volta, basta o tempo".

Neste caminho de volta, novas perguntas se aliam àquelas que, naquele primeiro momento da pesquisa, não foram possíveis investigar e que seguem se ampliando a cada momento. As muitas formas sociais e históricas pelas quais o passado dialoga com o presente, a busca de compreensão do desenvolvimento do estilo musical das Caixeiras. Tudo isso segue como pergunta.

Este segundo movimento, integra análises estruturais de sua música em estreita relação com o contexto, a presença das discussões de gênero, classes, racialidades, a História, os movimentos de população, a Etnomusicologia e os estudos sobre as diásporas em transversalidade metodológica. Este caminho será detalhado em subitens ainda nesta introdução ao trabalho.

\section{Métodos, Conceitos e Abordagens em Etnomusicologia}

Vinda de áreas do conhecimento externas à Música, deparei-me com as discussões presentes nas disciplinas que constroem a produção intelectual no Programa de PósGraduação Música em Contexto, e busquei compreendê-las no diálogo com meus objetivos. Uma delas, inclinou-se sobre o território da Etnomusicologia, buscando definir quem é o sujeito do qual aquela ciência se ocupa, o universo musical foco de seus esforços: Música não ocidental, não europeia, não canônica? Um dos caminhos propostos para compreensão desse território de ação, passa pela definição do perfil do profissional que pode ser incluído no grupo de pessoas habilitadas para atuar nesse universo: antropólogos, musicólogos, historiadores, feministas?

Apresento a seguir um mosaico orgânico, experiências de alguns musicólogos e etnomusicólogos discutindo a sua compreensão das competências, os métodos, as técnicas e as abordagens normalmente adotadas para os trabalhos na diversidade que caracteriza esse campo. 
O etnomusicólogo francês Vincent Dehoux ${ }^{2}$, em entrevista no I Simpósio de Música em Salvador afirmou que todos os etnólogos podem fazer a etnologia da música - um antropólogo, por exemplo. Mas, no que concerne à Etnomusicologia, para se fazer pesquisa musical é necessário conhecer música, ser especialista, ter ouvido. O código musical é desvendado pelo músico. O dever do etnomusicólogo é fazer o que os outros não podem fazer e, necessariamente, passa pela música.

Em diálogo com essa posição, Tiago de Oliveira Pinto na ocasião professor de Etnomusicologia da Universidade de S. Paulo, propõe a seguinte reflexão sobre o tema:

... pesquisadores encaram a música na sua acepção mais estreita: quando não sabem ler partitura, deixam a manifestação musical de lado por completo, como se ler partitura fosse sinônimo de entender e pré-condição para falar sobre música. Neste contexto, é importante lembrar que em muitas outras culturas se desconhece um termo, cujo signo seja idêntico ao de "música", "music", "zene", "musique", "Musik" etc. Na realidade, música raras vezes apenas é uma organização sonora no decorrer de limitado espaço de tempo. É som e movimento num sentido lato (seja este ligado à produção musical ou então à dança) e está quase sempre em estreita conexão com outras formas de cultura expressiva. (OLIVEIRA PINTO, 2001, p. 222)

Ele acrescenta que a meta definida da Etnomusicologia, desde sua reformulação nos anos 60, é descrever os diferentes agentes e agrupamentos etnomusicais pelas abordagens descritas a seguir:

- Pesquisando suas ações (criação, recepção, transmissão);

- Interpretando as manifestações musicais (através de instrumentos, cantigas, textos, performances, reações);

- Verificando seus conceitos (teorias, valores e normas);

- Analisando os comportamentos psíquicos, verbais, simbólicos e sociais ligados à música. (OLIVEIRA PINTO, 2001, p 226)

Refletindo sobre o perfil do profissional da área e as qualificações exigidas nos Estados Unidos, Bruno Nettl observa variações no tempo e no espaço. Alguns programas de formação profissional em Etnomusicologia são autônomos, outros estão em departamentos de música como uma das especializações em programas de musicologia ou antropologia. Em nível de pós--graduação, “espera-se uma pesquisa de campo em uma sociedade, cultura, ou talvez um gênero musical ou repertório, em que, mais tarde, se torne conhecido como um especialista". (NETTL, 2005, p.6).

\footnotetext{
${ }^{2}$ Pesquisador do CNRS desde 1983, na equipe do Laboratoire de Civilisations à Tradicion Orale (LACITO), o Departamento de Etnomusicologia dirigido por Simha Arom, diretor de Pesquisa.
} 
$\mathrm{O}$ autor elege um conjunto de quatro crenças que considera um credo a partir dos quais ele organiza seus textos, e define Etnomusicologia como:

- Estudo da música na cultura;

- Estudo do universo da música de uma perspectiva comparativa e relativista;

- Estudo que utiliza trabalhos de campo;

- Estudo de todas as manifestações musicais na sociedade.

Bruno Nettl observa, também, que é costumeiro o estreitamento de relações pessoais entre etnomusicólogos em campo e seus sujeitos de pesquisa. Em decorrência disso, o estabelecimento de compromissos e apoios para a mudança de situações de dificuldades em comunidades às quais pertencem.

A Etnografia da música como instrumento para o trabalho de campo, buscando o conhecimento do contexto da música que se quer pesquisar, está na reflexão de Anthony Seeger que apoia a compreensão dos caminhos e metodologias:

A etnografia da música não deve corresponder a uma antropologia da música, já que a etnografia não é definida por linhas disciplinares ou perspectivas teóricas, mas por meio de uma abordagem descritiva à música que vai além do registro escrito de sons, apontando para o registro escrito de como os sons são concebidos, criados, apreciados e como influenciam outros processos musicais e sociais, indivíduos e grupos. A etnografia da música é a descrição das maneiras que as pessoas fazem música. (SEEGER, 2008, p.239)

Quanto à definição de Etnomusicologia, Seeger identifica discordâncias entre seus pares:

Para qualquer um alheio ao campo, os argumentos sobre o que realmente é a Etnomusicologia devem parecer obscuros e pouco sugestivos. Os protagonistas às vezes parecem reivindicar e defender um território conceitual mais que avançar na sua compreensão. (Ibid., p. 240).

Incluídos na reflexão sobre as habilidades requeridas para um trabalho em Etnomusicologia, estão os métodos e técnicas validados pelos profissionais que atuam nessa área e, entre elas, o lugar ocupado pelas análises. Catalisadoras de importantes e extensas discussões, análises costumam ser identificadas como marca da excelência dos estudos nessa área. Porém, seu uso tem sido questionado pela democratização das possibilidades de fazer gravações em campo, em equipamentos com preços cada vez mais acessíveis e qualidades cada vez melhores.

Argumentações sobre os métodos de trabalho e abordagens estão presentes nas 
grandes linhas dos estudos em música: Musicologia Histórica, Nova Musicologia e Etnomusicologia.

O Musicólogo Kofi Agawu ao refletir sobre as análises em diálogo com pesquisadores identificados com o estruturalismo, que utilizam análises das estruturas musicais como método, diz que "o papel da análise é duplo: identificar os diversos materiais de uma composição e definir as formas pelas quais eles funcionam". (AGAWU, 1997, p. 297)

Agawu acrescenta que a análise permite aos praticantes enfrentar "o detalhe de um todo musical" e destaca criticamente que, embora todas as áreas da teoria precisem de análise, os "teóricos", "analistas" ou "praticantes de análise", envolvem-se em sistematizações da música em si, em uma abordagem que considera a música como criação autônoma e independente do contexto e das forças sociais, culturais e históricas nas quais essa criação foi realizada.

Todos os universos musicais exigem análises para sua compreensão? Hugo Ribeiro refletindo sobre o tema em trabalho de 2006, entende que essa discussão pressupõe diferentes abordagens do objeto de interesse da pesquisa. Observa que a exclusão de fatores externos ao som, gera limitações que não condizem com a própria natureza de um estudo musical numa perspectiva pós-modernista. (RIBEIRO, 2006, p. 1)

Antenor Ferreira Correa historiciza e sistematiza informações da trajetória percorrida pelo conceito de análise musical, destacando a expansão dessa prática a partir de comentários analíticos sobre as obras, em programas de concertos e em jornais e periódicos no século XVIII e início do XIX. Correa cita a concepção analítica de Schumann, que escrevia para um desses jornais ${ }^{3}$. Elege quatro pontos sob os quais uma obra deveria ser considerada (CORREA, 2006, p. 35):

- Forma: conjunto, partes separadas, período, frase;

- Composição musical: harmonia, melodia, escritura, estilo;

- De acordo com a ideia particular que o artista desejou representar;

- De acordo com o espírito que subjaz à forma, ao material e à ideia.

Sob a luz desses critérios analíticos, o analista se debruçaria sobre uma obra específica, estudando seus componentes em separado, buscando a melhor compreensão de seus aspectos intelectuais e estéticos. Correa observa que não se inclui, entre os critérios selecionados, referências ao contexto que cria esta música.

\footnotetext{
${ }^{3}$ Allgemeine musikalische Zeitung (AmZ) fundado em 1798 em Leipzig.
} 
Considero pertinentes as argumentações críticas à exclusão do contexto por seu impacto no empobrecimento dos resultados das análises. O sujeito da pesquisa, a música das Caixeiras do Divino, exige a inclusão do contexto como elemento gerador de conhecimento nos procedimentos analíticos incluídos nesta pesquisa.

Hugo Ribeiro destaca que analisar é parte essencial dos processos de transmissão e assimilação do conhecimento musical, mas que a escolha de uma corrente analítica se vincula à função social e contemporânea de uma pesquisa e que toda escolha analítica é uma escolha política. (RIBEIRO, 2006, pp. 1-2).

Joseph Kerman provocou discussões entre seus pares quando publicou: How we got into analysis and how to get out, de 1980. Kerman critica a eleição da música alemã como cânone, e estende suas críticas aos textos jornalísticos de crítica musical que considera superficiais. Observa que o critério de organicismo (a obra de arte compreendida como uma criatura viva), usado para lidar com a música instrumental alemã, pode não ser adequado para iluminar outras tradições musicais. Observa ainda que os músicos de tradição acadêmica não se esforçam para desenvolver modos alternativos de críticas em escalas mais amplas que as da análise.

Nicholas Cook, discutindo a relação entre Musicologia e Etnomusicologia, destaca a mudança de paradigmas da Musicologia provocada pela abertura para os estudos culturais. Observa criticamente que não se fizeram referências significativas aos trabalhos já desenvolvidos pelos etnomusicólogos, cuja abordagem sempre dialogou com as culturas sujeito de seu interesse em pesquisa.

Ele acrescenta:

Há um desenvolvimento particular na musicologia que eu vejo como crucial à sua convergência com a Etnomusicologia, e que teve crescente impulso desde o auge da "Nova" musicologia. Ele tem a ver com o significado musical, o assunto proibido que Susan McClary se empenhou para projetar no topo da agenda musicológica. (COOK, s/d, p.15)

John Shepherd elege o significado em música como foco de seu interesse. Em reflexão sobre a musicologia nos anos 1970 e 1980, compreende que as relações entre as realidades sociais são criadas por pessoas agindo juntas em condições sociais, políticas e culturais específicas, e o mesmo acontece com a música ali produzida. (SHEPHERD, 2003)

Analisar é preciso? Questiona Jean Molino:

Há, sem dúvida, uma experiência irredutível da música, mas esta experiência é impregnada de simbolismo, o que assegura a passagem natural da 
experiência para o discurso. A análise rompe com a experiência, mas ao mesmo tempo ela a prolonga; a análise é música continuada por outros meios. (MOLINO, 1989, p. 3).

O autor distingue um momento inicial no qual a análise era aplicada ao objetivo de guiar a recepção ou a produção de uma obra, mas o seu desenvolvimento criou um domínio autônomo, uma extensão do campo musical. Criou também, segundo ele, um corpo profissionalizado de especialistas, gêneros de análise e disputas entre eles, e comenta que "a análise está nas mãos de puros especialistas da análise pura, e é então natural que a análise se torne cada vez mais sistemática, abstrata, e podemos até falar, esotérica”.

Molino compreende que a análise apoia-se nos três princípios definidos por Descartes: “divisão, simplificação, enumeração" aplicados ao conhecimento da música. Ele entende que é natural analisar, que todo mundo analisa à sua maneira, seja por meio de um julgamento de gosto, ou por meio de um modelo formalizado. Comenta que inclusive em culturas mais primitivas $^{4}$ fazem-se análises, como comprovaram os trabalhos de Etnomusicólogos, como Hugo Zemp e Steven Feld. (MOLINO, 1989, p. 2)

Esta revisão breve da imensa discussão sobre os suportes teóricos e perspectivas para as pesquisas em música, apoia a inclusão de análises de alguns exemplos musicais do repertório ritual das Caixeiras do Divino. Acrescento arquivos sonoros para o conhecimento do som e diálogos mais fluidos com as partituras.

Antes de prosseguir, gostaria de acrescentar observações e reflexões que envolvem a presença das mulheres em distintos contextos sociais e musicais, com o objetivo de tecer informações que apoiam o universo desta pesquisa.

\section{Mulheres e música: experiências, conceitos, abordagens}

Maria Ignez Cruz Mello refletindo sobre o contexto brasileiro para a questão das Relações de Gênero e Musicologia, inclui em sua reflexão um episódio que embora se refira aos Estados Unidos, a autora considerou pertinente para a reflexão do lugar que as mulheres ocupam no universo da música. Trata-se de episódio relatado em trabalho da musicóloga Susane Cusick:

O Prof. Charles Seeger não aceitou a matrícula da compositora Ruth Crawford (de quem tornou-se marido tempos depois) em suas aulas e do mesmo modo, barrou sua candidatura para compor o quadro da New York

\footnotetext{
${ }^{4}$ Grifo meu
} 
Musicological Society. Sua exclusão deliberada foi, anos mais tarde, assumida por Seeger, pois ele acreditava que, com isso, estaria evitando que chamassem a então emergente musicologia de trabalho de mulher. (MELLO, 2007, p. 2)

Esse texto está aqui quase como epígrafe simbolizando, neste momento, um universo simbólico no qual se incluem interdições e ambivalências na relação com espaços de trabalho intelectuais e criativos, em música, feitos por mulheres.

Susan McClary, é musicóloga e foi contemporânea dos movimentos políticos de luta pelos direitos civis, direitos das mulheres, e do sentimento anti-governista de oposição à política externa dos EUA em relação ao Vietnam no final dos anos 60 e anos 70. Esse ambiente de luta possibilitou reflexões críticas, estruturadoras de sua ação profissional.

McClary relata que em 1968, quando começou a estudar musicologia, no currículo do curso não havia obras de mulheres e, ao questionar a escola, os alunos receberam como resposta que não haveria nenhuma musicista que fosse digna de ser lembrada. Ela relata que, com a ascensão do movimento de mulheres em 1970, um corajoso grupo de mulheres e homens musicólogos começou a árdua tarefa de dar visibilidade para um crescente número de musicistas que haviam sido relegadas a diferentes graus de obscuridade; Ruth Crowford Seeger, Lili Boulanger, Germaine Tailleferre, Ethel Smyth, Cecile Chaminadem, Amy Beach, Clara Wieck Schumann, Fanny Mendelssohn Hensel, Elizabeth-Claude Jacquet de La Guerre, dentre inúmeras outras; “cujas histórias permanecem não contadas”, ressalta.

McClary se inclui entre musicólogas feministas que sedimentam posições políticas críticas das estruturas sociais e destaca que, em um tempo em que os especialistas ameaçam fazer a música parecer inacessível para os não iniciados, a crítica das musicólogas feministas possibilitou a abertura para outros campos de estudo. Estabeleceu diálogos com a música integrada à vida cotidiana, com os estudos culturais e a crítica ao modelo androcêntrico de narrativa, observável pela linguagem usada pelos analistas. Um exemplo sempre referido denomina terminações cadenciais que ocorrem em tempos fortes de um trecho musical como masculinos, e aqueles que ocorrem em tempos fracos, femininos.

Cabe destacar que se torna cada vez mais difundido o uso da linguagem neutra para a escrita de textos científicos, e para citar um exemplo, a Association For Music Theory nos Estados Unidos se alinha a essa orientação em suas guidelines. Um resultado dos trabalhos de intelectuais feministas que, como McClary, tornam visível sua importância.

A autora define a abordagem da musicologia feminista de pesquisa como um lugar 
"por onde se pode conhecer e aprender sobre os ideais da nossa cultura em uma vasta gama de interesses vitais, incluindo sexo, sentimentos e o corpo". (McCLARY, 1994, pp. 365-366). É pertinente destacar que Susan McClary publicou Feminine Endings, obra na qual estabelece os parâmetros de sua abordagem, em 1991. Note-se que grandes e basilares textos em musicologia recebem traduções para português, mas, em 2011, os 20 anos desta sua obra foi comemorado com vários eventos, onde se destacou que até então Feminine Endings não havia sido traduzido para o espanhol e, em 2015, ainda não foi traduzido para o português.

McClary tem uma produção intelectual e musical criativa, vasta e comprometida em musicologia em diálogo com o feminismo. Seu foco é o desvendar as relações de gênero aí presentes, ampliando a compreensão do universo musical, também, em outros contextos. Diante dos desafios da diversidade de mulheres integrantes de diferentes classes sociais em sociedades racializadas, cabe identificar o feminismo de que fala Susan McClary. Trata-se daquele construído por pensadoras pertencentes a classe social hegemônica e branca, que desenvolveu um importante olhar crítico sobre a realidade das estruturas políticas e sociais, determinantes das relações de gênero.

A diversidade da História e as experiências étnico-raciais, de classes sociais, da diversidade sexual das mulheres, aportam diferentes perspectivas epistemológicas, e exigiram que a teoria crítica feminista as incluísse em seu corpo reflexivo e em sua ação política. $O$ conceito de gênero foi desenvolvido nesta perspectiva, e graças a ele foi possível ampliar e aprimorar a reflexão sobre as relações sociais entre homens e mulheres. E, em pulsão dinâmica, esse conceito segue em transformação diante do desenvolvimento das lutas sociais.

Andreza Andrade, em sua reflexão sobre o conceito de gênero, ressalta a grande importância de sua incorporação ao contexto político e intelectual, por romper parâmetros e suscitar críticas veementes aos modelos sociais consagrados pela hegemonia: pessoas brancas de classe média urbana e heterossexuais. (ANDRADE, 2009, p. 3)

O pensamento, do ponto de vista do gênero, representou uma saída do casulo da criatividade intelectual; uma luz para a re-fundamentação teórica do feminismo, ao criticar a concepção simplificadora do homem dominante versus a mulher dominada, nos informa. (ANDRADE, 2009, p. 5). O conceito de gênero revelou-se uma pertinente categoria de análise social e instrumento crítico da lógica essencialista, a qual mulheres e homens são categorias fixas que transcendem a história e, no mesmo grau de importância, a experiência. 
As dinâmicas dos estudos de gênero ampliaram a compreensão da complexidade trazida por um olhar sobre o corpo que articula reflexões sobre o sexo biológico e suas representações sociais, compreendendo-as em suas fronteiras fluidas como queer, transgêneros. E desse modo, questionando pretensões hegemônicas da permanência de identidades fixas, entre elas o conceito de mulher ou homem.

A dinâmica dos movimentos políticos e a História das mulheres seguem exigindo a construção de diálogos entre os conceitos de gênero, sexualidade, raça, classe; discussões nevrálgicas que lançam luz sobre as diferenças significativas entre as mulheres.

André Bueno em sua tese Palhaços da Cara Preta, de 2004, compreende que a representação de raça e suas manifestações artísticas populares no Brasil provêm, em grande parte, dos movimentos de população na antiguidade do mediterrâneo que construiu descendentes afro-árabes em Espanha e Portugal. Esse intenso movimento de população e trocas comerciais antecipou os intercâmbios atlânticos com povos africanos na condição de influentes comerciantes e, também, escravizados na condição de mercadorias.

Na Península Ibérica, as lendas mouriscas sobre tesouros alegadamente
escondidos se espalharam: 'tudo o que é misterioso e inexplicável vem do
tempo dos mouros ou está sob o poder de uma moura encantada'. Depois da
descoberta do tráfico de escravos no Atlântico, o feitiço das africanas
tornou-se um dado adquirido, tanto para viajantes e mercadores no ultramar,
como para um público mais alargado que conviveu com africanos na vida
diária na Metrópole. (PERRY 1990, apud BUENO 2004, pg. 27).

O trabalho de Mary Elizabeth Perry refere-se às margens da sociedade na Sevilha do século XVI e faz um recorte de classe destacando iniciativas econômicas de mulheres. A autora cita variados empreendimentos construídos ou herdados por mulheres casadas, viúvas e mulheres pobres. Seu trabalho mostra como algumas delas subverteram a ordem de gênero, usando uma variedade surpreendente de estratégias físicas, intelectuais e uma infinidade de articulações políticas. Afirma também que "já em meados do séc. XVI, a presença de africanas empenhadas em todo tipo de serviços em cidades como Lisboa e Sevilha era marcante" (PERRY, 1990, p. 17).

Bueno compreende que a passagem do séc. XV para o XVI ampliou o papel de mulheres africanas e mestiças como intermediárias e porta-vozes. Mas,

Das canetas dos autores célebres cujos escritos chegaram aos nossos dias correu muito pouca ou nenhuma tinta para dar voz e cara às mulheres que estavam muito mais próximas deles em suas digressões: as 'lavadeiras' e, sobretudo, as 'ladinas', a serventia doméstica. Afinal, a existência destas era 
um fato consumado. Tanto na África como na Península. (BUENO apud PANTOJA 2014, p. 27).

A historiografia, das relações Áfricas e Brasis com foco na visibilidade das mulheres na História, tem sido construída com empenho de pesquisadores(as) e o objetivo específico de ampliá-la para além das referências sempre ligadas à serventia doméstica. Em entrevista à FAPEMA durante o lançamento de seu livro, As Donas do Poder: economia e vida material de mulheres no Maranhão colonial (1755-1822), no início do ano de 2015. a historiadora e professora da UFMA, Marize de Campos sintetiza essas referencias acima citadas: "preguiçosas, incapazes, medrosas e passivas, circunscritas ao lar e para as quais a única via de felicidade era colocada no casamento e filhos e todas que escapavam a esse 'modelo ideal' eram mal vistas, julgadas como masculinas, loucas ou prostitutas".

Um crescente número de estudos ${ }^{5}$ sobre o poder das mulheres, têm demonstrado a amplitude dessas experiências na história econômica, visibilizando a presença de mulheres comerciantes, construtoras e ou gestoras de suas fortunas e famílias, em parceria, ou não, com seus maridos e filhos. Mulheres entre as quais se identificam negras, mestiças e brancas em distintos contextos, têm tido sua presença e importância conhecidas em papéis de comerciantes ativas, inclusive no tráfico negreiro.

Do ponto de vista político, a contemporaneidade mantém e aporta outros desafios para a compreensão da realidade das mulheres. Trago a palavra de mulheres negras e início com a paradigmática reflexão de Jurema Werneck, criadora e coordenadora da Ong Criola, no Rio de Janeiro, que desenvolve trabalhos de apoio e formação política com mulheres negras. Ao discutir a construção de uma epistemologia feminista, Werneck incorpora os paradigmas da produção coletiva. Declara que as ideias que estruturam seu pensamento são resultado de uma circulação dinâmica da qual não se identifica o início, mas que se entretece à compreensão das mulheres, criando comunidades de saber com fronteiras imprecisas. Werneck critica o encarceramento da dinâmica de construção do pensamento nos parâmetros do individualismo e da propriedade privada de conceitos e ideias. (WERNECK, 2010, p. 01)

“As mulheres negras não existem”, provoca ela. E desenvolve sua compreensão, observando que somos:

${ }^{5}$ Cf : Selma Pantoja (org.), Marize Helena de Campos, Vanda Lucia Praxedes. Philip J. Avik. 
o resultado de uma articulação de demandas históricas, políticas e culturais de enfrentamento das condições adversas estabelecidas pela hegemonia eurocêntrica ao longo dos séculos de escravidão, expropriação colonial, que se mantém na modernidade racializada e racista em que vivemos. (WERNECK, 2010, p. 10).

Desse modo, Werneck identifica a possibilidade de redução de "subjetividades históricas complexas às categorias identitárias fixas, fundadas em marcas fenotípicas”.

A filósofa fundadora e coordenadora-executiva do Geledés - Instituto da Mulher Negra em São Paulo -, Sueli Carneiro, reflete sobre a dinâmica histórica do movimento de mulheres, onde estão presentes as mulheres oriundas das classes médias e superiores da sociedade, que trouxeram para o movimento o capital político, social e intelectual de sua origem. Em Enegrecer o Feminismo, de 2010, Carneiro avalia que o atual movimento de mulheres negras no Brasil e América Latina, tem trazido para a cena política as contradições resultantes da articulação das variáveis de raça, classe e gênero, enegrecendo as reivindicações das mulheres, tornando-as mais representativas do conjunto das mulheres brasileiras, e feminizando as reivindicações do movimento negro.

Complexidades são visibilizadas pela articulação de vozes construídas por múltiplas experiências, que questionam toda pretensão de totalidade e homogeneidade dada por um conceito: feminismo. Considerado por este ponto de vista, aquele conceito torna-se distante demais das circunstâncias concretas enfrentadas pelas mulheres em qualquer tempo e espaço e leva ao reconhecimento de feminismos.

O diálogo entre esta discussão e as circunstâncias concretas enfrentadas pelas Caixeiras é um tema para ser pesquisado e compreendido. Sacerdotisas dos cultos festivos para o Divino Espírito Santo, as Caixeiras são, em geral, mulheres negras; pretas ou pardas, clientela de Terreiros, moradoras em Quilombos, periferias, comumente pertencentes à classe social de baixa renda.

Não construíram, ainda, uma organização política que as congregue e represente, embora sejam frequentes entre elas, as reflexões, críticas, questionamentos e propostas sobre como os poderes públicos poderiam apoia-las depois de uma vida inteira como Caixeiras, cumprindo seu papel. Várias entrevistas sobre este tema estão no documentário Umas Mulheres que dão no Couro: As Caixeiras do Divino no Maranhão, já referido neste trabalho.

Nos últimos 15 anos, com a expansão das politica de fomento aos festejos pelas políticas públicas estaduais de apoio ao turismo cultural, passaram a questionar o seu ganho na relação com o valor recebido pelos(as) donos(as) de festa como fomento aos festejos. 
Embora seja conhecida a importância de sua presença nos festejos, também não há políticas públicas de apoio a elas em reconhecimento à particularidade de seu ofício. Caixeiras não têm direito a aposentadorias que as apoiem em sua velhice depois de longa trajetória de vida vinculada estreitamente à condução de festejos.

Essas mulheres são as protagonistas de um universo devocional, musical e ritual que em sua performance tocam toques complexos em um roteiro ritual sofisticado e detalhado que possui grande poder de coesão das comunidades que os realizam.

Elas têm mantido vivo seu universo pela construção, guarda de conhecimentos e pelo preparo de outras Caixeiras, sem que o tempo de início e de fim dessa prática sejam conhecidos. Sua presença, diversidade e continuidade são indicativos de uma experiência mais extensa e importante no universo da atividade de mulheres. A música propiciatória, cuja profundidade é construída e desvendada um pouco a cada tempo.

D. Raimunda Soares, conhecida como Raimunda Boró, Caixeira de Alcântara que em 2000, tinha 92 anos:

- Desde quando as Caixeiras existem na Festa?

- Ô minha filha, quando cheguei já achei...

\section{Sobre a etnografia dos festejos}

As informações de caráter etnográfico que aqui descrevem os cultos festivos do Divino, foram extraídas de minha dissertação para o Programa de Pós-Graduação em História pela PUC--SP: Umas Mulheres que dão no couro - As Caixeiras do Divino no Maranhão.

Foram agregadas às informações construídas pela pesquisa para o mestrado, outras durante o processo de produção, posterior, de um documentário e um livro que receberam o mesmo nome da dissertação. O material sonoro e audiovisual assim construído integra as informações etnográficas utilizadas neste trabalho.

Escolho informar esta fonte e não citar cada trecho referenciando minha dissertação anterior. Muitos dados são construídos por entrevistas constantes do documentário.

O objetivo daquela primeira dissertação era trazer, aos olhos de outros universos diferentes do das Caixeiras, a experiência paradigmática desenvolvida por essas mulheres; a 
condução, com o canto e toques de tambores, dos cultos festivos para o Espírito Santo, no estado do Maranhão.

Cursei a disciplina de Etnomusicologia e técnicas de gravação em campo com Tiago de Oliveira Pinto, na Universidade de São Paulo, e assisti a palestras e cursos oferecidos em São Paulo pelo Etnomusicólogo congolês professor na Universidade de Kent, Kazadi Wa Mukuna. Presenciei gravações em campo com a Associação Cultural Cachuera! e fiz meus próprios experimentos em Festas de Nossa Senhora do Rosário na comunidade dos Arturos em Contagem, Minas Gerais, e Folias de Reis em Anápolis, Goiás. Mais familiarizada com os trabalhos de campo, me senti segura para fazer a etnografia de festejos do Divino. Fui a campo no Maranhão e gravei a música propiciatória dos rituais, conhecendo do processo a presença das Caixeiras. A Associação Cultural Cachuera! Por intermédio do seu criador e presidente, o etnomusicólogo Paulo Dias, me emprestou um equipamento criativo perfeito para situações como aquela. Bom microfone com cabo, proteção contra o vento feita com cano de pvc envolto e protegido com meia fina marrom de nylon. Uma vara de boom feita com cabos de vassoura, com uma criativa e funcional possibilidade de extensão. Eu havia comprado um bom gravador DAT Sony anos antes, quando a paixão pela etnografia e os trabalhos de campo começaram a se mostrar para mim.

Além das gravações áudio para a pesquisa em História, quatro anos depois, mais 100 horas de material audiovisual foram gerados pela produção do documentário com apoio do Programa Petrobras Cultural ao qual já me referi. São também gravações do repertório ritual e entrevistas qualitativas em profundidade.

Como mulher e tocando percussão em grupos de mulheres, eu procurava conhecer as razões da interdição dos tambores rituais para todas nós. Escolhi trabalhar com os recursos da história oral em imersão no universo desses cultos festivos. Essa escolha foi oportuna para visibilizar as experiências, as formas de produção de conhecimentos, os processos de ensino/aprendizagem no universo da oralidade, no qual essas mulheres, principalmente, mas também muitos homens, criam.

Alessandro Portelli em sua vasta experiência em trabalhar com a história oral, destaca o pluralismo resultante dessa prática que trata das visões particulares da verdade, permitindo a construção do conhecimento por várias abordagens. Lembra que não se deve esperar a "rigorosa verdade", pois a pessoa que dá seu depoimento o faz a partir do filtro de sua memória e de sua subjetividade. Esta se destaca quando a depoente escolhe relatar ou não determinados fatos ou sentimentos. $\mathrm{O}$ teor de um depoimento pode variar de acordo com a 
qualidade da relação de confiança estabelecida entre a pesquisadora e as pessoas entrevistadas, pois uma exposição expõe ao mesmo tempo o tema e a expositora. A memória não é aquilo de que lembramos, é o que somos. (PORTELLI, 1997, p. 26).

As leituras em História oral e a experiência de trabalhar com depoimentos orais, me ensinaram que os processos de construção da História, em seus diferentes níveis, estão em estreito diálogo com a subjetividade e em diálogo com enorme variedade de circunstâncias. É uma fabulação, na expressão do cineasta Eduardo Coutinho, que empregou em todo o seu trabalho esse método de revelar a força das subjetividades: entrevistas.

Conversei com muitas Caixeiras gravando entrevistas para conhecer sua experiência. Pude conviver estreitamente com um grupo em Alcântara elas em um cotidiano de esmolar sob um sol brilhante e muito quente. Grandes Histórias relatam e desvendam modos de vida em comunidades que se organizam no cuidado com filhos e trabalhos assumidos, para que elas pudessem viajar durante meses a pé, tocando Caixa, cantando e esmolando para o Divino e a Santa Crôa.

As entrevistas buscavam a profundidade da experiência e as subjetividades construíam as narrativas dessas mulheres, protagonistas da própria História. Cada relato desvelava criatividade e competência artística em poesia do improviso, em música de tradição oral, tudo em estreita relação com sua devoção e responsabilidade na conquista de recursos materiais para a realização dos festejos.

Exponho a seguir algumas informações sobre a organização da minha pesquisa anterior e sua dissertação, com o objetivo de destacar diferenças entre o trabalho atual e o primeiro movimento na direção da pesquisa no ano de 2000.

O primeiro capítulo, descreveu os festejos na Casa Fanti Ashanti, um importante Terreiro de Tambor de Mina e Candomblé em São Luís. Festejo que foi o catalizador de informações da forma particular dos festejos nos Terreiros, que compartilham significados e constroem diálogos com um culto de matriz católica. No mesmo capítulo descrevi antigas sequências excluídas dos roteiros rituais pela ampliação e complexidade das cidades. Uma realidade que dificulta cortejos a pé, dado o crescimento das distâncias, da violência e mudanças na relação com o tempo e modos de vida de populações que acolheram essas manifestações.

O Capitulo 2 foi dedicado às Caixeiras na Festa em Alcântara, onde as Caixeiras estavam presentes em longos trajetos cotidianos sob sol forte em cortejos para esmolar e também de visitas rituais entre membros do Império. Longos cortejos também são realizados 
para a entrega de alimentos (carnes e pão) a moradoras da periferia da cidade. Um costume que remete aos roteiros açorianos, sempre referidos como matriz dessa Festa. Esta entrega de alimentos é denominada Bodo, e tem como objetivo a possibilidade de uma imensa refeição coletiva, embora cada qual em sua casa naquela noite de sábado, véspera do Domingo de Pentecostes, possam comer juntos.

O Capítulo 3, As Caixeiras e seu fazer musical, dedicou-se a tecer a rede de temas estruturadores do seu universo ritual, organizados em blocos com depoimentos e relatos de experiências sobre cada um dos temas daquela rede. Expressão musical desse contato cultural, traz uma reflexão sobre sincretismos. Em Ritmos, toques, descrição do repertório musical. No agrado, o pagamento estão as relações com donas e donos de festas. Hierarquia das Caixeiras traz os relatos sobre o aprendizado e o dom de cantar para o Divino. Temas transversais, construindo um mosaico orgânico pertinente para a compreensão da experiência dessas mulheres, cuja existência é marcada pela independência, autonomia e assertividade reveladas em entrevistas sobre a sua experiência particular e em relatos sobre as suas antecessoras e ancestrais.

A Festa mantém sua importância ainda que os modos de vida das Caixeiras contemporâneas sejam pautados por realidades diferentes daquelas Caixeiras antigas, cujas vidas foram estruturadas pela prática e presença nos festejos, cortejos e viagens para tirar jóia. Agora, estas mulheres precisam equilibrar sua presença nos festejos e em outros trabalhos cujos horários orientam a organização do seu tempo, reduzindo sua flexibilidade.

\section{Objetivos e métodos neste segundo movimento: Os caminhos se fazem ao caminhar.}

Este estudo sobre as Caixeiras e sua música alinha-se aos estudos e pesquisas que visam dar visibilidade às mulheres como sujeitos históricos, participantes de grandes e pequenos acontecimentos da história humana e também agregar documentação sobre o fazer musical e a música das Caixeiras do Divino. Desse modo, ele amplia o próprio campo de informações disponíveis sobre a cultura e a presença das mulheres fazendo música e ocupando lugares de poder em festejos de culturas tradicionais.

O método foi construído pelas realidades confrontadas pela pesquisa a cada momento, e reflete as necessidades identificadas no processo. Buscando olhar para uma construção 
musical diaspórica em sua forma contemporânea. Escolhi integrar algumas análises musicais pelo caminho das partituras e diálogo com o contexto. O canto e a percussão dos tambores, marcadores rítmicos privilegiados, estruturam música das Caixeiras e por isso, escolho os Toques nas Caixas, como eixo de reflexão, com o apoio das análises.

Para o presente trabalho, escolhi a Casa Fanti Ashanti. E esta é uma escolha do coração, cérebro e história. As Caixeiras desta Casa foram minhas mestras nos Toques de Caixa ainda em S. Paulo. Eu já tinha sido aprovada no Mestrado em História com o projeto de estudar o universo do Divino no Maranhão, pela presença das mulheres na sua liderança, quando a sincronicidade da vida as levou a oferecer uma oficina em São Paulo.

Foi quase por acaso. Dindinha e Zezé foram visitar sua irmã Graça em São Paulo e uma percussionista, Daniela Aquino, pediu a elas que mostrassem sua música. E daí surgiu a oficina de Caixas na Associação Cultural Cachuera! cuja sede estava em construção. Tijolos e sacos de cimento eram afastados e à noite durante uma semana, acontecia a oficina.

Quisemos saber como aquela música que aprendíamos se unia à festa e elas se dispuseram a mostrar. Alunas levaram suas crianças que formaram um Império do Divino. Montamos um altar com tronos para eles se sentarem, fizemos um círculo com as cadeiras e tocamos o que tínhamos aprendido no processo. Essa foi a primeira festa, que completou 16 anos no último maio.

Poucos meses depois fui ao Maranhão fazer o trabalho de campo para o meu mestrado em São Luís e Alcântara. Elas me receberam em sua casa até que encontrei um lugar para ficar. Neste processo, conheci a Casa Fanti Ashanti e o seu dirigente, o Babalorixá Euclides Menezes Ferreira, homem de sabedoria profunda e cujo Encantado Antônio Luís Corre Beirada é o dono da festa do Divino naquela Casa.

Neste momento, de retomada da pesquisa, escolho a música dessa Casa cujo repertório foi parcialmente gravado no estúdio da Associação Cultural Cachuera! em uma conexão simbólica e histórica com o trabalho que tenho desenvolvido.

Soma-se a estas razões, o fato de que os roteiros rituais dos cultos festivos para o Divino realizado nos terreiros se assemelham em grandes linhas e se distinguem de acordo com os Terreiros que os realizam. Em todos há abertura de um espaço tempo para a chegada do Divino. Um levantamento de Mastro, cortejos de visitas mútuas entre os membros da Corte Imperial, cortejos para buscar o Mastro, cortejos para uma missa, derrubamento do Mastro, passamento das posses para os Impérios do ano seguinte, e fechamento da Tribuna. Um 
repertório musical em todo o processo é compartilhado, recriado, ou permanece em locais e casas onde é praticado embora as trocas e criações sejam a regra.

Desse modo, busquei gravações do CD Caixeiras da Casa Fanti-Ashanti Tocam e Cantam para o Divino, Vol. 5 da coleção Documentos Sonoros Brasileiros - Acervo Cachuera!, em parceria com o Instituto Cultural Itaú.

Incluí, também, a faixa Alvorada que encerra Levantamento do Mastro, do repertório das Caixeiras de Alcântara, toque e cantiga à qual se referiu D. Margarida Maria de Araújo ao descrever o repertório das festas da cidade. A inclusão desta faixa atendeu à necessidade de compreender os sentidos atribuídos por D. Margarida a esta cantiga. Sentidos que revelam informações que a análise objetiva não conseguiria captar.

A compreensão da profundidade desse fazer musical exige transversalidade metodológica na construção do seu contexto. Desse modo, se incluem aportes de discussões étnico-raciais, de gênero, da História, de conceitos de diáspora, em diálogo com estruturas musicais em um esforço de compreensão das relações que o fazer musical dessas mulheres e sua música constroem.

A referência aos toques e cantos em uníssono do repertório das Caixeiras levou ao título: Pulsando Junto: A música diaspórica das Caixeiras do Divino.

Estes objetivos e caminhos metodológicos se orientam pelas necessidades que os sujeitos do estudo apresentam. E para minha própria compreensão busquei conhecer as discussões internas à Etnomusicologia, organizadas aqui na Introdução deste trabalho Métodos, Conceitos e Abordagens. Ainda na Introdução, apresentei a origem dos dados etnográficos, suporte para a construção do contexto em diálogo com as análises musicais. A reflexão sobre Mulheres e pesquisa em música explorou redes de conceitos e informações que envolvem universos onde mulheres constroem seus espaços na gestão de sua vida.

O Capítulo 1 informa dados recentes sobre a popularidade destes cultos festivos para o Divino no Maranhão, alguns dados históricos sobre a Festa, as conexões entre universos simbólicos dos Terreiros e os cultos para o Divino. Apresenta, também, as Caixeiras e seu instrumento. O Capítulo 2 apresenta conceitos de diáspora agregados a dados geográficos e históricos para a compreensão da mobilidade da população e difusão dos festejos. Também estão ali os diálogos que esses estabelecem com o universo dos terreiros onde são celebrados. No Capítulo 3, estão as análises da música em diálogo com o contexto em que ela é 
produzida. Anexei um CD com as gravações das faixas de foram referência para as partituras, para que o som desta música possa ser conhecido, e não apenas a sua representação gráfica.

As Considerações Finais não se identificam como conclusões, mas um passo adiante em meio a muitas trilhas por percorrer. 


\section{CAPÍTULO 1}

Meu Divino Esprito Santo

Esta vai a seu louvor

Não há ouro, não há prata

Que mereça seu valor

(verso do repertório das Caixeiras)

\section{1 - Alguns dados contemporâneos sobre a popularidade das Festas do}

\section{Divino}

A Festa está em constante diálogo com a dinâmica dos Terreiros e cidades que a realizam, e não se configuram costume antigo que não existem mais, e que precisam ser resgatados. Ao contrário disso, essa capacidade de diálogo com a contemporaneidade constrói a História, conectando o passado ao presente pelo viés da presença dessas mulheres, iluminando a relação simbiótica entre memória e História.

Alguns dados sobre a Festa e seus festejos dão compreensibilidade ao contexto contemporâneo. Trago um trabalho do pesquisador e antropólogo português, João Leal, especialista em Festas do Divino que tem desenvolvido pesquisas sobre a Festa no estado do Maranhão. João Leal analisou dados de registro de Festas em um Cadastro realizado pelo Centro de Cultura Popular Domingos Vieira Filho, órgão da Secretaria de Cultura do Estado do Maranhão. Esse refere-se às inscrições dos Festejos que solicitam o apoio financeiro do governo do estado, como parte da política de apoio ao turismo cultural. Suas informações iluminam a dimensão da existência destas Festas do Divino em São Luís e em outras localidades no Maranhão. Nas palavras de João Leal;

A comparação com Santa Catarina, um dos estados brasileiros onde as Festas do Divino têm uma expressão mais relevante, é esclarecedora. Lá, no conjunto do estado, o número de festas é de cerca de 70, enquanto só em São Luís, estamos a falar de perto de 80 festas. Se admitirmos que no estado do Maranhão o número total de festas poderá andar - de acordo com as estimativas mais correntes, em cerca de 150, estamos a falar do Maranhão como uma das áreas de maior concentração de Festas do Divino Espírito Santo ao longo da sua geografia atlântica (formada por Portugal Continental, Açores, Madeira, Brasil, EUA, Bermuda e Canadá). E estamos também a falar da cidade de São Luís como o território urbano onde as festas apresentam maior densidade. (LEAL, 2012, p. 4)

E acrescenta: 
A centralidade dos terreiros de religiões afro-brasileiras - particularmente dos terreiros de Tambor de Mina na realização das Festas do Divino da cidade de São Luís é outro ponto já sublinhado pela literatura disponível e que é confirmado pelos dados do cadastro. Trata-se de uma particularidade das Festas do Divino de São Luís, cuja importância deve ser sublinhada”. (Idem).

Os resultados apresentados por essa sistematização de informações traduzem em números um movimento ascendente de criação de Festejos do Divino em São Luís que chega aos 79 existentes no ano de 2012. Dentre eles, 61 são realizados em terreiros de cultos afro-brasileiros.

Esses dados apontam, também, para uma dinâmica de expansão da Festa do Divino em São Luís, com destaque para a relação particular com o calendário dos terreiros. Sua relação com o universo simbólico das religiões de matriz africana ali existentes ainda é tema aberto a mais pesquisas.

Avalia-se, da mesma forma, que o aumento do número de festas pode ser atribuído ao apoio financeiro pelas políticas públicas, já referido. Esse apoio estimularia pessoas devotas do Divino a ampliarem para a complexidade e sofisticação dos Festejos as celebrações simplificadas, como as Salvas.

O tempo dos festejos do Divino se inicia no dia de Pentecostes e segue por todo o ano, até o carnaval do ano seguinte. Esse tempo estendido durante o ano para a realização dos Festejos é atribuído à falta de Caixeiras Régias para conduzi-los.

As Caixeiras relatam que têm conduzido vários Festejos simultaneamente, com Festeiros(as) buscando-os(as) e levando-os(as) de volta a diferentes Festejos, para conduzirem momentos rituais em diferentes lugares durante um mesmo dia.

\section{2 - Um pouco da história da festa e conexões entre universos simbólicos.}

As Festas do Divino e seus Festejos são rituais do catolicismo popular compreendido como um espaço religioso de práticas de diferentes origens, com variados significados construídos e atribuídos por seus praticantes. É uma celebração do Espírito Santo que, por 
ocasião de Pentecostes ${ }^{6}$, desce do céu sobre os apóstolos de Cristo sob a forma de línguas de fogo, episódio descrito no livro Atos dos Apóstolos, capítulo 2, no Novo Testamento da Bíblia.

O pesquisador português, Moisés Espírito Santo, se contrapõe a essa versão sobre origem e significado dessa festa e desenvolve sua argumentação apresentando vasta referência bibliográfica e iconográfica. Ele afirma que o culto do Divino é uma festa judaica, ou um ritual popular cripto-judaico ${ }^{7}$ de celebração e rememoração periódica da Aliança de Deus com o povo judeu; aliança simbolizada pela entrega das Tábuas da Lei, com os Dez Mandamentos de Deus ao patriarca Moisés, no Monte Sinai. (ESPÍRITO SANTO, 1988, p. 114).

Uma versão sempre referida às origens do culto ao Divino, afirma que ele teria sido criado pela Rainha Santa, Isabel de Aragão que se casou com D. Diniz o então Rei de Portugal, em 1282 e vivia em Alenquer, hoje Distrito de Lisboa. Mas Moisés Espírito Santo afirma que a rainha Isabel de Aragão teria sido profundamente identificada com a causa dos judeus, a quem denominava "meus judeus". Através de um decreto, ela teria instituído o culto do Divino, possibilitando sua identificação com um culto cristão, legitimando-o aos olhos da Igreja Católica.

O autor entende que a popularidade do culto do Divino não poderia ter sido construída através do decreto de uma Rainha, mesmo sendo santa. Ele já existia. Acrescenta que a rainha Isabel de Aragão foi canonizada num processo que, embora cheio de contradições, foi real, e teria sido organizado por cristãos novos. Sua canonização teria tido o objetivo de abrir uma possibilidade de culto a Ester, rainha santa no Antigo Testamento.

Antonio Brágio, pesquisador português em sua obra As Confrarias Medievais do Espírito Santo, Paradigmas das Misericórdias, investiga os paradigmas que apoiam a existência das Casas de Misericórdia, encontra-os frequentemente relacionados, ou sucedâneos às confrarias e hospitais do Espírito Santo. Mas a ambos, culto ao Espírito Santo e Casas de Misericórdia, não consegue datar ou encontrar a origem. E inicia sua exposição:

Não há documentos de instituição da confraria do Espírito Santo de Benavente, nem da feitura de seus estatutos. Se a data de uma verba, segundo a qual D. Plagia mandava cantar anualmente uma missa por uma herdade que legara à Confraria do Espírito Santo da mesma vila, é do mês de Agosto de 1272, da era de César, que corresponde a 1234 da era cristã, sabido é que nesta data já existia em Benevente a dita confraria sem que se saiba desde quando.

\footnotetext{
${ }^{6}$ Pentecostes é uma palavra grega para quinquagésimo dia. No antigo testamento da bíblia, designa a Festa da Messe celebrada pelos judeus sete semanas depois da Páscoa, que celebra a aliança de Deus com o povo judeu. No novo testamento celebra a nova aliança entre Jesus Cristo e a população de cristãos.

${ }^{7}$ Referencia à prática secreta do judaísmo quando oprimido oficialmente.
} 
O autor considera dados obtidos por outros pesquisadores, dentre eles, Rui de Azevedo, o qual, apoiando-se em documentos dos compromissos de confraria, pressupõe que na vila de Alenquer tenha sido fundada, em data mais remota, anterior ao ano de Cristo de 1217, a confraria do Espírito Santo com os estatutos semelhantes àqueles de Benevente. $\mathrm{O}$ argumento de Rui de Azevedo se apoia na existência anterior de uma ermida com a mesma invocação, onde se celebrava com toda a pompa as festas do Império do Espírito Santo.

Antonio Brágio acrescenta;

Embora D. Diniz e Santa Isabel tenham a fama de instituidores da festa do Império do Espírito Santo, Rui de Azevedo é de parecer que eles foram apenas os reformadores de festividade mais antiga, cuja gênese se descobre numa cláusula de compromisso da confraria que manda fazer todos os anos um bodo aos pobres no dia do Espírito Santo.

Outro olhar sobre a relação entre Isabel de Alenquer e o culto do Divino, afirma que a rainha teria dado continuidade a um culto iniciado pelas ideias de Joaquim de Fiori, um monge da ordem dos Cisterciences que viveu de 1135 a 1202, e cujas ideias haviam se difundido na Europa. Tido como um dos grandes responsáveis pelo crescimento do conjunto de ideias que originou o Franciscanismo na Europa, De Fiori criticava a ação da igreja medieval, violenta e perseguidora de riquezas que tomava para si, e defendia uma igreja mais ligada aos pobres. Ligado a esses princípios, o Tempo do Divino seria um tempo de abundância, alegria, liberdade, contemplação, amor, respeito aos velhos, um tempo de luz, de perfeição no entendimento, tempo de amizade.

A antropóloga Maria Lucia Montes, em texto para o encarte do segundo CD das Caixeiras da Casa Fanti Ashanti Caixeiras da Família Menezes Cantam para o Divino, reflete sobre o repertório de uma Festa de Pentecostes, na qual estão presentes cantigas em louvor à Senhora Santana, Santíssima Trindade, Nossa Senhora da Guia, Bom Jesus da Cana Verde, Bom Jesus da Coluna. Além destes, também está presente o Bendito de Hortelã, considerado poderoso e fino, e cuja sequência de execução não comporta erros sob pena de graves incidentes ocorrerem na casa. O Bendito de Hortelã descreve o padecimento de Cristo e constitui o repertório para o ritual de Abrir e Fechar a Tribuna, o espaço-tempo sagrado, local físico e simbólico para a realização dos Festejos.

Montes também se refere, neste texto citado, à relação entre a Festa do Divino e as Festas da Misericórdia:

... com espanto, descobrimos que a celebração maranhense do Espírito Santo se filia a uma tradição bem mais arcaica, que se une em suas raízes às festas 
da Misericórdia. As Irmandades da Misericórdia são conhecidas desde o século XII na Itália e, em Portugal, desde os tempos da rainha Dona Leonor de Aviz, irmã de Dom Manuel, em fins do século XV. E elas se filiam diretamente às formas de devoção então correntes nas Irmandades do Espírito Santo. (MONTES, 2011, p. 6)

Esta Festa adquiriu, no contexto brasileiro, grande popularidade e diversidade nas formas de celebração. Por isso, José Bonifácio de Andrada e Silva a aconselhar os soberanos portugueses a se autodenominarem Imperadores e não Reis, em função da anterior popularidade do culto ao Divino.

Os festejos realizados nos Terreiros são uma grande particularidade do Divino Maranhense, aliada à presença das Suas Sacerdotisas, as Caixeiras. Essas afirmações se adensam com o, já citado trabalho, de João Leal que em 2012 que evidenciou a escala crescente dessa celebração pelos Terreiros e o aumento de sua popularidade.

Considerado por seus devotos como um ritual cristão por celebrar o Divino Espírito Santo, uma das três pessoas da Trindade Divina, este culto adquire formas particulares nos lugares onde é realizado. Em todos eles, o Divino catalisa simbolismos característicos da finitude humana em diálogo com a imortalidade do poder do Divino, que nunca desaparece, e não importa quem o represente; mulheres, homens e crianças podem ser seus representantes na Festa do Maranhão.

Nos festejos do Divino no Maranhão ou em todos os lugares cuja festa foi inspirada naqueles, a representação do Divino é feita por um Império formado por crianças. Embora o(a) festeiro(a) ou dono(a) de festa seja uma pessoa adulta.

A Côrte ou os Impérios costuma ser formada pelo Imperador, Imperatriz, Mordomo Régio, Mordoma Régia, às vezes Mordomo Mór e Mordoma Mór, os três anjos ${ }^{8}$ e apoiados pelo(a) Mestre-Sala. A esta estrutura podem se juntar outros personagens e estas são escolhas que envolvem a cosmogonia da casa ou a escolha do(a) dono(a) de festa.

Os Festejos obedecem a roteiros que envolvem internamente aos Terreiros, a abertura de um espaço-tempo, uma dimensão sagrada cuja compreensão se diferencia da sacralidade dos Terreiros que festejam o Divino. Este tema será melhor desenvolvido na discussão sobre a Abertura da Tribuna, no Capítulo 3 deste trabalho.

\footnotetext{
${ }^{8}$ os mistérios: fé, esperança e caridade N.A
} 
O levantamento de um Mastro em cujo cimo está o Mastaréu, um estandarte do Divino costuma ser a abertura do festejo para o público. Muitos cortejos, uma missa, almoço e jantar rituais, nos quais as crianças comem em pé e as Caixeiras cantam para elas. Cantorias das Caixeiras também em frente aos Impérios e ao Divino. Cantos e toques também para a cerimônia de passamento das posses quando as crianças são despojadas dos símbolos de poder associados aos cargos que ocupam. Essas hierofanias, as representações do sagrado são entregues neste momento às outras que ocuparão os mesmos cargos no ano seguinte. A Imperatriz perde seus símbolos para a Mordoma Régia e o mesmo acontece com todos os cargos. Essa cerimonia costuma provocar o choro das crianças e forma a compreensão da impermanência para todas as pessoas que participam do festejo.

Elas são despidas dos símbolos do poder dado pelos cargos que ocuparam com versos cantados pelas Caixeiras. Com música as Caixeiras lembram a elas que o Divino lhes dará um bom futuro, boa sorte para ela e sua família, boa cabeça para os estudos, lembram a elas que quem foi rei será sempre majestade. Um elaborado ritual com muitas camadas de significados.

Nos Terreiros essa representação é sempre feita por um menino e uma menina representando um casal. Destaque-se que em Alcântara e em Paço do Lumiar, no Maranhão, diferentemente da maioria dos lugares nos quais se cultua o Divino, as mulheres podem ser representantes de Seu poder. Ali há uma alternância formalmente estabelecida, na qual em um ano a festa é liderada por uma Imperatriz, quando o Império é composto por Mordoma Régia e Mordoma Mor. Do mesmo modo, no ano em que a Festa tem a liderança de um Imperador, o Império é composto por meninos.

Em festejos do Divino fora do Maranhão, a representação de Seu poder é feita por um Imperador. Pode-se encontrar, às vezes, sua esposa a seu lado, em posição derivada de sua relação de casamento com o Imperador.

Pelos rituais do culto ao Divino, seus devotos vivenciam, junto com o Império, um ciclo de ascensão, posse e perda de cargos e poder, ressaltando a impermanência e a transformação. Essa repetição cíclica e re-atualização ritual são dadas pela sua relevância para o grupo social, pela renovação dos seus significados para os devotos. Embora ocupe um espaço temporário nos Terreiros, um espaço que se abre e se fecha com a Tribuna, a Festa do Divino tem e segue construindo um espaço de grande importância. Sergio Ferretti, antropólogo pesquisador do universo afro-brasileiro no Maranhão, compreende que ao simbolizar a posse de elementos culturais europeus, essa Festa teria sido considerada capaz de conferir poder ao universo afrodescendente dos terreiros. (FERRETTI, 1985). 
Nos processos continuados de construção e consolidação dos espaços sociais de aceitação e respeitabilidade, de poder e de liberdade para existir, essas Casas forjaram alianças com pessoas influentes, políticos, intelectuais, que, entrando pela porta aberta pela festa, tornaram-se aliadas com relações consolidadas por amizades e troca de favores. Objetos sagrados de culto foram encontrados em coleções particulares de arte africana ou de matriz africana, doados por antigas dirigentes da Casa das Minas, por exemplo. Os casamentos também estão entre as alianças possíveis na construção de um lugar de respeitabilidade e defesa das perseguições às quais os Terreiros sempre estiveram sujeitos.

As reflexões de Michel de Certeau oferecem uma contribuição para essa discussão, com seus conceitos de estratégia que denominam a ação dos dominadores e seus projetos necessariamente universalizantes. Em contraposição, tática é o caminho usado pelas classes em posição subalterna, a partir de onde incorporam e ressignificam costumes e conceitos que pertencem originariamente às classes dominantes (CERTEAU, 1996). Essa reflexão nos auxilia a compreender as várias hipóteses sobre o lugar de onde partiram os conteúdos para a incorporação orgânica das festas do Divino pelos terreiros no Maranhão. Os simbolismos atribuídos pelos Terreiros ao Divino Espírito Santo, divindade representada pelo(a) pombo(a) branco(a), estabelecem uma diversidade de relações entre diferentes universos culturais, um tema que merece pesquisas.

Martha Abreu, por sugestão de Mary Karash, compreende que a pombinha do Divino (e a representação do pássaro de prata) pode ter sido reconhecida por escravizados de origem centro africana, como semelhante, em significado e forma, ao que naquela região era atribuído ao pássaro: o limite entre o dia e a noite, o limite entre a vida e a morte (ABREU, 1999).

Em seu artigo De africano a afro-brasileiro: etnia, identidade, religião, Reginaldo Prandi detalha informações sobre a diversidade de povos aos quais pertenciam os africanos escravizados e levados para o Maranhão.

Nagôs ou Iorubás são nomes genéricos dados aos africanos escravizados, mas que compreendem vários povos de língua e cultura iorubá, entre os quais os oyó, ijexá, ketu, ijebu, egbá, ifé, oxogbô etc... Os fon-jejes, que agregam os fon-jejes-daomeanos e os mahi, entre outros. Os haussás, famosos, mesmo na Bahia, por sua civilização islamizada, mais outros grupos que tiveram importância menor na formação de nossa cultura, como os grúncis, tapas, mandingos, fântis, achântis e outros não significativos para nossa história. Frequentemente tais grupos foram chamados simplesmente de minas. (PRANDI, 2000, pp. 52-65).

No Madredeus, bairro da região central de São Luís está a Casa das Minas, um tradicional Terreiro de Tambor de Mina (religião afro-brasileira desenvolvida no Maranhão). 
De acordo com o antropólogo Sergio Ferretti pesquisador com intenso trabalho e ligação com esta casa, os festejos para o Divino Espírito Santo são realizados ali desde o final do século XIX.

Segundo D. Celeste, a festa do Divino foi iniciada, lá, por sua dona, Nochê Sepazim, que pertence a uma das famílias de Voduns ${ }^{9}$, do panteão da Casa. Essa princesa era carregada por mãe Hosana, a terceira chefe, que dirigiu a casa em inícios do século, até falecer em 1914, sucedida por mãe Andresa. (FERRETTI, 1985, pp. 168-169).

Sergio Ferreti informa no trabalho acima citado que as caixas, os tambores tocados pelas Caixeiras, são batizadas com nomes como Açucena, Florzinha, Prenda do Ano, Soberana, dentre outros. Em entrevista perguntei a D. Jacy, a Caixeira Régia da festa do Divino na Casa das Minas, se aqueles nomes dados às Caixas, seriam uma referência aos encantados que fazem parte da cosmogonia da Casa e ela respondeu:

"Não! Não! Na casa das Minas a festa do Espírito Santo é de Espírito Santo! Nada com pajelança! Tem as suas divisões; Umbanda e Espírito Santo! Na Casa das Minas, eu enxergo assim, não tem essa mistura!"

Também em São Luís, a Casa Fanti Ashanti, Terreiro que pratica o Candomblé e o Tambor de Mina e é dirigida pelo Babalorixá Euclides Meneses Ferreira, realiza o Festejo do Divino desde 1958. Em entrevista, ele ensinou que o festejo do Divino é realizado na Casa pela identidade e paralelismo estabelecidos entre o Espírito Santo e Ifá, divindade importante e respeitada na Nigéria, lugar de origem dos cultos que no Brasil tomou a forma do Candomblé.

Pai Euclides ressalta que Ifá é o dono do Jogo do Opelê, de caráter divinatório e que, obedecendo aos princípios religiosos dos Nagôs, é focado no número 3 (três) e contém o princípio chamado de Etá. Euclides acrescenta que para o povo jêje de língua Fon, a divindade responsável pela adivinhação é Fá. Os jêje são originários do Benim, antigo Daomé, de onde se origina o culto que, no Brasil, toma a forma de Tambor de Mina.

Esclarece ainda que, para essas culturas, essas divindades são mensageiras das palavras dos Deuses dirigidas aos homens e interpretadas por aqueles que conhecem a ciência e as artes divinatórias. Além de as conhecerem, possuem a permissão ritual e hierárquica para exercê-las: no Brasil, os zeladores de santo em suas diferentes nomenclaturas. Em sua fala:

\footnotetext{
${ }^{9}$ Em seu livro Querebentan de Zomadonu, A etnografia da Casa das Minas, de 1985, publicado pela Edufma Sergio Ferreti descreve cada uma das famílias, que estruturam o panteão da Casa das Minas, dando a conhecer a história e dinâmicas daquela Casa.
} 
Ifá ou Fá é todo um sistema oracular daquilo que a gente quer saber e que, na palavra dos africanos, equivale ao Divino Espírito Santo, que é do catolicismo.

Muitos trabalhos têm sido desenvolvidos para a compreensão dessa realidade de paralelismo de cultos, sincretismos, mas aqui não são objeto de análise. Aqui apresento a identidade entre as divindades de matriz africana e o Espírito Santo como a entende Pai Euclides. O Divino como mensageiro.

Não sei, que de católico não pego nada. Mas talvez sim, porque ele não é o mensageiro de Deus? Não foi ele que veio anunciar a vinda de Cristo? Ele é uma espécie de adivinho porque ninguém viu Deus onipotente.

Note-se que ao final da festa do Divino da Casa Fanti Ashanti, fazem-se três dias de Toque de Candomblé onde o grande homenageado é Oxaguian, divindade do panteão africano cultuado pelo Candomblé que tem o pombo branco entre os símbolos que o identificam. Em seguida, quatro dias de Toques de Tambor de Mina.

Uma diversidade de razões e cosmogonias estão na construção do universo religioso de cada Terreiro, mas as sequências rituais nos cultos festivos para o Divino que realizam, possuem grande semelhança entre si. Em todos eles, serão abertos espaços físicos e simbólicos, incorporando à rotina das Casas outra cosmogonia que inclui Caixeiras na condução dos rituais.

\section{3 - E quem são as Caixeiras do Divino?}

São as Sacerdotisas dos cultos ao Divino Espírito Santo, que elas conduzem com o canto e percussão de tambores, as caixas. O nome Caixeira relaciona-as à sua função de tocar a caixa, mas seu ser é inseparável do canto, da potência de sua expressão vocal, da afinação, da dimensão de seu repertório, dos conhecimentos das sequências rituais. Todos esses são atributos que fazem com que uma Caixeira seja considerada e respeitada pelas outras, pela sua irmandade. Há quem diga que "quem toca caixa é Caixeira", mas as contradições estão presentes. D. Alzira Reis Pires refere-se à existência de Caixeiras que ajudam; tocam caixa mas não cantam, ou cantam mas não improvisam:

"Elas tocam Caixa, mais num é assim, uma pessoa pra enfrentá tudo como manda a lei." 
A identidade dessas mulheres costuma ser estreitamente associada à de Caixeiras. Numa visita à Agrovila do Cajueiro, na região de Alcântara, perguntei: - Onde mora dona Margarida? E um transeunte me respondeu: - A Caixeira? É naquela casa ali...

São costumeiramente mulheres negras; pretas ou pardas, com idades frequentemente superiores a quarenta anos, como ressalta Sergio Ferretti (1995), pertencentes a classe social de baixa renda e clientela de Terreiros. Tocam Caixa por devoção, e nesse processo, trabalham. Nesse trabalho sedimentam uma identidade respeitada que inclui seu ganho ou agrado, denominações para seu pagamento; sua sobrevivência e a de sua família.

Relacionam-se com os festejos de diversas formas; como parte de grupos de Caixeiras, estruturados por anos de convivência, ou como filhas de santo dos Terreiros, como convidadas, visitantes. Algumas Caixeiras relatam no documentário Umas Mulheres que dão no Couro: As Caixeiras do Divino no Maranhão, que se pode também chegar a uma festa onde não é conhecida, aproximar-se do círculo formado pelo grupo que está tocando em frente ao altar do Divino, botar um verso pedindo licença e ser recebida. O grupo pode ceder uma caixa para que ela possa juntar-se às outras cantando e tocando.

Há uma liderança que se aproxima do conceito de hierarquia, mas o transcende. A líder é a Caixeira-Régia, que tem o apoio e parceria da Caixeira-Mor. As outras ajudam, embora todas sejam responsáveis pela música em todos os momentos, e todas elas tenham espaço para tirar cantigas durante os rituais. Observa-se uma estrutura de cooperação. É preciso muitas Caixeiras para que o Festejo seja brilhante, e possam fazer longas cantorias. É desejado que todas possam botar cantigas e é esperado que todas criem versos, improvisando no diálogo com o tema proposto para o canto naquele momento.

A sua identidade de Caixeiras nos Terreiros permanece enquanto permanece o Festejo. Não é vivenciada no dia a dia. Está presente durante os processos de preparação e realização dos Festejos do Divino. Se são também filhas de Santo da Casa, participam cotidianamente de sua dinâmica, sem que o fato de serem Caixeiras lhes conceda privilégios de qualquer natureza. Pode acontecer que as Caixeiras responsáveis por funções importantes no Festejo não pertençam à comunidade da casa, e cheguem para conduzir a festa. Há grupos de Caixeiras que cuidam de festejos e estabelecem relações duradouras com a Casa e os(as) donos(as) de festa.

O roteiro ritual possui repertório específico e com sua música constante durante a festa elas estabelecem e mantêm aberto uma comunicação com o Divino Espírito Santo, em um 
diálogo explicitado pelo discurso metricamente estruturado em quadras com 4 versos de 7 sílabas cada um com rimas na segunda e quarta linhas. Essa é a referência para a criação, improviso e o reconhecimento de perfeita métrica poética e também referência de sua desobediência, quando reconhecem ou botam versos sem rima: "pé quebrado", como elas definem. A prosódia do texto cantado se estrutura pelo toque, e desse modo, a métrica fica variável.

O conhecimento musical e ritual das Caixeiras e sua forma de transmissão transcendem a dimensão que o liga ao rito, constrói relações sociais, engendra um corpus de Caixeiras. Este é um grupo restrito, com regras próprias para reconhecimento, desafio, inclusão e rejeição de suas participantes. É uma irmandade não formalmente constituída. $\mathrm{O}$ código de conduta, as exigências do conhecimento de suas participantes, é claro, difundido e respeitado.

O corpus de Caixeiras nem sempre forma grupos fixos, nem todas se conhecem ou se reconhecem, nem todas vivem na mesma cidade, na mesma região. Em reuniões entre diferentes grupos de distintas regiões, observa-se estranhamentos, comparações de repertórios, críticas mútuas aos modos de cantar, tocar e conduzir os ritos. E todas as diferenças possíveis não apagam as grandes identidades entre as suas práticas musicais e rituais e o fato de reconhecerem-se como Caixeiras participantes de uma mesma comunidade, uma irmandade de mulheres, uma comunidade imaginada, como nos estimula a reflexão de Benedict Anderson (ANDERSON, 1991).

Comunidade imaginada é um conceito criado no diálogo com a noção de nação e se expandiu para a compreensão de outros grupos que do mesmo modo que uma nação, não se baseiam em relações face a face. São comunidades que pressupõem um laço imaginado. Trago aqui alguns depoimentos que contribuem para essa reflexão. D. Alzira Reis Pires fala de seu mal-estar quando não está tocando Caixa em alguma festa junto com outras Caixeiras:

Quando eu chego em casa, parece mentira. É todo o tempo com meu corpo doído, uma coisa e outra, mas minha filha, eu sonho todo dia cantando Caixa! Parece mentira, eu disse aqui pra Euclides: - Pra mim parece que eu to despedindo, que eu vou é morrer... porque eu canto, e criança vem e diz; mamãe, mamãe, mamãe! Parece que to doida... porque eu canto, sabe porque? Por causa da Invocação, a fé e a alegria que eu tenho de tá tocando Caixa...

Ana Benedita Ferreira, a Anica, Caixeira antiga no Festejo na cidade de Alcântara, compadecida com as Caixeiras que não podem mais tocar, fala de sua dor: 
"Meu coração chora de ver pessoas que me ensinou não poder mais tocar caixa. E nós se acabando todas... num tem mais Caixeira, a festa fica só na igreja. E aí fica muito descontrolado porque a festa na igreja não é nunca como o batuque e a música acumpanhano".

Os grupos de Caixeiras costumam se definir pelo corpus que toca em uma festa. $\mathrm{O}$ encontro constante constrói a intimidade e convites para outras festas. A dimensão da amizade, do companheirismo, das disputas e demarcação dos espaços, cujo campo é o universo da festa, engendram sua irmandade. Na vida dessas mulheres, a importância do pertencimento à irmandade de Caixeiras e a força de tocar caixa e cantar coletivamente no culto ao Divino, é muito grande.

O lamento pela perda dessa vivência, o poder contido na responsabilidade pela condução da Festa, da performance no espaço público, se evidencia na fala de Raimunda (Boró) Soares, que foi uma lendária Caixeira-Mór com voz poderosa, na Festa em Alcântara. Seu lamento pela perda dos espaços de performance nos cortejos da cidade nos faz compreender o lugar que a música ocupou na plenitude de sua vida.

Ah! Nesse tempo eu tinha era voz... Voz! Quando os outro tava armuçano, ou fazendo quarqué coisa dentro de sua casa, que ouvia o batuque do Império e ricunhicia minha voiz, vinha pra janela pra escutar eu cantar... Hoje em dia não posso mais cantar, não tenho dente, não tenho saúde...vivo contrariada. (...) É que aquilo, eu tenho choque no meu coração! Alembrar quem já foi Raimunda, no tempo de Jesus!

O festejo na cidade de Alcântara foi vivenciado pelo escritor e cronista Carlos de Lima, seu frequentador assíduo, desde 1961 até sua morte em 2011. Lima relatou em crônicas, as sequências dos rituais e o clima das Folias do Divino daquela cidade, e descreve as Caixeiras do lugar.

...são quase sempre lavadeiras que pouco trabalham pelo ofício visto que as funções do Divino só lhes deixam livres três meses por ano. Geralmente idosas, causa admiração sua resistência á fadiga, nas longas caminhadas e constantes vigílias de festa, além dos inevitáveis ataques de maleita. (LIMA, 1972, p 27)

O festejo da cidade de Alcântara sempre recrutou as Caixeiras entre as mulheres moradoras das comunidades quilombolas da região ${ }^{10}$. Essas mulheres costumavam viajar em grupo, a pé durante meses por ano, tirando joia para a Santa Crôa, viabilizando materialmente a festa e, do mesmo modo, o fortalecimento das redes de relações entre o

\footnotetext{
${ }^{10}$ Grande número dessas comunidades quilombolas foram remanejadas por desapropriação da área onde viveram desde sempre, desde a formação de quilombos. Essas áreas foram incorporadas à área da Base de Lançamento de Foguetes de Alcântara.
} 
Divino e seus devotos, entre o festeiro ou a festeira daquele ano e seus amigos, parentes, aliados políticos que viviam distantes da cidade.

Note-se que essas viagens eram investimentos de grande monta organizadas pelo Imperador ou Imperatriz do Divino, responsável pela realização do festejo naquele ano. Para que as viagens pudessem acontecer, contratavam-se as Caixeiras cujo número era variável em relação direta com suas posses e capacidade de investimento.

Um grande cortejo era indício de um grande investimento relacionado a uma Festa importante; era um agregador de redes sociais formadas por moradores que viviam longe da Sede do município. Tratava-se de investimento, do qual se esperava um retorno financeiro suficiente para a realização de uma grande Festa. Para isso, recrutavam várias Caixeiras, em particular aquelas com capacidade de improviso para o diálogo com moradores das regiões por onde andariam.

Durante estas viagens, liderando o cortejo pela estrada, ia o Bandeireiro carregando o estandarte vermelho aberto ao vento, a bandeira do Divino. Em seguida, vinham as Caixeiras tocando, os animais carregadores das cargas com as roupas, redes e as joias, que eram arrecadadas no trajeto. Arrecadavam-se sacos de farinha, açúcar, carnes secas, sal, pequenos e grandes animais, conforme o poder de quem doava e o argumento de quem pedia a joia. Também faziam parte dos cortejos homens encarregados dos cuidados com esses animais. O líder desses tinha o nome de Vicente, um nome genérico dado a quem ocupasse essa posição.

Nos anos 80 as políticas públicas para o turismo no estado do Maranhão passaram a incluir o fomento às Festas populares, e a Festa do Divino em Alcântara começou a ser fortemente apoiada. Desde então, as viagens para tirar jóia, realizadas com a liderança das Caixeiras, tiveram sua importância reduzida como investimento, e aos poucos deixaram de ser realizadas.

Atualmente essas viagens só acontecem em casos de promessa feita pela(o) festeiro(a) que inclua o tiramento de jóia. Nesse caso tem um caráter simbólico e não de real apoio financeiro para o Festejo e desse modo restringe-se a uma área reduzida e por pouco tempo.

Outra prática para arrecadação de donativos que conheci na Festa em Alcântara; esmolar ou ciganar. Essa saída é feita em cortejo pela cidade. Representantes do Império levando a Santa Croa; a coroa encimada pelo Pombo branco, pode ter ou não o 
acompanhamento de Caixeiras; o batuque. Caso elas não estejam presentes, denomina-se escoteiro ao cortejo para esmolar que sai sem a música das Caixas ou banda de música.

Em Paço do Lumiar, um dos municípios da Ilha de São Luís, construções de uma estrutura das Festas ocupa espaços físicos na cidade. Em Periá na região dos Lençóis Maranhenses, também há espaços físicos construídos para os cultos festivos do Divino e usados apenas na ocasião dos Festejos.

A realidade dessas Festas em Alcântara, Periá e Paço do Lumiar, para citar as que conheci, tinham Festejos realizados com recursos captados pelas Caixeiras em suas viagens para pedir jóia.

A captação dos recursos pelos terreiros também se apoiou em uma rede de relações para pedir donativos e apoios para sua Festa que costuma/costumava acontecer na forma de cartas dirigidas à rede de relações da Casa que por sua vez as redistribuem, multiplicando o apoio para suas redes de relações pessoais e familiares. Do mesmo modo que as viagens, essas redes fortalecem as relações entre amigos e apoiadores da Festa, devotos ou admiradores dos cultos festivos ao Divino, bem como as articulações políticas dos Festeiros.

Parte da identidade coletiva das Caixeiras foi construída pelo seu papel de tirar joia em viagens por outras partes da cidade, ou ainda por outras cidades, tocando caixa e cantando. Essas viagens não fazem parte da experiência das Caixeiras na contemporaneidade e aquelas que as viveram, relatam estas histórias como um tempo de rompimento com o cotidiano, aberto ao inusitado, um campo pleno de acontecimentos e possibilidades.

Os moradores, nos interiores, relatam a passagem desses grupos de Caixeiras com alegria, pelas brincadeiras que traziam para seus lugares e casas. Há lugares onde ainda esperam e recebem os, agora raros, grupo de Caixeiras que passam por suas casas para refeições, cantorias ou pousos.

O passado tem sido o tempo do verbo para falar das Folias com relatos significativos que se referem a 50, 60 anos atrás ou ainda mais tempo. As Caixeiras que ainda realizam essas Folias para pedir joia não saem mais a pé, têm seu trajeto facilitado por carros particulares e lotações. As estradas, agora movimentadas, trouxeram perigo de violências e medo. Aliado a essas razões, as folias perderam seu papel hegemônico no financiamento dos festejos. 
Um relato de D. Marcelina nos apresenta um pouco da realidade dessas viagens e seus trajetos:

- Dezoito anos! Todo ano! Saía do Canto, terra de Marly Sarney, mãe de Roseane ${ }^{l 1}$, De lá começava e vinha; saltava no Pau Deitado, de lá para o Timbuba, de lá para Canavieiras, Sítio do Apicum, e de lá para o Mojó, e Ribamar...

Interrompo:

- Tudo a pé? Não tinha ônibus?

E ela responde:

- A pé! E Caixeira lá pode andar de ônibus? Mas pra lá não tinha nada!

E prossegue:

Saía de Ribamar para Mirititiua, passava pela subestação e ia no Lugar dos Índios. De lá para Rio Grande, de lá para o Cururuca, de lá para Pindaí, Mercês, Suzana, Rio de São João, Pissarreira, Estrada da Boa Viagem, aí voltava de novo pra pista. Aí ganhava Laranjal, Quinta, Mata, Barraca, Mata Grande, Mata Pequena, e seguia pra Santana, Tororama, Baiacú, Tagipuru do Lindoso, de lá, Tagipuru do Procópio, daí Santa Maria, de lá Guarapiranga. Aí voltávamos, entravamos para Juçatuba, Santa Maria Mãe dos Homens, daí Bom Jardim, Cruzeiro, Santa Bárbara... Daí São Bernardo, Forquilha. Aquela igreja de Senhora Santana na Forquilha era de Taipa, e isso era 1950. Quando chegava na Forquilha, nós ia correr Maioba. Aqueles lugarzinho que tinha pra lá, se transformou só em Maioba. Tudo! Maioba do Bacuritiba, Maioba do Vassoral, Maioba do Genipapeiro... ora era água doce, ora água salgada, assim que era. Ás vezes atravessava de canoa, e andava quilômetros a pé.

Importante ressaltar que os roteiros das folias eram orientados por certa rivalidade entre as localidades visitadas. Heidimar Marques, morador antigo de Alcântara que conhece bem essas práticas, conta que os pedidos de joia necessitavam de uma permissão dos vigários das localidades, preservando-se os espaços de domínio sobre os lugares passíveis de controle por uma paróquia ou município.

Essas práticas fortalecem o conjunto de distinções, privilegiando e aprofundando as noções de pertencimento ao grupo, ou a uma localidade, ressaltam as noções de diferenciação com as outras, criando e acentuando as rivalidades. Relatos nos incluem nessa realidade dos encontros entre grupos de Caixeiras que expõem suas rivalidades e disputam espaços. A arena

\footnotetext{
${ }^{11}$ A então Governadora do estado do Maranhão.
} 
da disputa é a festa e as armas, os improvisos em versos. A Caixeira, Ana Pereira Dias, a Santinha, relata sua experiência:

Quando a gente se encontra um batuque com outro, e eu sei jogar um verso pra outra, que se souber vortar pra mim, nós tamos garradas, e aí nós vamos batucar! (...)uma vez nós fomos aqui pro São Bento, e quando nós chegamos lá eles disseram: - Tem uma muito boazona, ali e tal, e aquela gente lá, e elas; [refere-se às suas companheiras] andavam só se escondendo lá pra ver se num garrava, e eu disse logo; - Vamos ver quem é que prende uns os outro nos verso pra nós se sortá logo?

Sentiu-se desafiada com a presença de uma grande cantora que sabia improvisar, uma repentista. Autoconfiante e animada pelas possibilidades abertas pelo desafio público, sentase para cantar, acompanhada de seu grupo.

Nós fomos sentadinha lá, e a bichinha foi correndo, e eu fui cantando pra ela, e ela foi embora, e eu fui cantando e ela foi embora, e fui cantando até que ela caiu fora!, Quer dizer que ela não firmou comigo, se ela tivesse firmado ela tinha ficado... mas ela caiu fora, ela não ficou ...

A outra "não firmou", não resistiu e não conseguiu responder com precisão aos versos propostos por Santinha, saindo da roda como perdedora. Orgulhosa, justifica sua ação;

É que tem uma que quer ser assim presunçosa porque sabe, e outra num sabe, e ela quer se jogar de ser melhor que outra. E aí ela vem com aquele negócio de despique pra meu lado e é asneira camarada vir com esse negócio de despique, vamos levar tudo numa boa que nós... Se sê caso de ser de manso nós vamos, se sê de brabo nós vamos, se sê de moleza nós vamos! $\mathrm{E}$ eu num posso butar nela que eu não sei, mas é difícil ela me agarrar também, porque graças a deus, abaixo do céu eu sei me livrar...

O desafio exige capacidade de improviso e há Caixeiras que sabem improvisar, tocando, cantando e dialogando em quadras, com o tema sobre o qual se fala e há outras que não têm esse conhecimento.

É grande a diversidade de formas e tempo de aproximação de mulheres com o universo da música para o Divino. Há Caixeiras que começaram a participar dos festejos aos 8 , 10 anos de idade, carregando bandeirinhas, outras que são filhas de Caixeiras e ouvem esta música desde o corpo de sua mãe e relatam sua presença em festas desde crianças e já tocando. Outras ainda, começaram muito mais tarde, motivadas pelo desejo de aprender a tocar, cantar e se juntar àqueles grupos que elas admiravam e despertavam seu desejo de tomar parte neles. 


\section{4 - Paralelos que a história aponta: mulheres tocando nos Festejos dos Açores e do Maranhão}

A presença das mulheres fazendo música em Festejos do Divino encontra um elemento de diálogo com a Festa dos Açores. Aqui temos uma informação de 1903. Uma quadra com versos cantados nas Alvoradas. Manuel Breda Simões informa que foi recolhida em 1903 na Ilha das Flores, no Arquipélago dos Açores. Ali temos a fala de mulheres em várias quadras com estrutura de Romance cantado nas ruas durante as Mudanças ou Peditórios de Irmandade; o que conhecemos no Brasil, no Maranhão, como Joias.

Fui eu ter com El-Rei
Que m'as mandou pagar,
El-Rei por ser eu mulher,

Não me quis escutar...

(SIMÕES, 1987, p. 28-29).

Breda Simões pesquisador dos cultos do Divino, identifica e destaca a presença das Alumiações, rituais de acender velas, iluminando o Trono, como nos Açores se denomina o Altar do Divino. O autor destaca que essas cerimônias são realizadas durante todos os sábados que precedem as sete domingas, as sete semanas que se iniciam na Páscoa e vão até o domingo de Pentecostes. Note-se que este é o tempo reconhecido, em muitos Festejos no Maranhão, como o intervalo de tempo entre a Aberturas das Tribunas e o dia da Festa: 49 dias. Repito aqui que Pentecostes é palavra grega para quinquagésimo dia.

As informações dessas práticas aproximam as referencias de matriz judaica, aqui representadas por números, práticas como o acendimento das velas por 7 semanas em espaços privados, àquelas dos rituais para o Divino, como o identificam vários autores, entre eles Moisés Espírito Santo em Matrizes Orientais da Religião Popular Portuguesa, trabalho já referido neste trabalho.

Simões (1987) descreve os festejos nos Açores, quando: “cometem abusos, cantando cantos profanos, toques de violas. Canta-se a Alvorada acompanhada a tambor, ao Espírito Santo".

E se refere à presença de mulheres. 
São as mulheres e raparigas quem canta nas Alumiações, convidando-se para regente aquela que melhor sabe improvisar. Saúdam aos visitantes por meio de cantigas, principalmente ás pessoas de distinção. As pessoas honradas com esses cumprimentos, fazem ofertas em dinheiro, que ás vezes é destinado às luzes da Coroa, ou às próprias cantoras. (Ibid., p 29. )

Simões ressalta que, se os foliões cantam, o produto da cantoria se reverte em seu exclusivo proveito, mas se o fazem as mulheres, todo o dinheiro é lançado na taça da Coroa, depois de novas quadras de elogio e gratidão.

O autor faz referência à presença e ao acompanhamento de Tambor, mas não explicita se são tocados por essas mulheres que cantam, ou por outras pessoas. Certamente, trata-se de um claro ponto de contato com as Caixeiras além do fato de cantarem improvisando. Esse fato é apontado por Simões como um dos atributos que definem a Regente do grupo citado. Identificamos nas Festas realizadas no Maranhão a presença das Caixeiras, e a Caixeira Régia em particular, como improvisadoras em versos, em diferentes momentos do culto festivo ali realizado.

Festeiro de Espírito Santo
Eu não posso mais cantar
Tenha dó de sua Caixeira
Me dê ao menos um guaraná

Eu não gosto de cerveja

Eu não gosto de licor

Só tomo Coca-Cola

Morena da minha cor

(improviso durante o festejo)

As Caixeiras presentes à festa botaram esses versos e, é claro, foram atendidas em uma tarde quente. E, à semelhança das mulheres citadas por Simões, o que quer que ganhem participando da festa recebe o nome de agrado, e nunca pagamento pelas funções que exercem.

Não encontrei outra referência à existência dessas mulheres às quais se refere Manuel Breda Simões. Essa descontinuidade da presença de mulheres fazendo a música 
propiciatória nas Festas do Divino em outros estados no Brasil ${ }^{12}$, em Portugal continental, no Arquipélago dos Açores, no Canadá, nos Estados Unidos, nas Ilhas Canárias, numa geografia ampliada constantemente pelas migrações de Açorianos, provoca inevitáveis e impertinentes questões.

Santa Catarina, Goiás, São Paulo, Minas Gerais, para citar alguns, e também na geografia atlântica que inclui o Arquipélago dos Açores, partes do Canadá e dos Estados Unidos, os cultos festivos do Divino são os homens os responsáveis pela condução dos cultos festivos e cortejos devocionais, os giros de folias. As formações instrumentais utilizadas incluem violões, violas, violinos, pandeiros, uma caixa.

As mulheres se ocupam da preparação dos espaços, dos alimentos, refeições rituais. Ao lado da família recebem os Foliões que chegam a cavalo e ritualmente pedem licença para entrar.

Os Foliões são orientados por um conjunto de regras que inclui a interdição ao contato com as mulheres durante o tempo dos Festejos. Em Goiás, por exemplo, os Foliões não podem voltar para suas casas ou se relacionar sexualmente enquanto não terminar o giro da Folia, dentre outras práticas resultantes de um conjunto de crenças que se difundiu com a Festa.

Seu discurso devocional tem muitas semelhanças com aquele das Caixeiras do ponto de vista da métrica poética. Quadras com versos com sete silabas com rimas na segunda e quarta linhas, no entanto encontram-se cantigas com versos com onze sílabas.

O repertório das Caixeiras se orienta por versos e cantigas para o Divino, o Pombo Branco, Bom Jesus da Cana Verde, Bom Jesus da Coluna. A presença e ciclo aparentes do sol, e da lua. Também se incluem os diálogos e encontros com Maria, mãe de Jesus, varrendo a varanda pela manhã. Observa-se a presença de mulheres velhas, a avó, como Sant'Ana, a mãe de Maria e avó do Menino Jesus.

Nesses circuitos de fontes vivas, modificações dos temas se evidenciam também no encontro com a Encantaria Maranhense. Daí resultam muitos versos sobre o Pombo Pedrês, ou ainda "a Família de Espírito Santo é uma família real”. Uma família da qual participam o Sabiá, a Rosa Branca e o Beija Flor. O conceito de família presente no universo dos Voduns e

\footnotetext{
${ }^{12}$ Há festejos no Rio de Janeiro e em São Paulo, por exemplo, liderados por maranhenses que migraram com suas festas e seus costumes.
} 
Encantados é incorporado ao repertório de alguns festejos, construindo uma compreensão particular de Espírito Santo a quem o cristianismo não concede família.

\section{5 - Um tambor: a Caixa do Divino.}

Essas mulheres são Caixeiras por tocarem Caixas - tambores do ponto de vista organológico. Instrumentos musicais de percussão da família dos membranofones tocados com baquetas ${ }^{13}$. Do ponto de vista da Organologia, uma caixa pode ser relacionada aos tambores militares europeus e, também, a tambores africanos bi-membranofones tocados com baquetas.

A Figura 1 é uma fotografia do Festejo no quilombo de Santa Rosa dos Pretos, em Itapecuru Mirim no Maranhão. Num momento de descanso, as Caixeiras se reúnem para cantar improvisando versos. Identificam-se as caixas sobre o seu colo, posição usual quando cantam sentadas durante o ritual. A líder D. Severina Pires Belfort, canta e veste azul. 


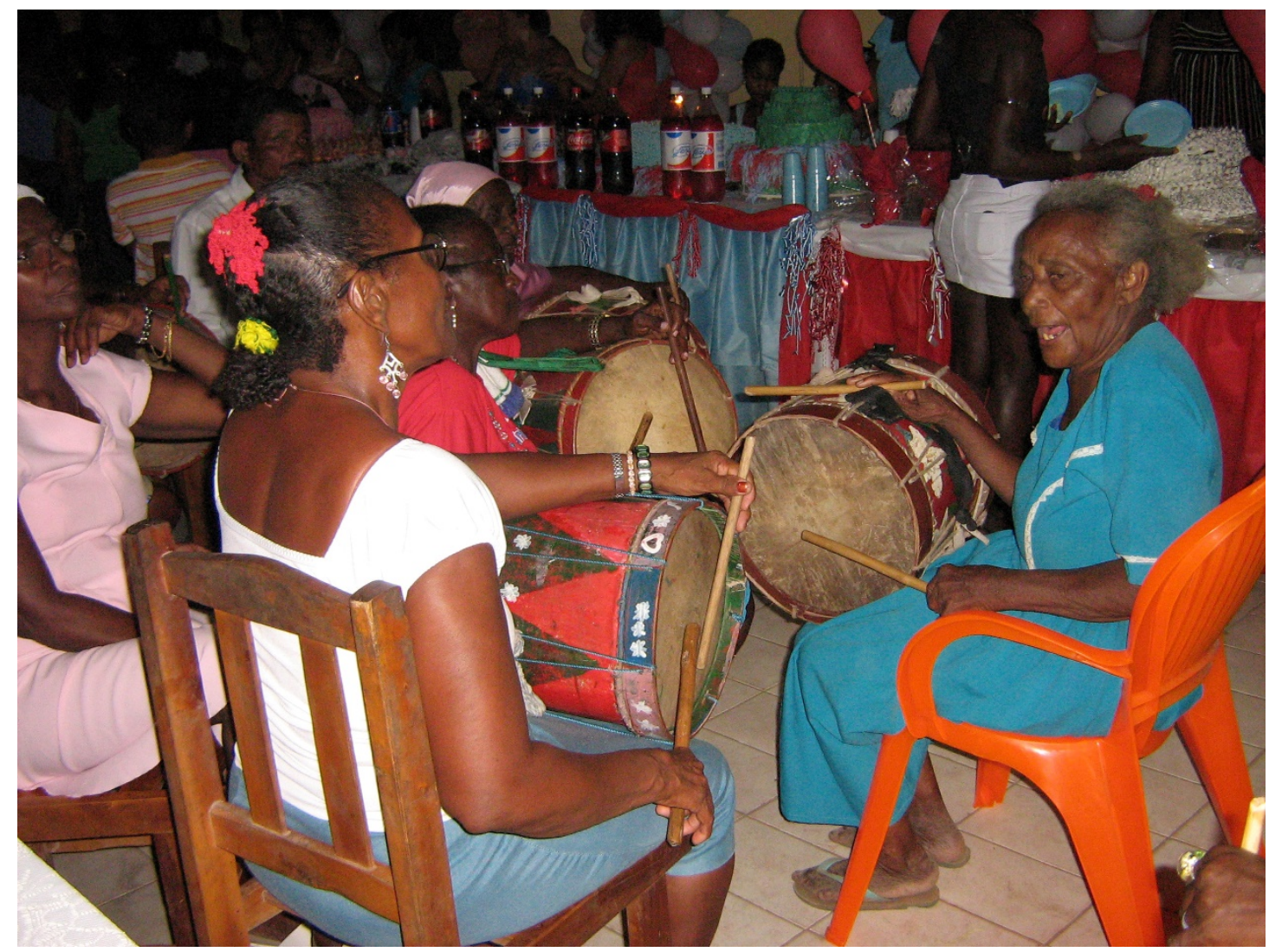

Figura 1 - Caixeiras do quilombo Santa Rosa dos Pretos em festejo na comunidade.

As Caixas são tambores cilíndricos, com diâmetro que varia entre 30 e $35 \mathrm{~cm}$, com altura de 40 a $45 \mathrm{~cm}$. Essas medidas são apenas uma referência de seu tamanho usado nestes festejos. As caixas estão incorporadas a muitos cultos festivos tradicionais no Brasil.

O corpo do instrumento, como é chamada sua caixa de ressonância, pode ser de madeira ou de metal. Os de madeira podem ser feitos de madeira escavada ou construídos com compensados vergados progressivamente com vapor e mantidos em estruturas que irão conformá-los à envergadura e tamanho desejados. Os corpos de metal são construídos usando-se latas cilíndricas, originalmente usadas para embalagem de óleo combustível. Há ainda caixas feitas de madeira escavada com fogo e esculpidas com ferramentas de corte, em um trabalho artístico minucioso e paciente.

A caixa tem sua superfície coberta com pele animal, geralmente de cabra ou outra fêmea pelas qualidades de flexibilidade e resistência inatas, à qual ela deve seu som, ou melhor, o timbre de sua voz. Essa pele recebe tratamento especial, estendida e curtida ao sol e, quando pronta, é molhada, tornando-se maleável. É costume a raspagem dos pelos que a recobrem, mas a manutenção de parte da sua pelagem permite o timbre grave que é o som esperado desse instrumento. 
Para fixação da pele, usam-se aros em madeira ou ferro, com espessura de aproximadamente 1,5 centímetro, sobre o qual se estica o couro ainda úmido, costurando-o nas suas bordas, formando uma superfície. Usa-se uma dessas superfícies de cada lado do corpo do tambor para fechá-lo. Sobre esses aros apoia-se outro em ambos lados, com 5 centímetros de altura, em média, que funciona como suporte para amarração e afinação do instrumento. Nesse aro são presas cordas de nylon ou algodão, cuja função é fazer a amarração que permitirá afinar e manter afinado o instrumento. "os bordão tem que ficar bem estirado". Se a pele do instrumento não está bem estendida e assim mantida pela amarração, o instrumento não fala a sua voz, não emite seu som.

Um tambor, como um corpo, precisa de um espaço para soltar ar, sob pena de não produzir som ou que este tenha um excesso de reverberação. Com essa função, há um furo lateral no corpo da Caixa. Paralela à sua superfície, na parte inferior, colocam-se linhas de nylon que podem conter cernes de penas de aves, contas de rosário, miçangas, pequenos objetos que vibram quando a pele é percutida. A sonoridade produzida com esse artifício, inclui a vibração proporcionada por esses artefatos que compõem o som ${ }^{14}$ buscado para esse instrumento, nessa festa. Para tocar, usam-se duas baquetas rígidas, e há Caixeiras que as preferem com pesos diferentes.

As Caixas costumam ser pintadas. Às vezes a pintura inclui os símbolos do Divino, a Coroa e a Pomba, outras vezes, com uma só cor viva - branco, vermelho, azul, verde - ou várias cores em listas, triângulos ou losangos. Algumas vezes as Caixas são batizadas e recebem nomes. É comum que Caixeiras antigas e famosas não possuam seu próprio instrumento, ainda que suas preferências entre os instrumentos disponíveis sejam respeitadas; essa caixa é de fulana!. As Caixeiras costumam tocar em caixas pertencentes à casa da Festa, mas há lugares e Caixeiras que possuem seus instrumentos, construídos com ajuda dos filhos, amigas ou amigos. Raramente são comprados em mercado de instrumentos.

As Caixeiras estabelecem uma relação de identidade com o seu instrumento, como pude ver numa cena quando acompanhava uma Caixeira Régia a um festejo e a porta principal da casa estava fechada. Ainda preparavam a Tribuna e os Tronos onde se sentam os Impérios.

\footnotetext{
${ }^{14} \mathrm{O}$ som com essas características é encontrado em vários instrumentos de matriz africana e faz parte de uma concepção de música e sonoridade que inclui as vibrações provocadas por esses objetos. Como o berimbau, por exemplo, inclui o som com vibrações causadas pelo uso da moeda ou pedrinha tocando a corda percutida. Diferente da música que busca o som limpo, claro.
} 
Este é o cenário onde o Festejo acontece. Ela bateu na porta dizendo: “Abram esta porta! Minha Caixa não entra pela porta dos fundos!"

Há Caixeiras que relatam que sua confiança e sua memória se expandem ao tocar a Caixa, e que não conseguem improvisar ou se lembrar das sequências sem tocá-las. Esse fato adquire significados ampliados pela enunciação de Stuart Hall de que povos dispersados em situações diaspóricas "guardam e transmitem a estrutura profunda de sua vida cultural na música, usando o corpo como se fosse, e muitas vezes foi, o único capital que possuíam" (HALL, 2003, p. 324).

Uma compreensão formulada também por Maria Antonieta Antonacci, para quem a oralidade remete ao universo de pessoas socializadas por mediações da voz e do gesto onde:

Corpo e memória são indissociáveis (...) e suas tradições transmitidas em presença de corpos, materializam-se em gêneros não-verbais de narratividade inerentes à moldagem de corpos enquanto fontes vivas, que perenizam rumores de culturas latentes em dobras da dominante civilização ocidental cristã. (ANTONACCI, 2013, p. 153-154). 


\section{CAPÍTULO 2}

A pomba do Espírito Santo

Não é de ouro, é de prata

Quem festeja Esprito Santo

Não é branco, é mulato

(quadra do repertório das Caixeiras de Alcântara)

\section{1 - Os movimentos de população aos olhos desta Festa}

Uma questão particular proposta por Alan Lomax na Cantométrica, sua extensa pesquisa em busca de uma análise comparativa global de estilos musicais, é o questionamento do papel da História na formação daqueles com o quais se deparou na construção de seu trabalho.

Trago esta questão como suporte para incluir alguns dados dos movimentos de população para o Estado do Maranhão na busca de construção do contexto onde acontecem os festejos do Divino. Com este objetivo, localizo no mapa de microrregiões (Figura 2), aquelas onde se observa incidência de Festejos.

A definição das microrregiões do Estado com maior incidência de festejos foi possível com o apoio da pesquisa anterior para o mestrado em História e com a escolha das locações para a produção do documentário Umas Mulheres que Dão no Couro: As Caixeiras do Divino no Maranhão, que nos levou a gravar em 16 municípios localizados nas microrregiões referidas a seguir.

A localização destes festejos foi possível graças à assessoria do experiente pesquisador maranhense Jandir Gonçalves ${ }^{15}$.

15 Jandir Gonçalves é Diretor do Museu Casa de Nhozinho, equipamento da Secretaria de Cultura do Estado do Maranhão. Membro da Comissão Maranhense de Folclore é respeitado pesquisador das manifestações culturais do estado. 


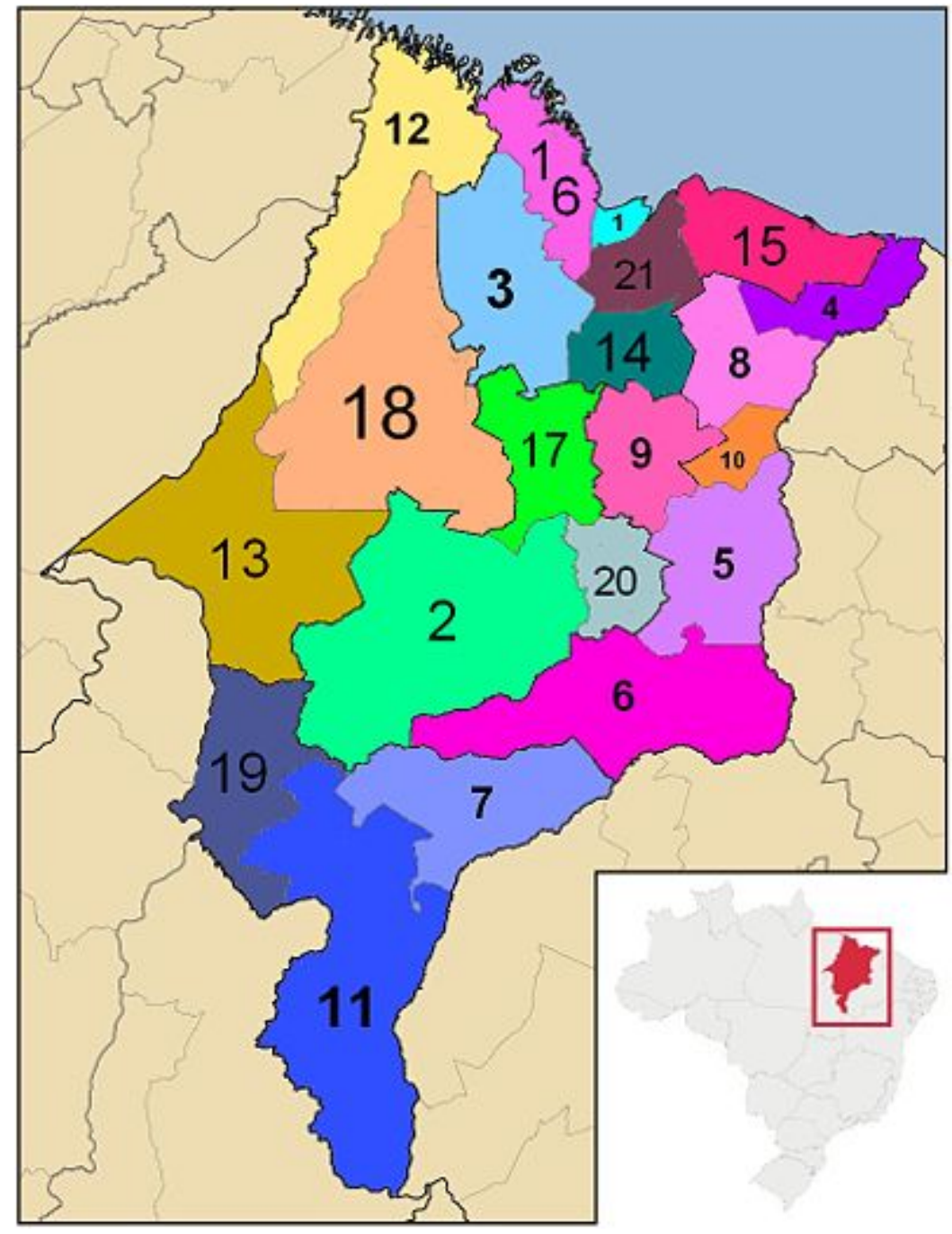

Figura 2 - Mapa das Microrregiões do Estado do Maranhão

(1)Ilha de São Luís, (14) Itapecuru-Mirim, (3) Baixada Maranhense, (16) Litoral Ocidental Maranhense, (21) Rosário, (15) Lençóis Maranhenses.

Cabe dizer aqui que a devoção ao Divino, no Maranhão, se amplia em duas grandes formas: o Divino celebrado nos Festejos conduzidos pelas Caixeiras e o Divino como Consolador na morte onde os cultos são conduzidos por homens; os Foliões da Divindade. Estes atuam em um campo de significados relacionado à morte e aos mortos. Tocam e cantam em duplas ou grupos que incluem alguém que carrega a Divindade; um Pombo branco que ostenta colares com miçangas dentro de um pequeno altar carregado por uma pessoa do grupo. O grupo é liderado pela bandeira do Divino que, ali, tem no centro um círculo azul marinho ou preto com três estrelas brancas e o pombo branco ao centro.

Os Foliões visitam covas em cemitérios cantando um repertório para consolar os mortos em sua solidão, levar lembranças de familiares. Acompanham enterros, pagam 
promessas que os mortos não conseguiram realizar, viajam pedindo joias para a realização de festejos que têm roteiro específico. Essas práticas rituais são encontradas preferencialmente nas Microrregiões de Baixo Parnaíba Maranhense, Caxias, Coelho Neto, Chapadinha, Alto Mearim e Grajaú. Estão citadas aqui como informação sobre a diversidade dos festejos para o Divino Espírito Santo mas não serão objeto de reflexão no corpo deste trabalho.

Acrescento aqui algumas informações de contexto sobre o longo processo de ocupação e consolidação do território ao norte dos domínios portugueses na América, organizado pela criação do Estado do Maranhão e Grão-Pará. ${ }^{16}$ A dinâmica política que envolveu o governo deste estado, provocou um processo de alternância de sua capital entre S. Luís e Belém consolidando esse território que coexistiu com o Estado do Brasil como se pode observar pelo Mapa (Figura 3), à página 56. Ambos Estados tinham governos independentes e reportavamse diretamente à coroa portuguesa, em uma relação que perdurou até 1772, quando o Estado do Maranhão e Grão-Pará foi anexado ao Estado do Brasil pelo decreto régio de 22 de agosto.

A consolidação do Estado do Maranhão e Grão-Pará exigiu sua ocupação dada a sua importância geopolítica e esta se deu em meio a ameaças constantes, ainda no século XVII, como o descreve Luciana de Fatima Oliveira. A autora relata que ataques de corsários e piratas movidos pelas notícias da existência de minas de ouro eram comuns. Outra ameaça era a natureza do trecho costeiro da Terra de Santa Cruz e sua "natureza agressiva". (OLIVEIRA, 2011, pp. 5-8).

Oliveira inclui na descrição das dificuldades de navegação pela região, a carta do padre Antônio Vieira quando, atravessando a Serra de Ibiapaba do Maranhão ao Ceará por mar, passou por tantas dificuldades entre os ventos e as "correntes contrárias", que depois de muitas tentativas de navegação, resolveu partir por terra. (OLIVEIRA, 2011, p.7).

Em carta ao seu superior, Gosvínio Nickel, Vieira relata as dificuldades de comunicação tanto por mar, quanto por terra, entre o Estado do Maranhão e Grão Pará e o Estado do Brasil:

Nem se pode dizer que os que não tiverem seus estudos acabados os irão acabar ao Brasil, ou a outra parte. Porque quanto ao Brasil ainda que de lá se vem ao Maranhão facilmente, a viagem do Maranhão ao Brasil é hoje quase impossível. Exemplo seja que, de oito embarcações que partiram para lá, depois que estamos nesta Missão, só uma chegou a Pernambuco; todas as

\footnotetext{
${ }^{16}$ Cf. Mario Meirelles; A História do Maranhão e também o trabalho de Luciana de Fatima Oliveira sobre o Grão-Pará e Maranhão.
} 
mais arribaram depois de muitos meses de grandes trabalhos e despesas... Por terra ainda é mais dificultoso o caminho, porque do Maranhão à Baía, onde estão os estudos são quinhentas léguas, e as trezentas delas totalmente desertas... Este caminho do Maranhão ao Brasil só o fez um Governador de Pernambuco com todo o poder do seu cargo, e com grandes despesas da fazenda. E só em algum caso semelhante se poderia oferecer ocasião em que algum nosso, e esse mui robusto, pudesse empreender esta jornada, a qual não havia de acabar em seis meses. Assim que ir estudar ao Brasil, não é cousa praticável. Ir a Portugal fôra menos dificultoso, pela comodidade da viagem, e embarcações, mas nem o consentem as despesas, nem os riscos, que são ordinários, caindo muitos navios que vão do Maranhão em mãos de corsários, e alguns deles nas dos Turcos (LEITE 1940, apud OLIVEIRA 2011, pp. 5-6).

Essas relatadas dificuldades de acesso e circulação por mar e terra entre o Estado do Maranhão e Grão-Pará e o Estado do Brasil, oferecem elementos para pensar as relações construídas entre aquele Estado, Áfricas e Europa. Do mesmo modo, elementos para reflexão sobre as zonas de contato, nas quais as culturas têm seu processo de formação, de construção, onde as identidades concebidas como estáveis, naufragam.

Para Stuart Hall, as culturas sempre se recusaram a ser perfeitamente encurraladas dentro das fronteiras nacionais. Elas transgridem os limites políticos (HALL 2003, pp 35-36) e não se apegam a modelos fechados, unitários e homogêneos de pertencimento cultural. Nesta construção, abarcam processos mais amplos, o jogo da semelhança e da diferença que transforma a cultura no mundo inteiro, afrouxando os laços entre a cultura e o lugar (HALL 2003, p. 47).

Neste processo as cultura são manifestamente o resultado do maior entrelaçamento e fusão, na fornalha da sociedade colonial, de diferentes elementos culturais africanos, asiáticos e europeus (HALL 2003. P. 31) e para a experiência brasileira, destaca-se a presença indígena. África na sua concepção é o significante, a metáfora para aquela dimensão de nossa sociedade e História que foi maciçamente suprimida, sistematicamente desonrada e incessantemente negada.

Relaciona-se à realidade desta construção, as informações trazidas pelos documentos do Catálogo de documentos manuscritos avulsos referentes à capitania do Maranhão, existentes no Arquivo Histórico Ultramarino. Dele constam petições do então governador do Maranhão, Albuquerque Coelho de Carvalho, ao Rei Afonso VI, "para que se enviem àquele estado casais das ilhas dos Açores e Madeira e alguns presos". 


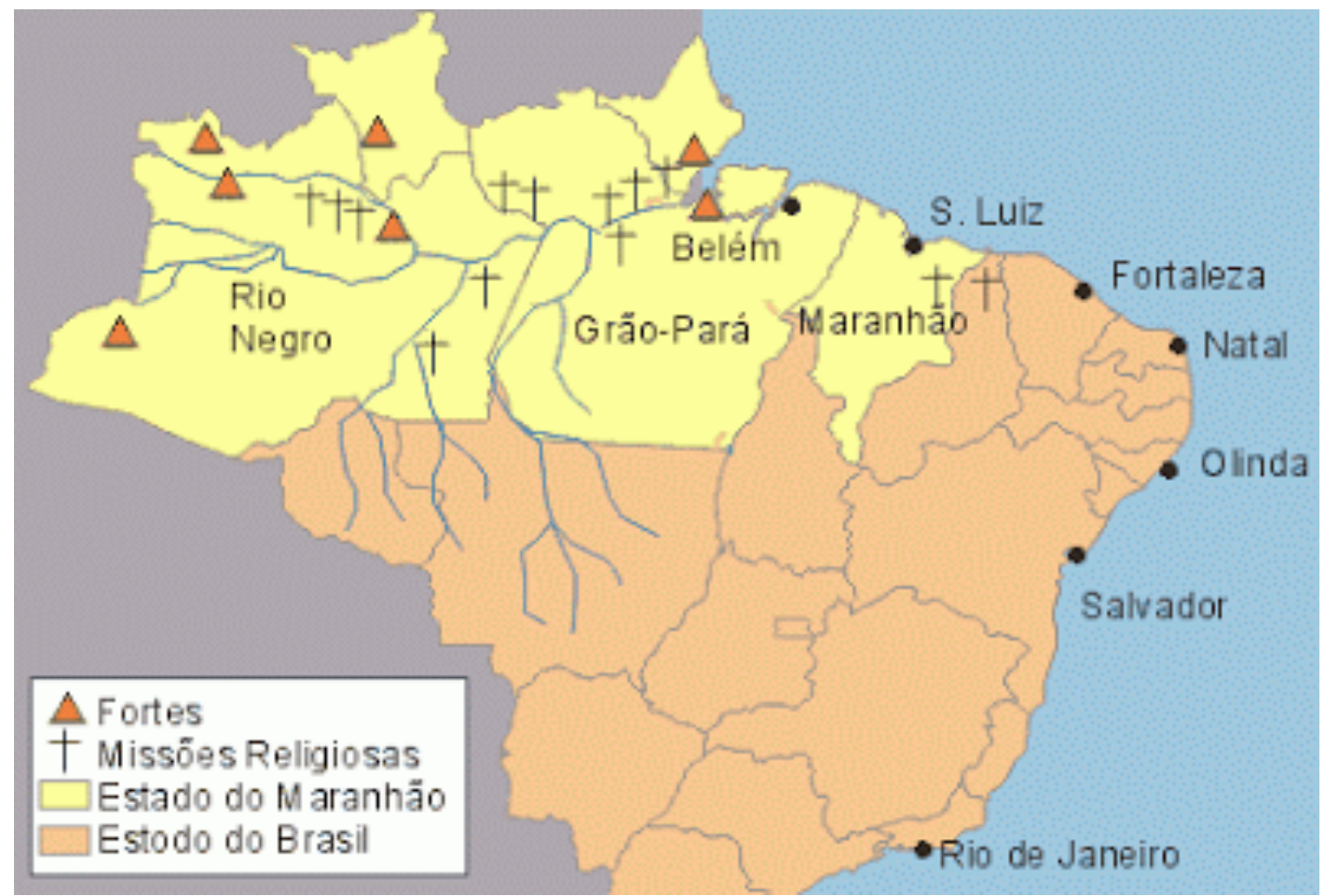

Figura 3 - Mapa: Estados do Brasil e do Maranhão e Grão-Pará

Desse modo, muitos açorianos foram levados para o Maranhão desde 1618, um movimento de população que se seguiu por vários anos do século XVII. Chegaram em grupos de duzentos casais, cada um deles, em média, com o objetivo de "formar a população do lugar”, nos ensina Carlos de Lima (1981).

Maria Celeste Gomes da Silva em trabalho de 2010, pesquisa a vida e a economia do Maranhão que tiveram sua existência entretecida aos povos indígenas que ali viviam. Até meados do século XVIII, os indígenas constituíam a principal força de trabalho na condição de escravizados, livres ou aldeados. Subjugados, exerceram papel fundamental na consolidação da expansão portuguesa na Amazônia colonial. Trabalhavam no transporte por canoas, como guia nas jornadas e expedições, nas lavouras de tabaco, cana-de-açúcar, na extração do cravo e da baunilha, entre outras ocupações, e muitos povos indígenas foram destruídos, dizimados. Outros povos se mantém vivos em grande parte do centro do estado.

Analisando mapas de escravatura do Arquivo Histórico Ultramarino, Gomes da Silva oferece também dados sobre a presença de africanos escravizados no Maranhão e trago alguns desses dados para uma breve compreensão do contexto histórico do movimento de população na região. 
De 1775 até 1799 um total de 32.343 escravizados no Maranhão assim distribuídos: De 1775 até 1784, por intermédio da CGGPM - Companhia Geral do Grão Pará e Maranhão e de 1785 até 1799 , sob forma de contrato e levados por particulares.

Gomes da Silva tem como foco de sua análise o lugar de origem desses africanos escravizados e destaca a existência de 29.188 cativos, dos quais, aproximadamente $73 \%$ (21.168) provinham de portos africanos. Cabo Verde (19); Costa da Malagueta (40); Costa da Mina (184); Moçambique (371); Benguela (425); Guiné (1.972); Angola (3.237); Cacheu (6.099); Bissau (8.821).

Os restantes 27\% (8.020) eram provenientes de portos brasileiros. Eram peças que não haviam sido vendidas em portos onde desembarcaram originalmente. (GOMES DA SILVA, 2010).

Esses vigorosos movimentos de população existentes na região, além das dificuldades de trânsito para fora dela, evidenciam processos de trocas materiais e simbólicas, recriações, apropriações, ressignificações locais, construções culturais e musicais em diálogo dinâmico com o tempo e o espaço.

Paul Gilroy conceitua diáspora africana como movimentos de população, mas também, e principalmente, disputa, frequentemente muda, sobre os códigos reguladores da maneira pela qual a história das culturas negras são escritas. Aí se incluem a maneira como as formas geográficas e culturais de vida na memória e corpos de africanos(as) contataram e contatam outros contextos pelas formas como são incorporadas, como modificam e são modificados por eles (GILROY, 2001).

Gilroy acrescenta que esses movimentos de população configuram-se como "empreendimento político, histórico e filosófico" e não se limitaram ao acontecimento imediato do tráfico de escravizados. São diáspora também as movimentações sucessivas de indivíduos durante o século XIX e XX, neste último sobretudo nas décadas de 50 e 60 com o ingresso de africanos em universidades dos Estados Unidos, da Inglaterra e do Brasil (GILROY, 2001).

Refere-se também às misturas decorrentes desse movimento, deslocando a importância das origens e continuidades de traços culturais para a compreensão dos processos de transformação criadora de novas formas culturais. E esta é a motivação desta pesquisa sobre a 
forma particular de cultuar o Divino que foi criada no Maranhão bem como a existência das Caixeiras.

O momento da formação histórica para qualquer campo de significados é crítico, alerta Stuart Hall. Um determinado período histórico, deixa traços de sua vinculações bem depois do desaparecimento das relações sociais às quais se referiam. (Hall, 2006, p 182).

Esta reflexão apoia a compreensão da referencia frequente à escravidão pelas mulheres Caixeiras em Alcântara. Ana Benedita Ferreira, a Anica, em entrevista aos 74 anos em 2005: "Quando me entendi, não achei mais escravatura..."

D. Margarida Maria de Araújo antiga Caixeira-Mór em Alcântara em entrevista de 2005 apresentada na íntegra à página 62, relata o universo das antigas Caixeiras e a criação dos repertórios para o Divino: “Aquilo é daquelas pretadas velhas, antigas, escravas! Isso é do tempo da escravatura!

D. Raimunda Soares, Raimunda Boró em depoimento no ano de 2000 aos 92 anos, identifica como o ganho o que recebia por seu trabalho como Caixeira Mór do Festejo da cidade.

Tempo de festa festeiro dava. Dava desde o calçado. Roupa, calçado, comida, tudo tinha! Tudo á vontade! Inda hoje é a mesma coisa! Caixeiras ganham. Ganham comida, dormem na casa de festeiro. (...)quando termina a festa, $o$ ganho!... Graças a Deus!

O ganho é uma expressão ao sistema de exploração no qual as mulheres escravizadas saíam de casa para vender, por exemplo, quitutes que elas mesmas ou suas proprietárias faziam, e recebiam uma parte do valor dessas vendas.

A grande maioria das Caixeiras no Festejo do Divino de Alcântara moravam ou se originavam de comunidades rurais quilombolas da região. Alcântara é a sede de um município com um grande número delas, "mais de centena e meia de povoados camponeses que reivindicam a condição de quilombolas" (SOUSA FILHO; PAULA ANDRADE, 2012 p 76).

Maristela de Paula Andrade e Benedito Sousa Filho desenvolvem estudos das comunidades rurais e sua relação com a terra nesta região e questionam a historiografia regional que enfatiza a decadência de Alcântara do ponto de vista econômico. Esta decadência costuma ser ilustrada pela existência de um grande número de palacetes abandonados pelos 
antigos habitantes aristocratas, pela paralisia dos negócios na cidade do ponto de vista da pragmática capitalista.

Paula Andrade e Sousa Filho evidenciam a conotação positiva desse quadro sócio-histórico que possibilitou e oferece explicação do processo de controle territorial por outros grupos sociais que adquiriram autonomia e constituíram regimes culturais próprios: “indígenas desaldeados e escravos africanos passaram a viver livres da subordinação, construindo regras próprias para se assenhorear das terras e demais recursos após a retirada dos donos de engenho". (SOUSA FILHO; PAULA ANDRADE, 2012, p 76).

Desse modo, estas comunidades viveram por mais de um século praticamente à margem da interferência oficial, desde o início do século XIX à década de 1980 do século XX. Naquele momento se iniciou "o processo de implantação de um centro de lançamento de artefatos espaciais pelos militares, originando conflitos que se estendem aos dias de hoje" (PAULA ANDRADE, SOUZA FILHO apud PAULA ANDRADE, SOUZA FILHO, 2012).

Destacam que, nestas comunidades as festas de santo, para além da riqueza de detalhes de suas cerimonias, podem ser pensadas como celebrações da autonomia conquistada pelos ancestrais neste processo.

A “música forjada em dispersões irreversíveis na diáspora”, tem nos rituais, um espaço performático possível. Pela retórica do corpo, pela apropriação e rearticulação seletiva de ideologias, grupos sociais, então à margem, construíram formas de usar o espaço social alheio.

Denominando "resultados culturais híbridos" àqueles produzidos na "fornalha do sistema colonial”, Stuart Hall é veemente na argumentação de que estes não se constituem simulacros das culturas colonizadoras. Grupos subordinados ou marginais selecionam e inventam a partir dos materiais a eles transmitidos, num processo de zona de contato. E por zona de contato entende-se a co-presença espacial e temporal dos sujeitos anteriormente isolados por disjunturas geográficas e históricas “cujas trajetórias agora se cruzam”.

O Etnomusicólogo Robin Moore observa o dinamismo e movimento do uso do conceito de diáspora e sua mudança no tempo a partir do Caribe onde concentra sua pesquisa. Ao caracterizar a realidade com a qual se depara, identifica tradições que ligam o Caribe à África musical, linguística ou ideologicamente. Este fato distingue setores da população afro- 
caribenha em um processo que cria afinidades com uma noção mais ampla de patrimônio diaspórico compartilhado.

Acrescenta que os caribenhos nem sempre se identificam como grupo unificado ou identificam a África como sua casa, destacando ainda a compreensão do Caribe como fundamentalmente mestiço, crioulizado, híbrido. Observa ainda que, em muitos casos, as influências europeias indiscutivelmente predominam sobre as influências africanas dentro do repertório musical ali construído.

Moore refere-se a Rogers Brubaker e Paul Gilroy, com quem compartilha a noção de que a consciência diaspórica é melhor compreendida se a identificarmos como uma posição ideológica ou reivindicativa de algum grupo, útil por algum período. Destaca e critica a ênfase de Paul Gilroy sobre a experiência da opressão racial como formadora das culturas da diáspora africana nas Américas e do Atlântico Negro. (MOORE, 2012).

Moore destaca que os conceitos de diáspora têm recebido diferentes significados no tempo. Diáspora compreendida como um processo de deslocamento ou movimento traumático, como identificação com uma pátria distante, com processos de preservação de uma identidade distinta daquela circundante. E ele acrescenta outro ponto; uma tendência a identificar--se com outros grupos diaspóricos de semelhantes origens culturais ou de outra natureza.

Moore dirige sua pesquisa para os estilos musicais caribenhos em diálogo com o mercado local e internacional e identifica que "o modelo musical que parece caber facilmente dentro dos paradigmas diaspóricos inclui a percussão tradicional e a canção frequentemente associadas ao culto religioso e são realizadas em línguas africanas fragmentadas com acompanhamentos de instrumentos e ritmos com antecedentes diretos das Áfricas. (MOORE, 2012).

As observações de Moore para o Caribe, podem ser identificadas no Maranhão pelas doutrinas, canções da música ritual propiciatória dos cultos religiosos no Tambor de Mina e Candomblé. Estes têm importante função, a de definir um espaço simbólico e a sensação de um patrimônio comum e que coloca a matriz africana no centro do culto coletivo.

Mas o universo das Caixeiras traz em sua performance, a Caixa um instrumento comumente associado aos tambores militares europeus. Traz em si a discussão sobre as misturas culturais e religiosas em universos que têm a matriz africana no centro dos cultos 
coletivos. Esta discussão é desenvolvida neste trabalho no Capítulo 3 pelo caminho da identificação das estruturas musicais ali presentes.

Compreender as Caixeiras do Divino e a construção de sua música como sujeitos históricos, buscando sua relação com a experiência diaspórica, exige o diálogo com a cultura popular como campo de investigação. E Stuart Hall ensina que:

os termos "classe" e "popular" estão profundamente relacionados entre si, mas não são intercambiáveis, porque não há culturas inteiramente isoladas e paradigmaticamente fixadas em uma relação de determinismo histórico a classes inteiras, embora existam formações culturais de classe bem distintas e variáveis (HALL, 2006 p 244).

O termo popular indica este relacionamento, um tanto deslocado, na compreensão de Hall entre a cultura, as classes, e as forças que constituem as classes populares, cultura dos oprimidos, das classes excluídas. E em oposição, há o lado de poder cultural de decidir o que pertence ou não às classes populares. A cultura do bloco de poder.

Com estes dados de realidade observamos uma entrevista com D. Margarida Moura de Araújo, Caixeira na Festa em Alcântara para o documentário e que se destaca em sua capacidade de conectar informações. D. Margarida falava sobre o cantar da Alvorada, um momento ritual de grande gravidade, e as cantigas associadas a ele:

Repara que quando a gente canta Alvorada dentro daquele salão, aquilo faz um silêncio! Aquilo é daquelas pretadas velhas, antigas, escravas! Isso é do tempo da escravatura! E nesse tempo, era elas era quem mandava nessa festa. Era elas e os home! Aqueles preto escravo, tudo era quem sabia tocar, era quem tirava esses cântico, esses toque, eles era quem fazia. Por uma dessa, é que hoje em $\mathrm{S}$. Luís não tem um toque igual o nosso e nem o nosso é igual ao deles! Esses cântico nosso aqui até já mudou mais...

Porque quando eu me entendi esses cântico aqui dessa festa do Espírito Santo era uma coisa muito linda minha filha! Agora eu não sei o que teve, que elas foram perdendo. Aquelas mulheres Caixeiras antiga, foram morrendo e foi ficando aquelas, aquelas... Umas caprichavam; Vamos fazer tal Toque assim, assim, assim? 'mbora... elas faziam. Outras já dizia: Que nada! Vamos largar esse Toque, esse toque é triste, faz lembrar de fulana, cicrana, bertrana... Olha, eu conheci bem umas 20 Caixeiras velhas, aquelas pretonas velhas, antigas tocando Caixa! As roupas eram bem por aqui assim...(aponta para a metade da perna, indicando que eram roupas compridas), aquelas saionas (amplia as mãos ao redor dos quadris para mostrar amplidão)! Isto delas aqui, (aponta o próprio pescoço) era cheio daquelas vorta, aqueles colarzão! As blusa era só aqueles rendão!

A descrição feita por D. Margarida relata mulheres cujo vestuário incluía golas em rendão, muitos colares, saias amplas e compridas, evidenciando riquezas. Esta descrição alinha--a à linhagem dessas mulheres "valoriza seu parentesco, contextualiza sua história, 
reescreve seus ídolos" para usar palavras de Paul Gilroy. A postura de seu corpo se modifica enquanto fala conferindo ainda mais dignidade à sua presença.

Busquei imagens que pudessem ilustrar uma mulher com a aparência descrita por D. Margarida com colares e adereços, rendas e amplas saias. A Figura 4, uma aquarela que identifica a Preta Mina e Crioula do Maranhão (cópia do natural em 1880).

A denominação Mina traduz uma compreensão de descendência presente no Maranhão. Compreensão derivada do fato de que uma grande quantidade de africanos e africanas escravizados e levados para lá e embarcados no porto de São Jorge da Mina e ou levados de seus territórios até os portos da Costa da Mina.

Um artigo de José Ferreira no site do Centro de História d'Aquém e d'Além Mar, informa da fixação dos portugueses em São Jorge da Mina como produto da exploração da costa ocidental africana, ao longo de todo o século XV. Intensificada a partir de 1498 com a concessão ao mercador Fernão Gomes a exploração de cem léguas de costa africana, por ano, com navios armados por ele. Este fato levou ao primeiro resgate de ouro no golfo da Guiné em 1471, na região do Gana. Esta descoberta ocorreu na região entre o cabo das Palmeiras e o rio Volta, área que seria, consequentemente, denominada Costa da Mina. 


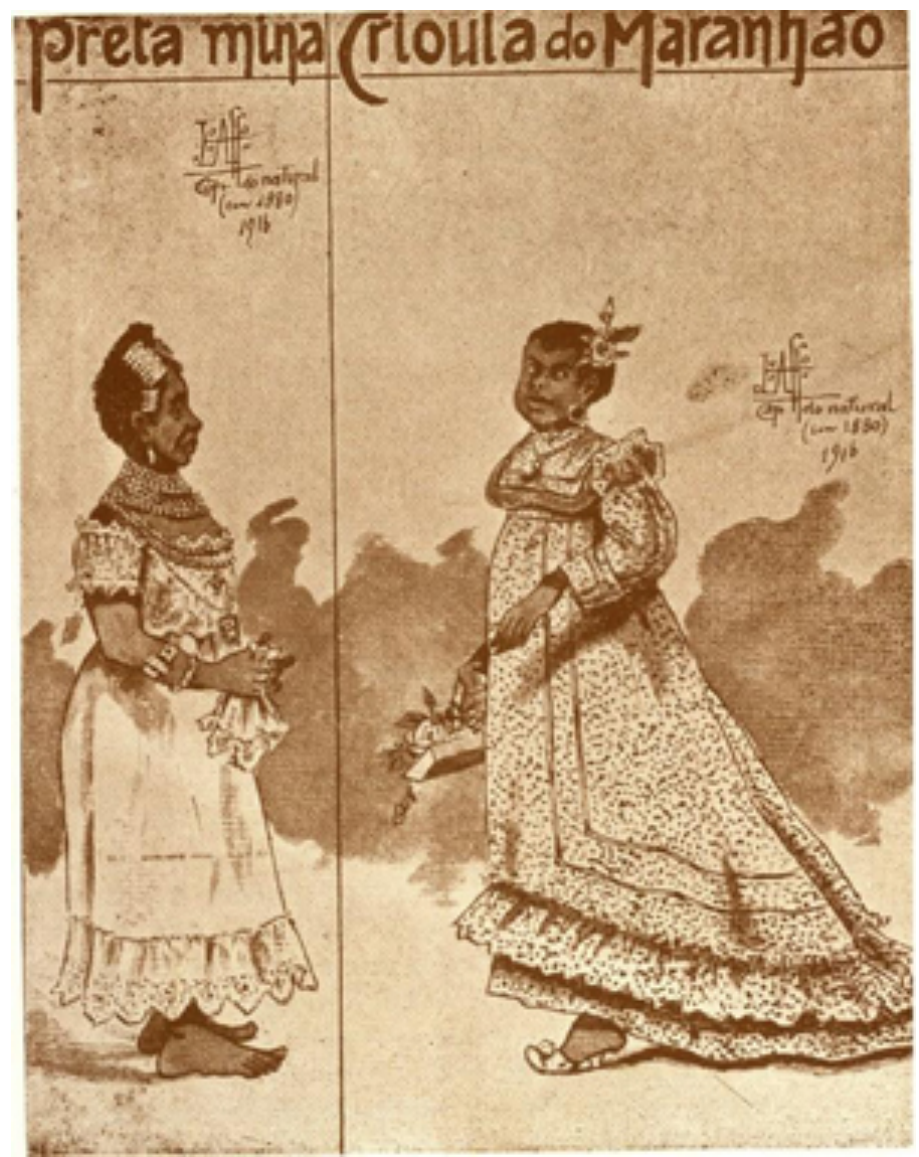

Figura 4 - Aquarela: Preta Mina e Crioula do Maranhão

Esta aquarela de João Affonso do Nascimento, 1915. COR-BPAV, Belém. Está disponível no site: Histórica - Revista Eletrônica do Arquivo do Estado de São Paulo ${ }^{17}$. Nela se observam desenhos representando duas mulheres. A Preta mina e a Crioula do Maranhão.

Estas imagens evidenciam o olhar desdenhoso do artista ao escolher o traço caricatural para representar essas mulheres e o texto que a acompanha agrega informações a esta forma de construção do significado. Aqui um trecho:

Olhando para o passado, sob a aura republicana, as histórias ganhavam ainda mais o sentido pitoresco de elemento primitivo formador de nossa, ainda tênue, nacionalidade, aqui enfatizada pela diferença das raças e costumes contribuintes do amálgama. Apenas desse modo a escravidão poderia ser citada na história da arte republicana, nos exageros e no mau uso das joias pelas negras: "enquanto a gente de poucos recursos se contentava em forrar com oleado" todos aqueles bentinhos, "para preservar do contato do corpo, ela queria que fossem metidos em duas chapas de ouro". Mas, apesar de tudo, não conseguia apagar sua posição social: E com toda esta ostentação de estofos finos, rendas caras e adornos de ouro, a preta mina ia descalça.

\footnotetext{
${ }^{17}$ http://www.historica.arquivoestado.sp.gov.br/materias/anteriores/edicao53\%5Cmateria01/
} 
E prossegue:

Histórias não faltavam na recordação das pessoas. Era difícil encontrar em São Luís, entre os mais velhos, quem não lembrasse da "abastada capitalista", a africana forra Catharina Mina, negociante de farinha, com armazém à rua do Trapiche, que teve o capricho de casar com cafuz, para quem arranjou uma patente de alferes da Guarda Nacional, cujo caso foi motivo de lembrança numas pequenas historietas e comédias de Arthur e Aluísio Azevedo, ainda em seus tempos de Maranhão, encenadas por eles mesmos, incluindo aí o próprio João Affonso, no teatrinho do antigo Largo do Carmo, em São Luís.

D. Margarida Maria de Araújo, a então Caixeira Mór do festejo de Alcântara em entrevista no documentário já referido, descreve positiva e vivamente semelhantes adereços em ouro, e a renda presente nas golas das blusas, das roupas das antigas Caixeiras que ela conheceu representando-as como mulheres que tinham posses e bens acumulados.

As sociedades escravistas eram atingidas em seus pilares com a existência dessas mulheres forras ou ainda escravizadas, capazes de fazer negócios tanto com seu tabuleiro nas ruas, quanto negociando em grandes empreendimentos, inclusive no tráfico de escravizados. Capazes de articulação política, alçavam-se de uma condição de servidão para a de proprietárias, donas de si e de seus negócios, usando os seus recursos como se lhes aprouvesse.

O texto citado acima demonstra que o teatro burguês com sua capacidade de fazer rir com o deboche, foi um porta—voz da indignação e agressão da sociedade escravista dirigidas a elas e seus modos de viver.

\section{2 - Diálogos entre o repertório musical e os roteiros rituais dos Festejos}

Uma origem portuguesa é atribuída a essa Festa, em uma versão hegemônica em meio a muitas outras. Expulsa do continente, essa Festa instala-se no Arquipélago dos Açores e de lá se difunde, construindo uma geografia atlântica conforme dados de João Leal. (Leal 1996, 2009a, 2009b).

A memória coletiva apoia a leitura das informações de Dona Celeste Santos, Caixeira e organizadora da Festa do Divino na Casa das Minas até sua morte em 2010. Aqui trago sua fala sobre a extensão do repertório da Festa no Maranhão: 
...tem milhões que a gente sabe, que a gente aprende com a outra, mas os principais são oito: Alvorada, que é o principal, tem que ter. Alvorada se faz três vezes no dia da Festa. É de manhã cedo, entre 5 e 5:30, no meio-dia e 6 horas da tarde. Quando termina, vamos cantar pra Senhora Santana. Depois de Senhora Santana a gente canta outros.

Tem o cântico da Abertura da Tribuna, que a gente canta primeiro quando vai abrir a Festa. São Dois Espírito Santo. O Dobrado e o Corrido. São dois, com mais outros dois, são quatro. Aí tem o Toque da missa que a gente faz em procissão. Já tem mais um. Cinco. Depois tem o toque de suspender o Mastro. Seis, né? Aí tem o Toque que passa a Tribuna, o Toque que faz o trespasse das posses. E a dança das Caixeiras. Tem uma porção que a gente toca, mas esses são os necessários.

Toques e seus momentos na Festa, na versão de D. Alzira:

A festa é feita de visitas para o Imperador, Imperatriz, Mordomo Régio, tem uns que deixa completar tudo só dentro da casa, e outros nós temos que sair.

Porque tem o Toque dobrado que é o de Divino Esprito Santo, é Três Pancada; e tem o Toque Corrido, e tem o Toque Compassado conforme seja a salva que a gente cantar. Tem que tocar tudo compassado, tudo ali lento, isto é que é!

Por exemplo, o ritmo da alvorada se chama Alvorada. Pra abertura da festa antes de ir buscar a coroa é a salva. Nós cantamos toda a salva, mas na hora de sair, é como você viu, se cantou outra, de saída. Quando chegar lá, tem que tocar Esprito Santo Dobrado. É um Toque que tem, é dobrado e se usa pra poder receber a Santa Crôa. Agora, recebeu, já é outro, e vem com o Esprito Santo Dobrado até chegar aqui. Aí chega aqui e muda pra qual quiser. Agora o da obrigação é esse. O Divino Esprito Santo Dobrado.

Alvorada é 6 horas (18hs), meio-dia e de madrugada, as quatro horas da madrugada. Alvorada vem se tocar aqui. Agora pra se fechar a tribuna, pra botar no artá os Império, e o Divino Esprito Santo, já é outro toque, pra fechar a Tribuna já é outro toque. E já outra coisa, outro toque. Eu não sei se existe nome. Porque ás vezes tem e eles não falam, né?

Algumas sequências de versos cantados nos rituais para o Divino são os Benditos ${ }^{18}$ ou fragmentos de Benditos. Estes são cantos cristãos que contam e cantam histórias, relatam passagens bíblicas, vidas dos santos.

O historiador Moisés Espírito Santo pesquisou as origens orientais das festas populares portuguesas, e atribui a origem desta festa aos rituais do antigo judaísmo popular. Ele afirma que os benditos são cantos cristãos que teriam sido inventados a partir do Qaddish judaico. Teriam sido ensinados em um sonho ao profeta Daniel, que desse modo entendeu que tinha o apoio de Yaveh para a questão da decifração do sonho de Nabucodonosor. Esses

${ }^{18}$ Verbete: Benditos são cantos religiosos que acompanham as procissões e, outrora, as visitas do Santíssimo. Denomina o gênero e uso da palavra BENDITO. In; Cascudo, Câmara. Dicionário do Folclore Brasileiro MEC, Instituto Nacional do Livro, Rio de Janeiro, 1962. 
Benditos teriam sido cantados obsessivamente, na sua opinião, durante as festas judaicas de Pentecostes. Aqui apresento um desses Benditos. Canta e conta os martírios de Cristo. (Espírito Santo 1989, p. 133)

Eu sou mais alta do que Deus

Ai mais alta que Deus eu sou

Ai sou mais alta nos pecados

Ai porque Deus nunca pecou

Ai eu estava na morte estava

Ai olhando pra uma luz

Ai eu vejo Jesus chegando

Ai nos braços da santa cruz

Ai a cruz que o senhor carrega

Ai é de madeira pesada

Ai fosse de madeira verde

A carga faz se ajoelhar

Ai se ajoelha pecadores

Ai vai beijar a santa cruz

E aonde chorou Maria

Ai pelo nosso bom Jesus

Ai Maria que foste aquela

Ai que estava em oração

E aquela que reduziste

Ai maior culpa de Adão

E a maior culpa de Adão

Ai dores de nossa senhora 
Ai se noss'alma bem soubesse

Ai recordava toda hora

Os Benditos se incluem no repertório antigo da festa como versos de fundamento. Antigos e respeitados, são considerados como um dos saberes que têm se perdido em repertórios de muitas casas, e muitas Caixeiras não os conhecem completos. Estes acima transcritos, foram gravados em Alcântara, mas estão também no repertório de muitos Festejos, inclusive o da Casa Fanti Ashanti.

D. Jacy, Caixeira Régia da Casa das Minas, analisa as sequências de execução para manter o tema proposto por aquela que botou, propôs a cantiga:

Antigamente, a gente só cantava Bendito. Hoje não! Elas não prestam atenção! Bendito é o seguinte. Se aquela começa a cantar pra ventilador, então o banco todinho tem que cantar pra ventilador, até a última e aquela que começou, encerra. Mas elas não prestam atenção, e a gente começa cantando pra cadeira e outra lá na frente canta pra espelho! Se a da frente tiver cabeça, continua com o espelho e as outras seguem, se não, canta outras coisas e a gente diz que desmoronou o Bendito. Ficou sem sentido!

D. Alzira Reis Pires ensina:

Porque você canta mas tem que ter memória pra tirar um verso. Se eu tirar um verso de Divino Esprito Santo, você tem que responder com Divino Esprito Santo, se eu tirar um verso com uma flor, você tem que responder, com uma flor, você tem que tirar que chega naquela flor também. Assim se eu tiro:

Meu Divino Esprito Santo

A vossa capela cheira

Cheira a cravo, cheira a rosa,

cheira a flor da laranjeira

Aí você:

Meu Divino Esprito Santo

Quero pra vós me ajudar

Abaixo de Deus Nossa Senhora e

São José de Ribamar 
Vai sempre falar de Divino Esprito Santo, até terminar... Se puxar São José, aí é sempre com São José. Esta é que é a significância da festa. Muito boa por esta parte. Mas vai pela memória. Porque você canta, você toca, mas não sabe tirar um verso, então você tem que estudar! Quando eu tirar um verso aqui, sua cabeça já está pensando o que você vai responder também. Este verso quase igual e quando você não der conta, a gente ensina, responde no seu lugar, pra você pegar aquele pedacinho de verso. Esse é que é o negócio.

O processo de aprendizado de uma Caixeira nova acontece durante os Festejos, embora possa incluir estudos fora dali. Esse vasto repertório de versos é mantido e recriado continuamente. Respeitando a estrutura formal, o estilo e a dinâmica ritual com apoio da prosódia, a Caixeira associa seu repertório de versos às melodias e Toques disponíveis. Com sílabas extras, encurtando frases em compensações métricas, engendra um corpo poético e musical com espaço para crescer com o improviso e a criatividade individual, no coletivo.

Por essa aguçada percepção prosódica, as Caixeiras ampliam seu repertório, adaptando versos em quadras a distintas melodias e métricas predeterminadas. E o fazem sem debilitar os sentidos do poema, ou a ideia que ele busca expressar. Não se trata de intuição, mas de um aprendizado longamente construído pelo desenvolvimento da percepção e pela prática do aprendizado no contexto do Festejo, como nos ensinou D. Alzira.

Maria Rosa fala de seu processo criativo, que ela atribui à inspiração pelo Espírito Santo:

é que eu sou assim, tipo... repentista! Até cantiga eu tiro. Essa aqui:

Eu vou, eu vou levar minha bandeira...

A do Divino Espírito Santo

Ô a coroa verdadeira....

Fui eu que $\operatorname{tirei}^{19} \ldots$. Bonita né? Aquilo vem na minha cabeça...”

Os versos que as caixeiras consideram como de fundamento, são os antigos que se referem à construção dos significados e sacralidades no universo do Divino, aqueles transmitidos pelas mais velhas. São valorizados como um dos critérios que definem o grau e a profundidade do conhecimento das Caixeiras.

\footnotetext{
${ }^{19}$ Tirar cantiga é compor. Construir tema e melodia e ritmo e levar para a roda para que todas possam aprender, responder e botar seus versos naquela estrutura.
} 
O improviso tem o seu lugar para acontecer e costuma ser desvalorizado, quando usado para substituir os versos de fundamento. D. Mônica, irmã de Margarida e também Caixeira do Festejo de Alcântara, fala do processo: “A gente tira verso, mas já tem conhecido de antigamente, já tem versos antigo das Caixeiras antigas que tirava e já foram deixando pra gente, né?"

Considerando os espaços de criação, legitimando o ensinamento das Caixeiras que a antecederam, destaca a responsabilidade de seu papel na existência desse conhecimento. 


\section{CAPÍTULO 3}

Do que já sabemos, parece claro que o ritmo é uma maneira de transmitir uma descrição de experiência, de tal modo que a experiência é recriada na pessoa que a recebe não simplesmente como uma "abstração" ou emoção, mas como um efeito físico sobre o organismo - no sangue, na respiração, nos padrões físicos do cérebro... um meio de transmitir nossa experiência de modo tão poderoso que a experiência pode ser literalmente vivida por outros. ( $A$ Longa Revolução, Raymond Williams, 1961, p. 40)

\section{1 - A música para o Divino}

A música das Caixeiras constrói lugares de poder e respeitabilidade e, por isso, exige transversalidade metodológica para sua compreensão. Para o objetivo deste trabalho interage com a assertiva de Michel de Certeau sobre o trabalho alquímico da História; "produzir imagens da sociedade com pedaços de corpos", (CERTEAU 2002, p 409). Os trechos musicais apoiam a produção dessas imagens da sociedade.

Um artigo de Marianna Monteiro e Paulo Dias sobre música popular brasileira refere-se à música para o Divino e ensina que essa música apresenta características que remetem à Idade Média, tais como: a sucessão de peças em forma suíte; a polifonia modal; os ritmos predominantemente ternários; ou com subdivisão ternária (o perfectum da rítmica medieval); e em hemíola, alternância métrica de ternário simples e binário composto. (MONTEIRO e DIAS, 2010).

A complexidade construída pelas múltiplas camadas de significados da Festa do Divino no Brasil inclui diferentes sequências rituais e sua música. Quando se observa os Festejos em Goiás por exemplo, a instrumentação se diferencia incluindo instrumentos de cordas; violas, violões, às vezes rabecas ou violinos, pandeiro e uma caixa. O canto se estrutura pelo diálogo entre duas duplas de vozes masculinas cantando em intervalos de terça maior. As vezes apenas uma dupla canta nesta estrutura de diálogo - e os grupos são formados por homens. As mulheres respondem em coro quando das cantorias nas casas, mas não pertencem ao grupo e sua presença é interditada durante os giros da folia. Em decorrência disso muitas transformações têm acontecido, entre elas a inclusão de caravanas que 
acompanham as Folias. Essas caravanas têm, em Goiás, o nome de Mussucas, e são organizadas pelas mulheres ligadas aos Foliões: esposas, mães, filhas, irmãs que iniciaram esse processo para também participar dos giros, mas essa é outra história...

A música das Caixeiras se organiza por canto, solo e em grupo, e a percussão de um grupo de tambores graves. Estes são comumente chamados tambor-mãe em culturas africanas onde dialogam com os solos dos dançantes, quando há tambores com outros timbres.

E nessa Festa do Divino no Maranhão, tocados em uníssono, constroem também um único e poderoso som e, tocados por mulheres, são o tambor-mãe presentes nesses rituais. Percussão remete a ritmos e estes estão presentes no corpo e no cotidiano. Falar sobre ritmos nos relaciona à questão dos andamentos, à velocidade com que se caminha, se canta, ou se toca. Como expressão humana que se organiza no tempo, a música tem o tempo de sua execução ligado diretamente ao tempo disponibilizado para ouvi-la.

Os tambores das Caixeiras, tocados compassadamente e em uníssono, constroem um tempo comum, presente, calmo, estabelecendo conexão entre esse tempo e as sensações das pessoas que assistem e participam do festejo. O Toque dos tambores e o canto constroem e conduzem a ambiência para os rituais, ao proporcionar a calma disponibilidade e atenção daqueles que deles participam.

Os universos musicais de matriz africana dos Terreiros permanecem separados daquele da música para os cultos festivos para o Divino por diferentes estruturas que se distinguem do ponto de vista performático, cênico, sonoro e pelas formas de organização no tempo. Em seu artigo Som e Música: Questões de Uma Antropologia Sonora, Tiago de Oliveira Pinto apresenta critérios construídos pela pesquisa de Gerhard Kubik para a compreensão das "estruturas sonoras e de movimento dos processos musicais cognitivos e performáticos de culturas africanas" presentes na música brasileira. (OLIVEIRA PINTO 2001, pp 238-241).

Com o objetivo de distinguir, neste trabalho, a música para o Divino daquela tocada nos cultos religiosos afro-brasileiros dos Terreiros, me apropriei dessas distinções de Kubik, agrupando-as e acrescentando informações construídas pela pesquisa em campo que distingo com itálico, nos subitens que se seguem. 
3.1.1 - Estruturas sonoras e performáticas da música afro-brasileira tocada nos Terreiros, de acordo com critérios definidos por Gerhard Kubik .

1. Trata-se de uma música ligada à dança e à percussão, formando um conjunto expressivo.

2. Há uma pulsação contínua de valores de tempo mínimo, uma condução rítmica mantida pelas cabaças cobertas com tecidos de contas ou sementes, instrumentos que nos terreiros, no Maranhão, costumam ser tocados por mulheres.

3. A polirritmia é presente e o ritmo, entendido como o ciclo rítmico, é construído pelo diálogo de frases com acentuações não coincidentes, tocadas pelos tambores de diferentes timbres e funções.

4. Um instrumento de timbre agudo, geralmente de ferro, toca uma frase que se constitui no padrão rítmico básico e que funciona como "cerne estrutural” da música. Chamados Gâ ou Agogôs, são, no Maranhão, geralmente tocados por mulheres.

5. O pulso marcado com firmeza, e ao mesmo tempo a grande presença de toques fora do tempo da marcação resultam em fraseados rítmico/melódicos, proporcionados pelo diálogo de tambores de diferentes alturas e timbres.

6. O canto tem estrutura de diálogo entre o solo e as respostas do coro.

7. A notação é oral e os ritmos são memorizados em forma de fonemas.

Aos critérios eleitos por Kubik, acrescento outros dois evidenciados pelo trabalho em campo.

1. Os tocadores são homens iniciados na tradição, com a função especifica de tocar os tambores. Por ocasião de sua morte, há rituais específicos e relacionados à sua função na Casa.

2. Há interdições dos tambores rituais às mulheres. 


\subsection{2 - Estruturas sonoras e performáticas da música tocada pelas Caixeiras nos Cultos} Festivos para o Divino.

1. As mulheres tocam os tambores e cantam. Seu canto é inseparável de sua performance.

2. As Caixeiras dançam apenas em três momentos que integram a sequência ritual; A Dança das Caixeiras é feita diante do altar do Divino e do Império e diante do Mastro, finalizando partes dos rituais.

3. Não há outro instrumento além das Caixas.

4. As caixas são tocadas em uníssono. Não se identificam polirritmias

5. As variações são previsíveis e esperadas, têm lugar para acontecer e geralmente são executadas pelas Caixeiras mais experientes.

6. Os Toques são precisamente associados a melodias e momentos rituais no culto festivo do Divino Espírito Santo.

7. Não há iniciação ritual das Caixeiras. Esta se dá com o processo de aprendizado, participação e performance na festa.

8. Há uma estrutura constituída de dois cargos; Caixeira Régia e Caixeira Mór. Inclui-se, em destaque, reiterada igualdade. Todas podem propor e improvisar cantigas e versos.

9. Os andamentos costumam ser lentos, na linguagem delas, compassados.

10. Os Toques têm caráter de circularidade dados pela presença de ritmos ternários ou binários compostos.

11. As acentuações dos pulsos básicos, no tambor, coincidem com as sílabas tônicas das palavras no poema.

12. Os cantos possuem várias formas de diálogo entre uma voz solo e o coro.

13. Quando da morte de uma Caixeira, não há rituais dedicados a ela que sejam relacionados ao seu papel de sacerdotisa nos cultos festivos ao Divino. Mas se ela é filha de Santo em Terreiros que realizam esses cultos, aí sim, há rituais relacionados às funções que ela desempenhava ali. 
As distinções acima relatadas apoiam a compreensão das articulações que têm lugar nos Festejos para o Divino realizados pelas comunidades dos Terreiros de Tambor de Mina, Umbanda e Candomblé em São Luís. O mesmo espaço físico e simbólico, cotidianamente destinado aos cultos afro-brasileiros, abre-se para os Festejos do Divino e o universo do Catolicismo Popular. Para esse diálogo, constrói-se um espaço-tempo, uma dimensão para receber os festejos do Divino. Uma dimensão que se abre e se fecha ritualmente: A Tribuna.

\section{2 - O cenário onde quase tudo acontece: A Tribuna}

O cenário montado para o ritual de Abertura da Tribuna costuma ser despojado. Um pequeno altar é montado sobre uma mesa. Velas, flores, uma bandeja e a Corôa do Divino, com a imagem do(a) pombo(a) acima. Um verso traz essa descrição do altar.

$$
\begin{aligned}
& \text { Em cima daquela mesa } \\
& \text { Tem uma salva redonda } \\
& \text { Em cima da Salva é Crôa } \\
& \text { Em cima da Crôa é Pomba }
\end{aligned}
$$

Embora fisicamente a Tribuna seja representada pelo espaço, no qual os Tronos e o Altar serão montados para a Festa, ela não se restringe a isso. Trata-se de uma dimensão sutil e D. Marcelina, Caixeira Régia do Ilê D’Ogum e Oxaguiam, em São José de Ribamar, traz importantes evidências no seu depoimento. Neste trecho de sua entrevista ela ensina sobre o processo de Fechamento da Tribuna.

... no fechamento eu canto pra subir tudinho. O Santo, os Santos com os anjos, tudo eu subo! Subo as flores, as cortinas, as toalha, as vela e os castiçá. E quando é pra abrir, chama de novo!

Porque não é a toalha que está no altar! É a toalha que o Divino fica! De qualquer maneira ele tá no céu mas tá na terra. Então tudo o que tem numa Tribuna, ele tá no céu, ele tá presente ali, e tudo tá formado pra ele com o poder do Pai Eterno, e dele mesmo, Espírito Santo! Então quando se canta pra subir o Pombo, não é este do altar... é o verdadeiro! A força do Divino, que vai levando a festa para o céu!

D. Marcelina alinha-se à compreensão da sacralidade envolvida neste ritual, no qual a própria divindade se aproxima pelo canal de comunicação já aberto pela música das Caixeiras e a convite do seu canto inspirado. Diferentes Caixeiras têm diferentes formas de realizar este ritual, e no caso de D. Marcelina, o repertório desse momento descreve o ambiente físico e 
simbólico construído pelo conjunto de crenças ligados às hierofanias ali presentes. A Tribuna tem seu espaço representado pelo Sacrário, o continente das sagradas insígnias, as chaves da festa, a luz e o fogo do Espírito Santo.

Na Casa Fanti Ashanti a preparação do festejo inclui a retirada das Caixas do lugar onde estiveram guardadas desde o ano anterior, para que recebam os cuidados necessários: limpeza, troca de couros, pintura se necessário, quando, então, esses tambores poderão ser tocados. Ressoarão desde o momento da Abertura até o fechamento ritual da Tribuna, quando as Caixas são novamente guardadas para o festejo do ano seguinte. A Casa Fanti Ashanti costuma reservar algumas Caixas, que não são usadas na festa, para emprestar a alguém que queira fazer um festejo ou Salva e não possua Caixas. Isto acontece porque as Caixas que foram tocadas durante a festa não podem ressoar fora do Tempo do Divino.

A Abertura da Tribuna na Casa Fanti Ashanti é ritual realizado pelo canto do Bendito de Hortelã, que descreve os martírios de Cristo em clima de grande densidade sonora, explicitando a sacralidade ali envolvida. Esse momento é conduzido pelo Toque Espírito Santo Dobrado, ou Três Pancada, que será observado de perto nesse capítulo.

Esse canto foi parcialmente apresentado a mim por Euclides Meneses, o Pai Euclides, líder da Casa. Por integrar os fundamentos sagrados da festa, o Bendito não deveria ser cantado fora do ritual. Mas Pai Euclides proporcionou a abertura do espaço para uma pesquisadora e cantou alguns trechos, destacando a forma de diálogo presente nessa cerimônia e desvelando sua sequência, de modo a dar a conhecer os sentidos atribuídos ao Bendito de Hortelã.

Reproduzo alguns versos para a Abertura da Tribuna com os comentários de Pai Euclides, que discrimino com o uso de itálico.

\author{
Sacrário está abrindo \\ A chave veio de Lisboa \\ O sacrário está se abrindo \\ Pra essa Divina Corôa
}

Deus vos salve Hortelã

Salvador da Boa fé

Viram se por cá passou

Bom Jesus de Nazaré? 
Ai outra pessoa responde:

Ele passou meia noite

Antes do galo cantar

Com o Cálix Bento na mão

A hóstia foi consagrar

Aí quando chega lá pelo meio, prá entrar na vida de Jesus Cristo...

Ai que missa tão bonita,

Nesta noite de natal

Se rasgou o véu do tempo

Apareceu o tribunal

Segue falando dos martírios de Cristo, Bom Jesus dos Navegantes, Bom Jesus da Coluna, Bom Jesus da Cana Verde, chega na rua da amargura, até quando chega o final, que diz assim:

Nesta rua da amargura

Poças de sangue deixou,

Foi o sangue de Jesus

Quando Pilatos matou

Outra pessoa responde:

Nesta rua da amargura

Poças de sangue correu

Quando o sol resplandeceu

O filho do Senhor morreu.

A música segue e cada verso cantado descreve um aumento lento e gradativo de abertura do sacrário simbólico, abrindo espaço e tornando visível a luz de seu interior. As Caixeiras seguem cantando a história até a completa abertura e iluminação do espaço-tempo, quando então a Tribuna está aberta. Realizam-se também, em outro ritual, oferendas para os Orixás, pedindo licença e proteção para a festa que irá se iniciar.

Este ritual de Abertura da Tribuna acontece pela aleluia na Casa Fanti Ashanti, embora o festejo seja realizado na primeira quinzena do mês de julho, meses depois. É realizado pelo canto do Bendito de Hortelã e o toque Divino Espírito Santo Dobrado, ou Três Pancada apresentado a seguir. 


\section{3 - Parêntesis para apresentar as partituras}

O canto e a percussão dos tambores, marcadores rítmicos privilegiados, estruturam a música das Caixeiras e, por isso, escolho os Toques nas Caixas, como eixo de reflexão com apoio das análises das partituras. Estas foram transcritas pela Etnomusicóloga e pesquisadora em educação musical Maria Cecília Jorquera, a partir de minhas informações e da escuta compartilhada do repertório escolhido.

As partituras que se referem aos Toques Alvorada, Alvoradinha e Espírito Santo Dobrado, foram reescritas a partir da transcrição feita anteriormente pelo Etnomusicólogo Paulo Dias. Os Toques Nossa Senhora Da Guia, Senhora Santana e a Alvorada que encerra o levantamento do Mastro em Alcântara foram escritos em primeira mão a partir das gravações no CD; As Caixeiras da Casa Fanti Ashanti cantam para o Divino, e No Bater da Minha Caixa estou Convidando as Foliôa, já citados anteriormente.

Cabem aqui algumas informações de percurso.

Essa é uma música cuja representação em partitura enfrenta dificuldades na fidelidade ao som. Os cantos nem sempre estão de acordo com o sistema temperado e o uso de recursos interpretativos, como os portamentos, são frequentes e dificilmente traduzíveis graficamente. Os inícios e finais devem ser simplificados em relação às possibilidades reais das práticas interpretativas das Caixeiras.

Todavia partituras podem apoiar a audição e a descrição do modo de produção da circularidade temporal presente nessa música que é feita pelo movimento integrado do instrumental, do canto e da dança no contexto no qual é produzida, e no qual pode ser compreendida.

Os elementos de análise musical usados neste trabalho pretendem compreender reinvenções presentes na relação da música com o roteiro ritual e não busca identificar elementos da música em si. Estas análises estão em estreita relação com o contexto no qual essa música é produzida. O material musical aqui apresentado e analisado tem informações relevantes para este momento e é também ponto de partida para outros e mais densos estudos sobre esse tema. 


\section{4 - Abertura da Tribuna: Espírito Santo Dobrado, ou Três Pancada.}

Maria Rosa, Caixeira que, entre outros Festejos, toca há muitos anos na Casa de Nagô, um dos Terreiros antigos em S. Luís, ensina a tocar e cantar: "Porque três pancada, já tá dizendo, que é pra descansar nas três pancada! Faz o primeiro verso e toca as três pancada, pra então repetir o segundo. Assim que ele fica bonito!"

Ela analisa a estrutura da música, desvendando sua organização no tempo. "Três pancada - primeiro verso - três pancada - repetição do segundo. Fica bonito!”, descreve, referindo-se à finalização da parte inteira. E ela destaca o descanso entre as partes do toque.

Maria Rosa nos inicia na compreensão de uma música construída pela adição de partes, da menor para a maior. Pequenas unidades que se agrupam para compor unidades maiores de duração, em uma concepção de adição e não de divisão.

Acrescento outras observações àquelas feitas por ela. Pancada é o ataque na pele do tambor e daí deriva seu significado. São três pancadas. Três notas tocadas com a mão principal, outras notas tocadas na borda da caixa e o tempo de descanso é a pausa entre cada conjunto de três pancada. Ao final uma variação: o dobrado.

A estrutura desta música se organiza por Toques, denominação que escolho por seu caráter êmico: é a denominação usual entre as Caixeiras.

Toque é o ciclo rítmico definido por Kazadi Wa Mukuna em seu trabalho Contribuição Bantu na Música Popular Brasileira de 2006.

Toque é também período, como Simha Arom identifica a recorrência de eventos similares a intervalos similares: um quadro temporal para os eventos rítmicos que têm na pulsação o ponto de referência. (Arom,1989 p. 91-92). Uma repetição periódica de uma sequência rítmica. Uma concepção circular de tempo na qual o fim de uma sequência de durações se une ao seu começo. 
A mesma questão foi elaborada por Ikeda, Dias e Carvalho no ensaio para o Projeto Cachuera!, de Música; Ritmo e Percussão ${ }^{20}$

A audição dos Toques à luz das observações das Caixeiras, em particular de Maria Rosa, aliada às reflexões de pesquisadores evidenciam o fato de que essa música não se relaciona a uma métrica baseada na acentuação de tempos fortes e fracos. Os ataques sempre coincidem com o pulso, e nenhum som produzido fora do tempo se sobrepõe à liderança da pulsação na organização rítmica. Ela se apoia em pulsações e não se observa variações do andamento, tempos rubatos, ou síncopas. $\mathrm{O}$ andamento é preciso, lento, compassado.

As notas tocadas pela mão principal têm sua intensidade aumentada e seu timbre alterado e por isso foram identificadas na transcrição pelo uso de sinais de acentuação. As notas tocadas com a outra mão, próximo à borda da caixa, são menos acentuadas e esse conjunto constroi o Toque. A transcrição inclui a melodia e o texto poético como apoio para evidenciar a relação do canto com a percussão, onde a análise tem seu foco. 


\section{Espírito Santo Dobrado}
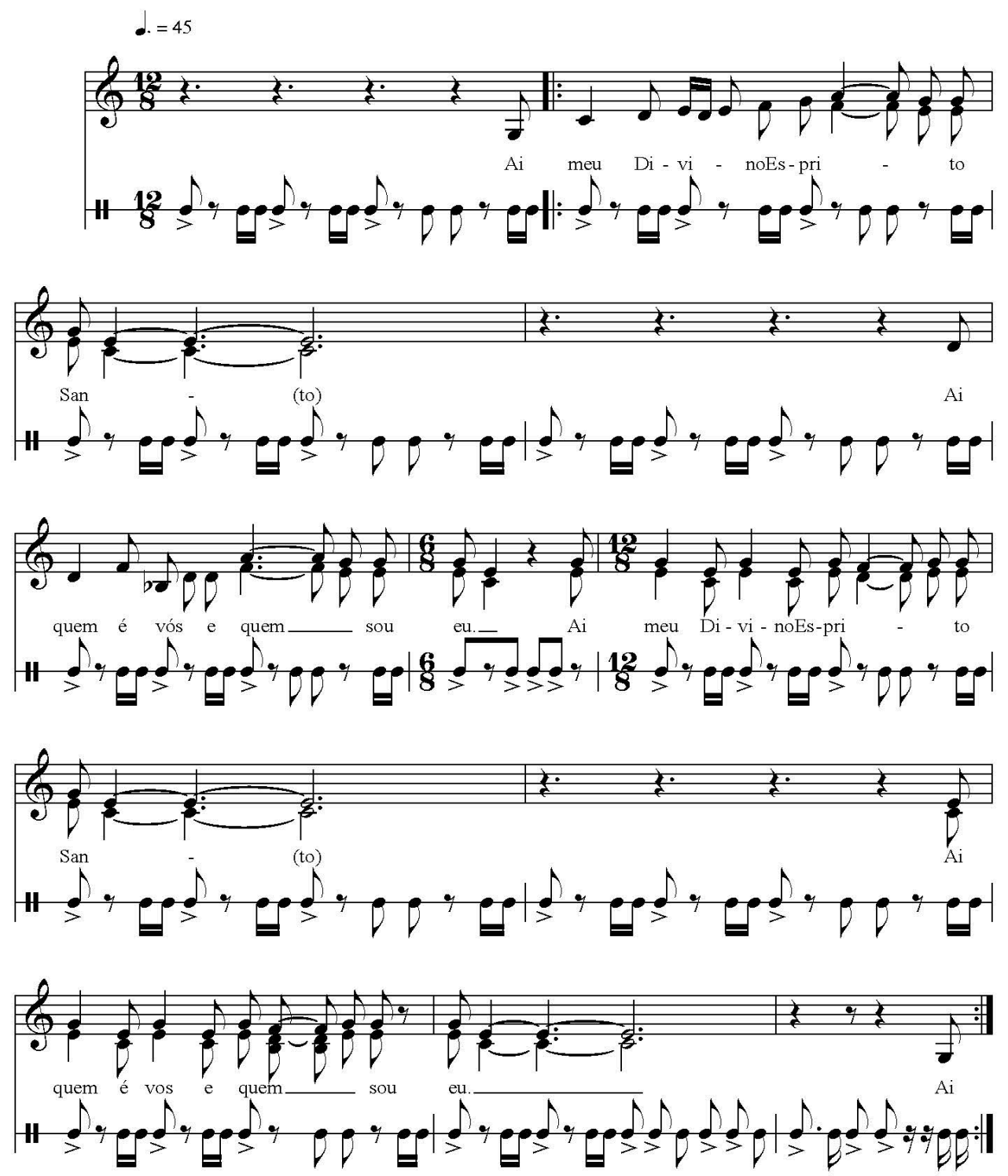

Figura 04 - Partitura do Espirito Santo Dobrado

Destaque-se que na transcrição em partitura, da figura 04, as hastes para cima destacam notas tocadas pela mão principal e as hastes para baixo distinguem as notas tocadas pela outra mão.

Observe-se a predominância do reaparecimento de material similar em intervalos regulares" presente na definição de período utilizada por Simha Arom "21 (AROM, 1989, p

${ }^{21}$ A period is a temporal loop based on " the recurrence of similar events at similar intervals" 
91). Tocado ininterruptamente, obstinadamente, em uma periodicidade estrita, os Toques têm raras variações e se estas ocorrem costumam ser previstas e feitas pelas Caixeiras mais experientes. Breves destaques ou divisões da pulsação em diálogo com as respostas, em coro, ao canto solo.

Na figura 05, está a transcrição de uma pancada:

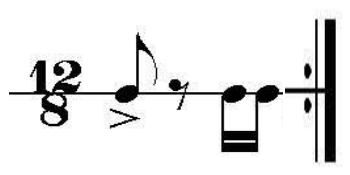

Figura 05 - Pancada

A tripla repetição dessa célula pode ser observada na figura 06 ,

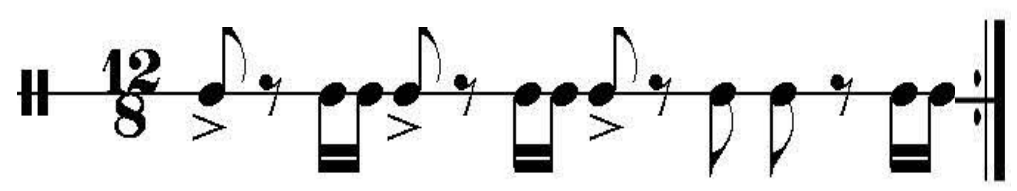

Figura 06 - Tripla repetição da Pacanda

Esta repetição constroi o Toque denominado Espírito Santo Singelo ou Corrido que acompanha muitos outros momentos rituais.

Três repetições deste padrão exposto pela figura 06, acrescido do dobrado (figura 07), abaixo representado, constroem o Toque Espírito Santo Dobrado ou, três Pancada.

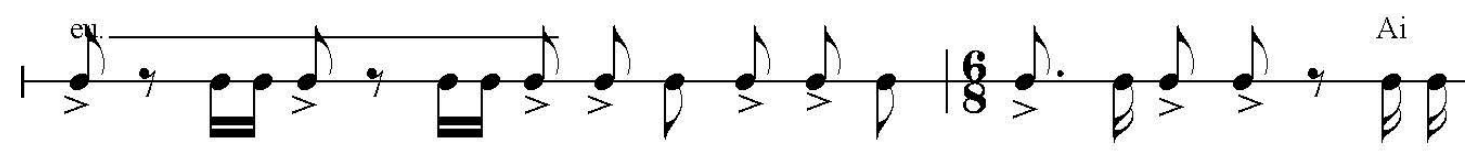

Figura 07 - Espirito Santo Dobrado ou Três Pancadas

A Caixeira Régia inicia e pode repetir o Toque se julgar necessário, até começar a cantar em um momento de respiração, proporcionado por um começo em anacruse, antes da 
primeira das três pancada. Canta dois versos e o coro os repete. O canto solo do primeiro verso ganha amplitude quando, no final da frase, outras Caixeiras cantam junto com a solista, adensando a linha melódica cantada por ela, com terças paralelas acima e abaixo da linha melódica.

Nesse processo alternam-se a voz solo que canta a linha melódica adensada e a resposta do grupo em coro, revelando em um movimento contínuo a estrutura de irmandade e cooperação presentes no canto. Essa estrutura é repetida até que todas tenham cantado seu verso, em uma reiterada alternância do lugar de solista. Durante a resposta do coro a solista canta no Baixão, destacando a melodia com essa voz.

A resposta do coro é anunciada e impulsionada por uma convenção na percussão que se soma ao canto, num movimento ascendente, conjunto e preciso, mantendo o dinamismo, criando brilho e um sentimento de expansão em um diálogo que segue compassadamente. A figura 08 reproduz a convenção referida, que está na terceira linha da percussão e, compreendida em 6/8, pode-se observar sua relação com o canto.

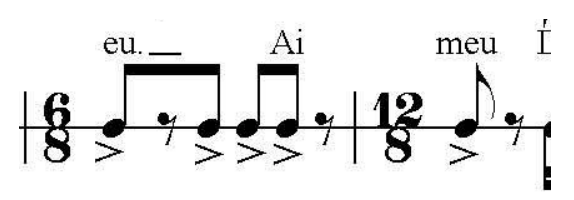

Figura 08 - Conveção para resposta do coro

Apresento uma representação gráfica da estrutura do canto com o exemplo de uma das quadras do repertório desse toque. Destaco frases e palavras que, ao final dos versos, são cantadas simultaneamente em terças acima e abaixo da linha melódica pelas outras Caixeiras que apoiam a solista, em um processo de adensamento da linha melódica. 


\section{Gráfico:}

\section{Grupo 1 - Solista canta dois versos com apoios:}

(terça acima) prito Santo

(solista) Ai meu Divino Esprito Santo

(terça abaixo) prito Santo

solador

Ai Divino consolador

solador

\section{Coro responde aos dois versos em três vozes}

(terça acima)

(solista)

(terça abaixo)
Ai meu Divino Esprito Santo

Ai meu Divino Esprito Santo

Ai meu Divino Esprito Santo

Ai Divino consolador

Ai Divino consolador

Ai Divino consolador

Solista canta os dois versos seguintes com apoios:

minha alma

Ai consolai a minha alma

minha alma

mundo for

Ai quando desse mundo for

mundo for

Coro responde aos dois versos em três vozes

Ai consolai a minha alma

Ai consolai a minha alma

Ai consolai a minha alma

Quando desse mundo for

Quando desse mundo for

Quando desse mundo for 
A precisão da execução musical cria a ambiência e a beleza do ritual e inclui essa diversificação polifônica. Todos os cuidados com a realização desse culto festivo se alinham à preocupação que seja bem recebido pela divindade, que a Casa e a comunidade sejam abençoadas com uma vida harmoniosa e plena de realizações.

Aberta a Tribuna no sábado de Aleluia com o Toque Espírito Santo Dobrado, as Caixeiras reúnem-se todos os domingos à tarde em cantorias para o Divino, até o início do Festejo no mês de julho, quando o Mastro será levantado. Os preparativos se iniciam com a busca do pau no mato, e sua sacralização pelo batizado.

\section{5 - O Mastro!}

O Mastro é feito com uma árvore de tronco sem galhos, ereto, e deve ser alto e visível desde longe, pois identificará o endereço do Festejo. Será o Guia.

Em Festejos na zona rural, a busca e corte do pau no mato é uma parte importante do ritual e é também acompanhado pelas Caixeiras. Contemporaneamente, esse é um processo longo que se inicia com pedidos de permissão aos órgãos responsáveis pela gestão ambiental local. No caso de um Terreiro urbano, como a Casa Fanti Ashanti, trata-se do buscamento de um Mastro deixado em outro lugar para que se realize a procissão pelas ruas. Antes de ser batizado, ele ainda é o pau. Depois será o Mastro.

O pau é colocado sobre suportes que o mantêm suspenso. Ele só tocará a terra na vertical. Sobre esses suportes, ele é batizado em uma cerimônia que o sacraliza. Madrinha à direita e padrinho à esquerda, do ponto de vista de quem está aos pés do Mastro. Cada qual segura a ponta de um tecido rendado branco que paira sobre ele. O padrinho segura um copo com água que a madrinha utiliza para borrifar no Mastro com um ramo verde, enquanto circulam ao seu redor. Começam pelo alto e ao chegar aos pés, mudam de lado, e a madrinha sobe à esquerda. Em seguida, o par de padrinhos derrama sobre ele vinho tinto, sanguíneo. Ficam sempre um de cada lado, percorrendo-o e banhando-o em toda a sua extensão, mudando de lugar e tornando a percorrê-lo e banhá-lo, de modo que o pau seja depositário da presença de homens e mulheres. Depois desse processo que o sacraliza, ele é o Mastro. O restante do conteúdo da garrafa é despejado no buraco no qual será enterrado. E enquanto batizam-no, segredam-lhe: 
Eu te batizo oliveira

Com toda a sua formosura

Não te dou os santos óleos

Porque não és criatura

O Mastro batizado costuma receber um nome escolhido por seu padrinho, um nome ligado à natureza, reatando laços com o mundo do espírito. Nomes como Alegria da Mata, Oliveira Santa, Escada do Céu. "São metáforas poderosas, que remetem a imagens arcaicas de um mundo onde o feminino ainda é percebido como veículo essencial de expressão do sagrado". Essa afirmação de Maria Lucia Montes em texto para o encarte do segundo CD gravado pela Associação Cultural Cachuera!. (MONTES, 2011, p. 14) enfatiza o protagonismo das mulheres na liderança destes festejos.

Um cortejo vai pelas ruas até o local onde o Mastro foi preparado, batizado e aguarda o cortejo que irá buscá-lo para ser levantado na Casa Fanti Ashanti, há pouco mais de um quilometro dali. Essa distância permite a existência do cortejo para buscá-lo e trazê-lo pelas ruas, para que possa ser visto, visibilizando também a Festa.

Este cortejo é liderado pelo Bandeireiro à frente, empunhando o Estandarte, imediatamente seguido pelo Império e visitantes da Casa. As Caixeiras vão atrás, tocando e cantando. Na chegada do cortejo à casa, a Caixeira Régia canta pedindo licença para entrar com o Toque Espírito Santo Dobrado.

Na sua porta senhora

Aí parei meus instrumentos

Eu lhe trago retratado

O Santíssimo sacramento

Dê-me licença senhora

Ai dê-me licença inteira

Ai dê-me licença que eu entre

Ai com as minhas companheira

Senhora dona da casa

Ai com vós eu quero falar 
Venho buscar o oliveira

Pra de tarde enterrar

Um Altar foi montado ali e o cortejo entra com as Caixeiras cantando e salvando o Divino, ali representado. Ao final, a Dança das Caixeiras.

Em pé, em formato de meia lua em frente ao Altar da Santa Crôa e começando pela Caixeira Régia, cada uma delas vai tocando, cantando e dançando sozinha até o Altar e cumprimenta o Império e o Divino com uma pequena flexão de joelhos. Voltando para o grupo que está em meia lua, um pouco distante do altar, ela para em frente à próxima Caixeira, em sentido anti-horário, e a convida para ir cumprimentar o Império, com a mesma flexão de joelhos em um momento preciso, ao final da célula rítmica que está sendo tocada. Ambas giram em torno de si próprias, cumprimentam-se repetindo esse movimento de flexão, e a outra Caixeira sai e ela retoma seu lugar. Assim se segue até que todas tenham ido pessoalmente saudar o Divino e o Império. Para finalizar, dançam todas ao mesmo tempo pela sala, cumprimentando-se aleatoriamente com essa mesma flexão e finalizam rufando suas Caixas, desfazendo a ambiência criada anteriormente pela música.

O Toque desse momento é o Dança das Caixeiras, cujo repertório tem versos de elogio, amizade e camaradagem;

Caixeira que tá dançando

Corra a mão no seu cabelo

Que do céu já vem caindo

Pinguinho de água de cheiro

Sapateia sapateia

Sapateia no tesouro

$\mathrm{Na}$ barra do seu vestido

Brilha prata e brilha ouro

$\mathrm{Eu}$ conheço esta senhora

Mas não sei dizer d'aonde

Lá do céu atrás das nuvens

Onde as estrela se esconde 
Senhora dona da casa

Deus lhe dê muito obrigado

Obrigado ao Oliveira

Ai que bonito aquele pau

Param para um breve descanso, para esfriar os corpos suados pela caminhada sob o sol forte, servem-se refrigerantes e água e todos se preparam para a volta para a Casa Fanti Ashanti, levando o Mastro. Os homens o carregam e as Caixeiras cantam botando versos sobre o tema.

\author{
O Mastro de Espírito Santo \\ é de pau de mururé \\ é carregado por homem \\ festejado por mulher
}

Arreda povo arreda
Deixa os Império passar
Passa a Crôa, passa o cetro
Passa a bandeira riá

As Caixeiras tocam e cantam todo o tempo até chegar à Casa. O Mastro é novamente colocado sobre suportes que o mantém distante da terra. Caixeiras e o Império, formado pelas crianças, circulam-no por três vezes no sentido anti-horário e ao final colocam-se ao lado, em meia-lua, para que o processo de levantamento do Mastro, ritual do qual os homens se ocupam, tenha seu início. Moisés Espírito Santo identifica nestes "ritos deambulatórios" 22 uma tradição de origem semita. (ESPÍRITO SANTO 1985, pp. 159-163)

O sentido anti-horario é também a direção das danças e festejos de culturas negras, indígenas e de outros povos antigos no Brasil e no mundo. As rodas de ciranda, capoeira, Candomblé, Tambor de Mina, para citar algumas, os giros dos Derviches Sufi, também se orientam por essa direção. As Caixeiras para as quais perguntei o sentido dos giros no sentido anti-horário, não reconhecem nisso nenhum significado específico, embora todas as festas os

\footnotetext{
${ }^{22}$ A direção anti-horario unifica as danças tradicionais de matriz Africana, Judaica e Sufi, para citar algumas. Essa é a direção na qual a terra gira ao redor de si no movimento de rotação.
} 
realizem dessa forma. Esse costume está presente como parte da memória da festa e integram o conjunto de práticas e significados presentes naquele universo e no universo dos Terreiros, onde todas as rodas giram nessa direção.

O Mastro tem, em sua parte superior, o Mastaréu, uma estrutura que emoldura e mantém aberta uma bandeira com a imagem do Divino: o(a) pombo(a) branco(a) com asas abertas, ou uma coroa dourada. Logo abaixo, vem um suporte sobre o qual se coloca cuidadosamente um bolo de tapioca redondo. Esse bolo, sacralizado por sua proximidade com a morada do Divino, terá seus pedaços distribuídos entre pessoas escolhidas, quando o Mastro for derrubado no final do Festejo.

O levantamento do Mastro é feito com o apoio de tesouras feitas com varas amarradas em X para sustentar seu peso. Esse é um momento carregado de tensão e preceitos a serem observados. Pai Euclides dá a sua versão:

Porque muitas das vezes o Mastro vai levantando, e acontece alguma coisa e ele voltar, e cair, pode contar que coisa boa não vai acontecer com alguém da festa. Se é no fechar da Tribuna, erra o bendito, pode contar... Vários sinais que o Divino mostra e a gente não quer ligar, e não é superstição, não!

...Nós fizemos a festa do Espirito Santo aqui, e nós levantamos o Mastro. Assim que ele se equilibrou e caiu no fundo do buraco, o Pombo caiu lá do topo do mastaréu, e um garoto pegou e saiu de carreira com ele aqui, (embaixo do braço). Saíram correndo atrás, e trouxeram o Pombo. Só que não se pôde colocar ele de volta a seu lugar porque o Mastro era muito alto, e aí amarraram ele acima da metade. Isto foi em julho, e quando foi em novembro a minha mãe, que era a Caixeira Régia da casa, faleceu. Isto foi um sinal!

\section{5 - Levantamento do Mastro - O Toque? Nossa Senhora da Guia}

O Nossa Senhora da Guia é um Toque ternário que acompanha os rituais relacionados ao levantamento e derrubamento do Mastro. Ele tem, em seu repertório, versos nos quais se observa a identificação do Mastro com a Estrela Guia: Estrela d'Alva, Estrela da manhã, Vênus.

Guia de quem procura a festa, o Mastro deve ser visto de longe. Os versos do repertório associam essa característica à visão de aproximação de um navio que chega de longe e o repertório indica Portugal como o lugar de origem dessa embarcação. 
Lembro aqui que Donald J. Grout e Claude Palisca atribuem a denominação perfectus para os modos rítmicos ternários, que predominavam na música medieval até o século XIV, possivelmente em razão de sua associação com a Santíssima Trindade. (Grout et Palisca 1994, p 104). Esta afirmação é reiterada por Marianna Monteiro e Paulo Dias em artigo sobre música popular tradicional brasileira e acrescentam que "os ritmos em dois ou quatro tempos eram imperfectum”. (MONTEIRO e DIAS, 2010, p. 355).

\section{Nossa Senhora da Guia}
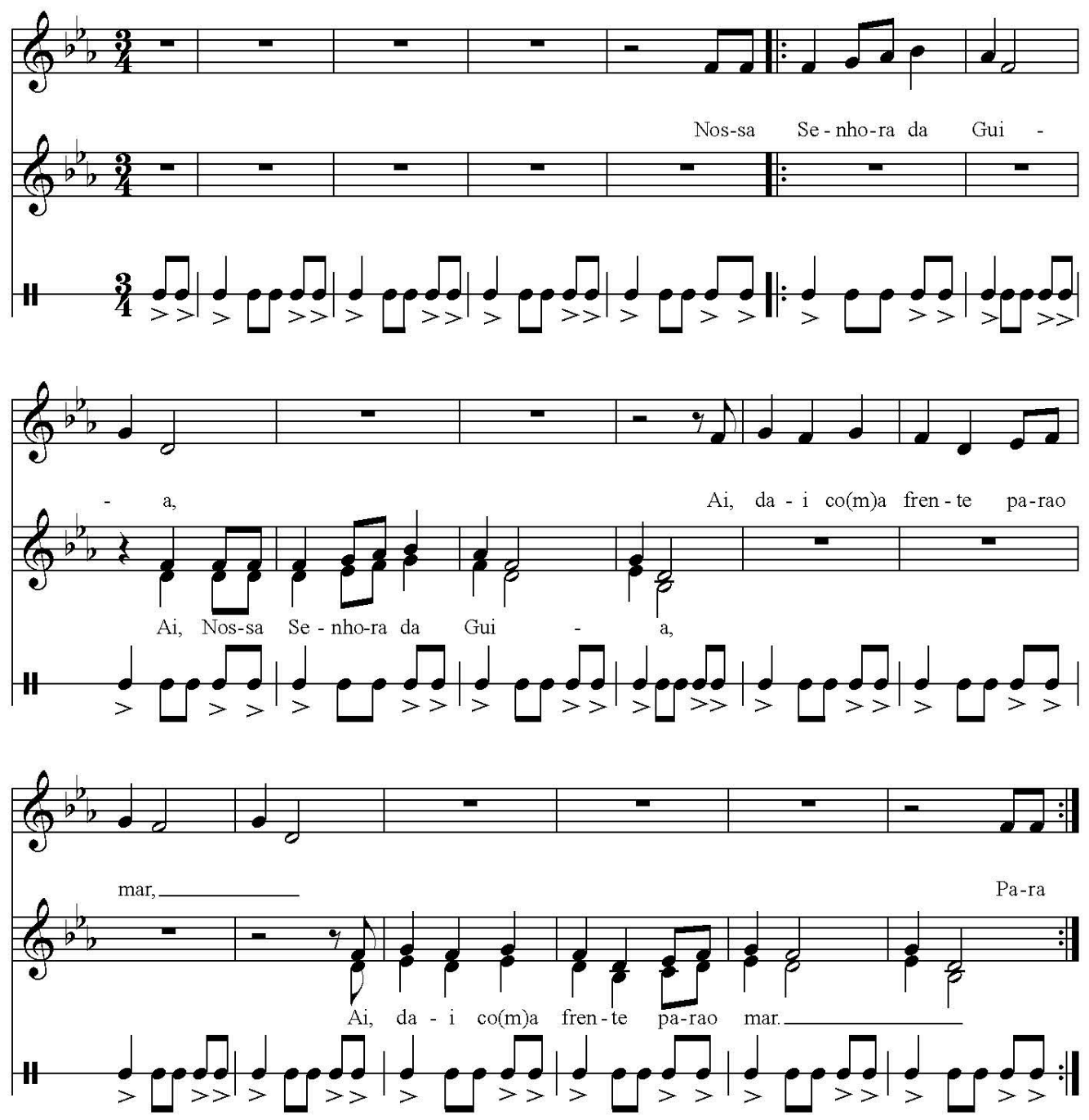

Figura 08 - Partitura de Nossa Senhora da Guia 
Daí com a frente para o mar

Para ver seu bento filho

Quando vem de Portugal

Nossa senhora da Guia

Me empreste o vosso manto

Eu quero subir ao céu

Domingo de Esprito Santo

Quando o Mastro for acima

Eu quero ser a primeira

$\mathrm{Eu}$ quero pegar nas asas

Do pombinho verdadeiro

Que bonito pé de árvore

Ai que a natureza criou

Ai pra servir de Mastaréu

Ai na festa do Imperador

Que bonito pé de arvore

Ai que nasceu pra ser feliz

Ai pra servir de Mastaréu

Ai na festa da Imperatriz

Nossa Senhora da Guia

É a mesma Conceição

Nos valei-me a Senhora

Em todas ocasião

Nossa senhora da Guia

Me empreste vossa coroa 
Meu Divino Espírito Santo

Que vem vindo de Lisboa

A Caixeira Régia canta e o coro responde a cada um dos versos, até o final dos quatro versos que compõem a quadra. Durante a resposta do coro, a solista canta no Baixão e é acompanhada por outras que saibam cantar essa voz.

Nesse momento, a paisagem sonora está repleta de sons. Pessoas conversam, homens trabalham com pás, retirando terra no processo de ajuste do tamanho do buraco para o Mastro. Tudo está em perfeita consonância com o momento. As Caixeiras estão juntas em semicírculo, em uma pequena área e ao cantar seu verso devem fazê-lo alto e claro, sob pena de não conseguirem ser ouvidas pelo grupo. Elas costumam cantar projetando sua voz alto e longe, além de saber usá-la para cantar durante muito tempo. E àquelas que não conseguem cantar colocando a voz no mesmo lugar, elas ensinam:

$$
\begin{aligned}
& \text { O cantar não é de força } \\
& \text { não é preciso forcejar } \\
& \text { abre a boca e a garganta } \\
& \text { deixa o peito soluçar }
\end{aligned}
$$

A presença das Caixeiras acontece e encontra sua força no coletivo identificado pelo som das caixas e cantos em uníssono que se alterna com momentos solo. Destaca-se a irmandade das Caixeiras.

Mas, a leitura e reflexões do estudioso da voz, Paul Zumthor em Performance, Recepção e Leitura nos apoia a observação das performances pessoais destacando presenças, sentimentos e disposições individuais. O autor dialoga com pesquisadores, etnólogos, entre eles, Alan Lomax, cujo objeto de estudo são manifestações culturais às quais Zumthor denomina lúdicas que estão em estreito diálogo com estudos de comunicação oral engendrando contextos reais.

As Etnografias da música nas culturas de predominância oral, como o é o universo das Caixeiras, buscam refletir e ampliar o contexto no qual ela é produzida, para que este possa ser lida percebido em sua dimensão, lugar, e em sua forma. Para que isto seja possível é preciso um trabalho pedagógico para tornar esse universo apreensível. Este processo costuma exigir que ele seja decomposto, analisado segundo sua estruturas de versificação, percussão, melodias e outros parâmetros que podem ser eleitos. Zumthor destaca que estes 
procedimentos fragmentam-nas, negando sua forma essencial, o conjunto expressivo, a performance.

Essas manifestações emergem do contexto reconhecido e é performance este saber que comanda uma presença, uma conduta comportando coordenadas espaço-temporais e fisiopsíquicas concretas; uma ordem de valores encarnada em um corpo vivo. (ZUMTHOR, 2000).

Desse modo o autor chama a atenção para o fato de que a pragmática, interessada nas relações entre os signos e seus usuários, concentra sua atenção nos fatos sociais e não consegue incluir a experiência individual e o prazer experimentado na performance, para atingir, talvez, ao final de percurso, o ritual coletivo. (ZUMTHOR, 2000)

O Levantamento do Mastro chega ao final e ele já foi colocado de pé, ereto e firme. Acende-se, então, uma vela ao seu pé e se festeja com rufos de Caixas, vivas e palmas! Nesse momento, pequenos bolos de tapioca começam a ser jogados do alto, da beirada da Casa para o público, as pessoas se acotovelam para apanhá-los, rindo, brincando, limpando a poeira grudada neles e, claro, comendo.

Quem subiu na beirada da Casa para lançar os bolos para o povo foi um grande personagem da festa, o Encantado ${ }^{23}$ Antônio Luís Corre-Beirada, grande cantador. Carregado por Pai Euclides, encanta a quem o rodeia para vê-lo improvisar versos e dançar elegantemente, usando seu chapéu.

O Levantamento do Mastro inclui sempre o Tambor de Crioula por toda a noite. A parelha formada pelos tambores grande, meião, crivador, estão sendo afinados pela fogueira acesa. Aquecidos os tambores, a roda é formada pelas coureiras que dançam e outros que cantam ou assistem.

A vigília acontece durante toda a noite com a força do Tambor de Crioula. No dia seguinte, às 6 seis horas, as Caixeiras saem da roda que se manteve durante a noite toda e se dirigem ao Mastro para cantar uma Alvorada. Durante toda aquela semana, até o dia da Festa Grande, no domingo da semana seguinte, as Caixeiras cantam alvoradas para o Divino diante do Altar ainda provisório. No próximo domingo pela manhã, o festejo é retomado com uma Alvorada para o Mastro. O Toque? Alvorada.

\footnotetext{
${ }^{23}$ Em Desceu na Guma, trabalho sobre a Casa Fanti Ashanti, Mundicarmo Ferretti analisa a relação entre esta entidade Antônio Luís Corre Beirada e Pai Euclides que o carrega.
} 


\section{6 - Alvorada}

O Alvorada é um momento ritual ao qual o Toque estreitamente ligado a ele recebe o mesmo nome e é também tocado durante as visitas ao Império do Divino, representado pelas crianças. Momentos importantes que compõem a estrutura da festa.

Para a compreensão do Toque Alvorada trago uma fala de D. Celeste Santos, organizadora do Festejo do Divino na Casa das Minas por mais de 30 anos e hoje já falecida.

A Alvorada é um toque principal, tocado de madrugada, na noite da Festa, se toca ao meio-dia, de tarde e se toca na hora que vai visitar os Impérios. Só (para) os Impérios que (se) toca a Alvorada. Então tem que tocar sempre a Alvorada.

Todas as vezes que começar a tocar nos dias que não é o dia da Festa que chega as seis horas ou meio dia, tem que ter o toque de Alvorada. Alvorada completa. Que ela tem um dobro no meio que se chama Alvoradinha mas no mesmo toque.

A audição da música para o Divino nos remete a um universo de grande densidade sonora e o cantar das Alvorada é majestático, com um andamento lento para o canto e a percussão dos tambores. Uma sonoridade que não se ressente da ausência de outros instrumentos. Os toques em uníssono reiteram a igualdade das Caixeiras em torno da devoção ao Divino, "trazendo a experiência de uma produção comunal do tempo, uma prática estranha à pragmática capitalista no mundo da propriedade privada" (WISNICK 1989. P.78) 


\section{Alvorada}
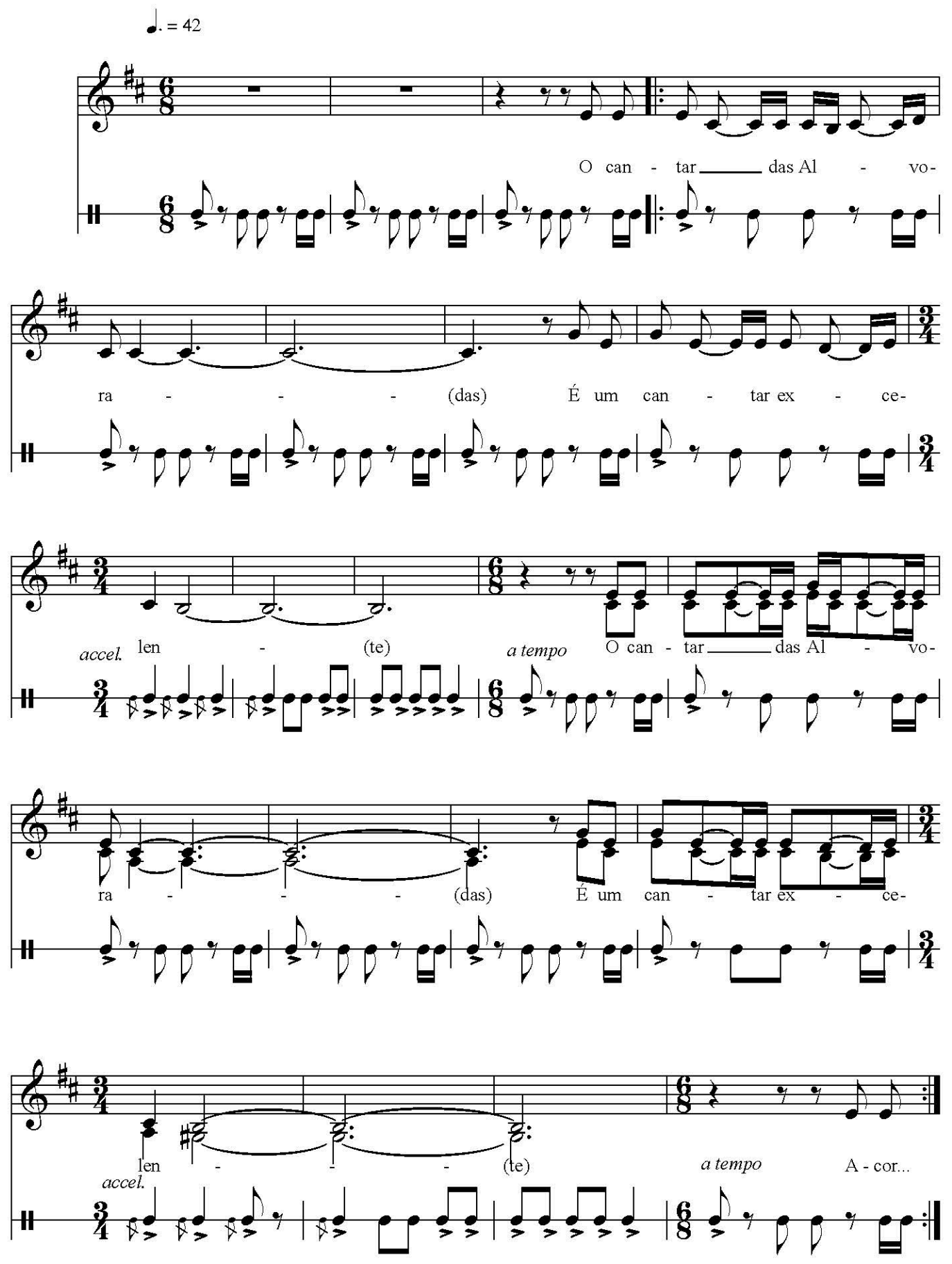

Figura 09 - Partitura do Toque Alvorada

Ressalto que o uso de sinais de acentuação na transcrição da percussão tem o papel de destacar o traço estilístico construído pela acentuação natural das notas executadas pela mão principal, destra ou canhota. 
Ao iniciar uma cantiga, cada Caixeira o faz em uma altura adequada a seu conforto e as outras a acompanham. Quando outra Caixeira botar sua cantiga, ela fará o mesmo. Oliveira Pinto nos chama a atenção para o fato dos ouvidos habituados a certas relações de intervalos, afinações e outros determinantes presentes na música ocidental, costumarem corrigir, automaticamente, o que compreendem como desafinações. $\mathrm{O}$ autor nos lembra que a noção de afinação é um conceito etnocêntrico, apoiando-se em normas do mundo musical, próprio à música canônica, para compreensão de universos diferentes dos seus.

“Quando uma pessoa do centro da África vai cantar em grupo na condição de líder, ela inicia o canto na altura confortável para a projeção de sua voz. As outras pessoas cantam em paralelo, ouvindo a linha que ela lidera e cantando em alturas confortáveis para si mesmas" Disse o etnomusicólogo Kazadi Wa Mukuna em oficina no Encontro de Culturas Tradicionais na Chapada dos Veadeiros em Goiás, no ano de 2008.

O Toque Alvorada inclui também um dobrado. O som dos tambores mantém constante o pulso nessa variação. $\mathrm{O}$ canto se organiza por sílabas que se estendem sobre o som grave e uníssono das caixas tocando o dobrado. A sensação é de gravidade majestática quando em seguida, o canto reencontra a percussão no terceiro verso do poema estruturado em quadras.

Essa música estabelece relações entre as sílabas tônicas do poema e os pulsos naturalmente acentuados da percussão. No Toque da Alvorada, obedece a padrões rítmicos binários compostos e ternários, construindo a circularidade, elemento musical importante e constituinte dessa música.

Observa-se que a presença de diferentes ordenamentos dos pulsos em um mesmo Toque, a passagem por todos eles e um reinício, proporciona uma sensação de ordenação do mundo: uma respiração.

O Toque Alvorada, do mesmo modo que o Espírito Santo Dobrado, se constrói pela soma de padrões:

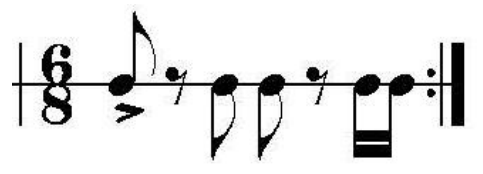

Figura 10 - Toque Alvorada 
E inclui outro em $3 / 4$, o dobrado. O Toque é construído pelo ciclo completo. Inclui o primeiro pulso do padrão em 6/8 do compasso seguinte, conectando o início do canto do próximo verso à repetição do Toque e construindo a circularidade observada nessa música.

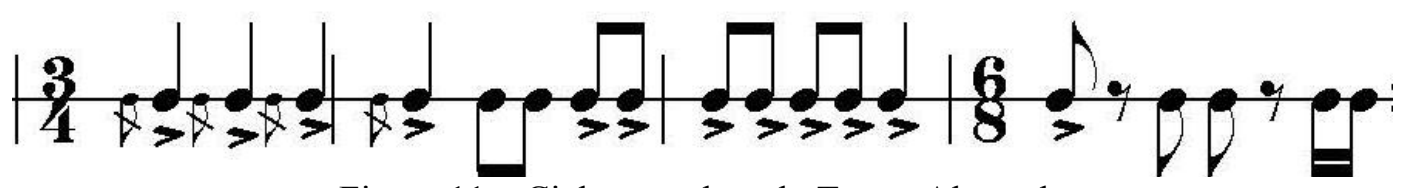

Figura 11 - Ciclo completo do Toque Alvorada

O Toque se relaciona diretamente a dois versos cantados, a cada vez, pela voz solo. A mesma estrutura se repete na resposta do coro, quando a voz que cantou solo canta no Baixão. As Caixeiras conhecem a grande importância dessa voz no destaque da melodia. O Baixão geralmente se estrutura por terças paralelas, inferiores à voz principal, e este conceito no universo das Caixeiras, inclui também o andamento lento, compassado.

Por sua dificuldade de realização, torna-se referência para a excelência. As Caixeiras que cantam no Baixão são valorizadas. Maria Rosa ensina:

No interior elas canta no Baixão, num canta assim alvoraçada... A cantiga pode num ter pé, ser simples sem nada, mas elas capricha no Baixão! Cantiga de Esprito Santo quanto mais no Baixão é melhor. É mais bonito! Pra quem não tem voz, eu canto com aquela vozinha enjoada, a senhora faz o Baixão, me ajuda...

De manhã o sol é rei

Meio dia é reis croado

Às quatro hora ele é morto

Às seis hora é sepultado.

O cantar das Alvorada inicia o canto nesse momento do ritual, na Casa Fanti Ashanti. Alvorada celebra momentos importantes das sequências rituais. As horas fortes: nascer do sol; meio dia; dezoito horas; e, antigamente, em Alcântara, à meia-noite.

As celebrações dos ciclos do dia, dos ritmos da natureza que engendram estações, ciclos de produção agrícola, de abundância ou carência, foram incorporadas à liturgia cristã na idade média. Sob o nome de Ofícios ou Horas Canônicas, afirmam que a recitação pública dos cantos, associados às horas fortes, é geralmente observada nos mosteiros, igrejas e 
catedrais. São elas; as matinas ${ }^{24}$, antes do nascer do sol; as laudas, ao alvorecer; prima, terça, sexta e nona, respectivamente às 6 da manhã, 9 da manhã, meio-dia e três da tarde; vésperas, ao pôr do sol; e completas, em seguida às vésperas. . (GROUT e PALISCA, 1994, pp. 51-52)

Nenhuma referência ao canto nas horas da noite, mas D. Raimunda Soares, Raimunda Boró, antiga Caixeira Mor em Alcântara, referiu-se a esse canto da Alvorada à meia-noite.

Dantes se tocava Alvorada de madrugada debaixo do Mastro. Quando se tocava e tinha Mastro, eu vinha em casa 4 horas: - Minha gente, vim só dizer a vocês que só venho de manhã! Eu nunca gostei de andar de noite! Lá mesmo, quando a gente saía da igreja e ia pra casa dos Império, lá mesmo tocava Alvorada até meia-noite. Quando era meia- noite, batia na Caixa...

Galo preto já cantou

Em sinal de amanhecer

Se galo preto soubesse

Quanto custa um bem querer.

As horas da noite como momentos de celebração são encontradas na cosmogonia do povo Bakongo. Segundo Maria Lucia Montes ${ }^{25}$, os Bakongos vieram para o Brasil provenientes da costa ocidental da África Central e integram a civilização chamada Kongo, para se distinguir da cultura do antigo Congo, fruto do colonialismo europeu. (MONTES, 1997)

Montes ensina que esse povo compartilhava formas culturais e conceitos religiosos com povos provenientes de regiões que hoje incluem o Zaire, Cabinda, Congo Brazzaville, o noroeste do Gabão, e o norte de Angola, na região de Benguela.

Analisando a cosmogonia dessa civilização, a autora destaca a associação aos ciclos aparentes do sol visto da terra; o sol morre ao entardecer, quando penetra e transita no Kalunga, o reino dos mortos, e renasce igual a si mesmo todos os dias, em clara associação à continuidade da vida dos seres humanos. Ao meio-dia, o sol a pino simboliza a masculinidade e o auge do poder de uma pessoa na terra. Esse ciclo de morte e renascimento tem na noite a associação ao feminino e na meia-noite, ao máximo poder sobrenatural de uma pessoa.

\footnotetext{
${ }^{24}$ As matinas incluem alguns dos mais antigos cantos da igreja, e as completas têm como seu aspecto característico o canto de saudações à Virgem Santa Maria. E um deles, o Regina caeli laetare (alegrai-vos rainha dos céus) é cantado da Páscoa até o Domingo da Trindade, o primeiro depois do Domingo de Pentecostes.
} 
Essas pontuações evidenciam construções sociais liminares, em reforços mútuos, construindo um desenho orgânico. E aqui penso com Antonacci, quando destaca que "de imprevisíveis e impensáveis formas, reativam ancestrais forças e recursos de identificação e intercâmbio, em sinais de renovação de suas tradições" (ANTONACCI, 2013, p. 152). Tradições cujos significados e importância para o conjunto social se revelam nas presenças e continuidades, nas repetições, nas ausências, nos esquecimentos e abandonos.

O Cantar das Alvorada, nos festejos de Espírito Santo, tem seu início dado pela disponibilidade das Caixeiras presentes, mas é senso comum cantar antes das 6h, pela manhã. Ao redor do Mastro ou em frente ao altar do Divino. Eu o vivenciei em Alcântara por volta de 4:30h. Antes das primeiras rachaduras na noite, provocadas pela luz da Alvorada que coroa a terra, as Caixeiras já estavam cantando e tocando ao redor do Mastro que havia sido levantado na tarde anterior. Continuaram enquanto o dia clareava, até que o sol aparecesse por completo.

O cantar das alvorada

É um cantar excelente

Acorda quem está dormindo

Alegra quem está doente

Se alevanta foliôa

Senta o pé na terra fria

Vem ouvir cantar alvorada

Na capela de Maria

Levantei de manhã cedo

Fui varrer a conceição

Encontrei Nossa Senhora

Com seu raminho na mão

Eu voltei pedi a ela

Ela me disse que não

Eu voltei tornei pedir

Ela me deu seu cordão 


\author{
Galo preto já cantou \\ É sinal que amanheceu \\ Bota milho no terreiro \\ Pro galo preto comer
}

\begin{abstract}
Alvorada é tão bonita
Quando vem rompendo o dia

Deus vos salve espírito santo

Filho da virgem Maria
\end{abstract}

No pino das 12 horas, nova Alvorada para o Mastro ou para o Altar. O repertório continua a destacar a hora do sol. A recorrência diária do cantar nas horas fortes sacraliza-as pela sua "capacidade de invocação da ordem," que também é invocada ao produzir-se e manter--se um toque ritmado, construído coletivamente.

Foi agora que eu cheguei

No pino das 12 horas

Vou salvar Esprito Santo

O Divino rei da glória

Ás 18:00h. Outra Alvorada para o Mastro ou para o Altar:

É 6 horas é 6 horas

Hora de dizer amém

Já ouvi tocar o sino

$\mathrm{Na}$ igreja de Belém

Quem me dera se eu pudesse

Fazer do dia maior

Dava um nó na fita verde

Prendia o raio do sol

o sol posto vai doente

se não sangra ele morre 
que o sol é como o sangue

que por toda veia corre

Depois que todas as Caixeiras "botaram" seu verso, a Caixeira Régia começa a dobrar a Alvorada. É a hora da Alvorada Dobrada ou Alvoradinha.

\section{7 - Alvoradinha ou Alvorada Dobrada}

Alvoradinha é um Toque que sucede o Alvorada em sequência e estreito diálogo. Ambos têm cantigas que se referem ao ciclo aparente do sol e seu movimento. Ao final do Alvorada, e por uma adaptação rítmica na percussão que as Caixeiras denominam dobrar, passam a tocar o Alvoradinha. 
Alvoradinha

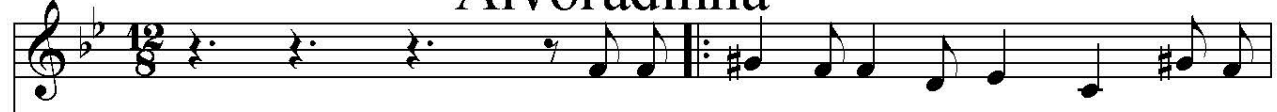

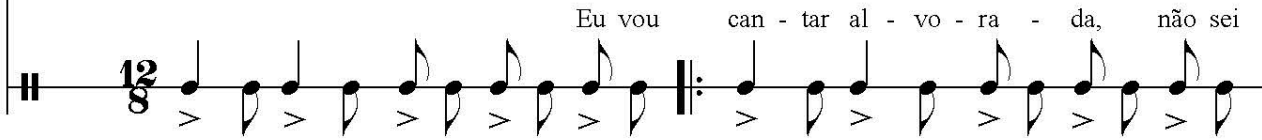
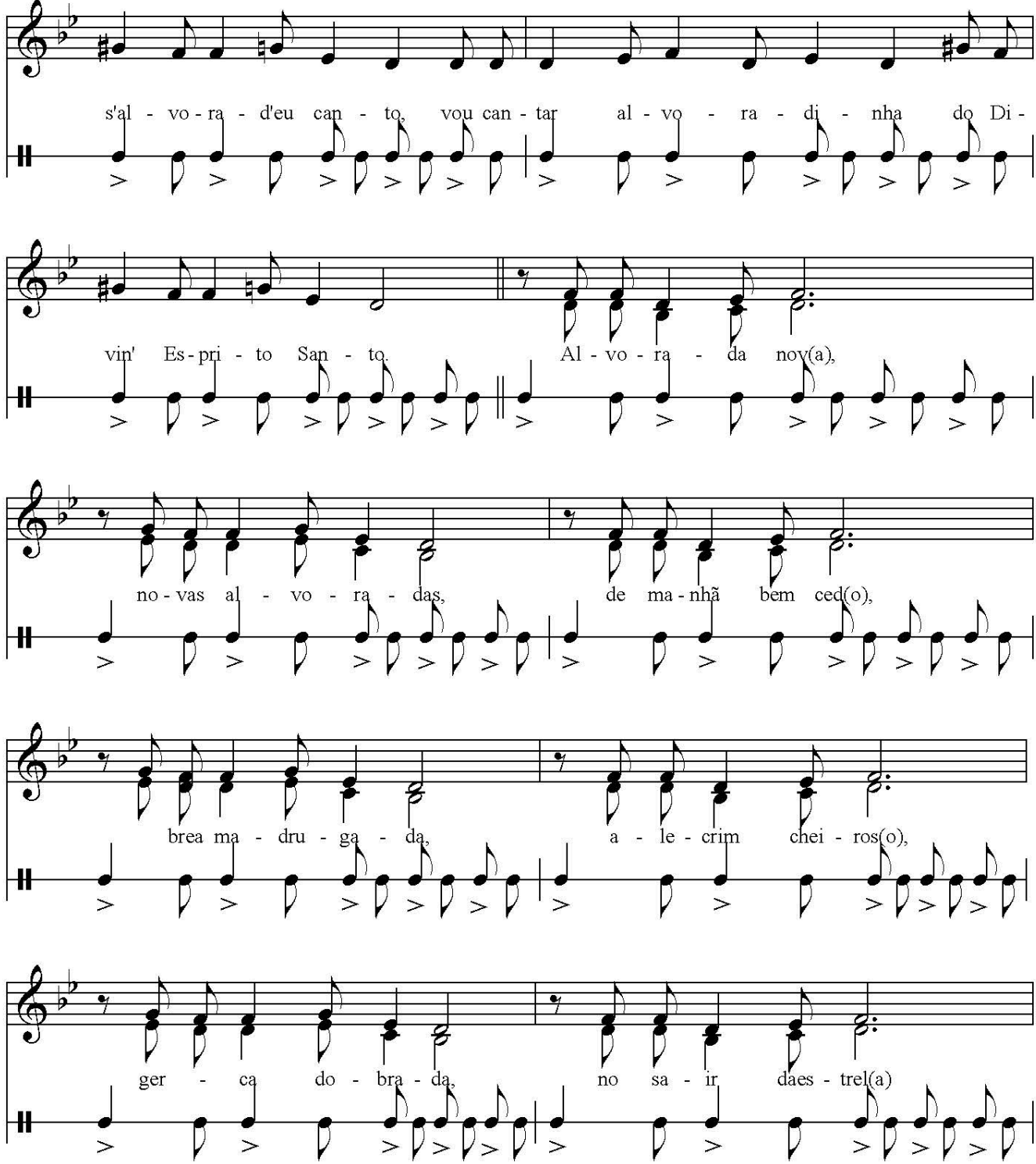

C)

Figura 12 - Partitura de Alvoradinha 
Aqui temos presença da hemíola estruturando o Toque. Um ternário simples e um binário composto em uma mesma célula que se estrutura por assimetria regular, baseada na repetição desta configuração em uma figura rítmica. (AROM 1989, p. 96).

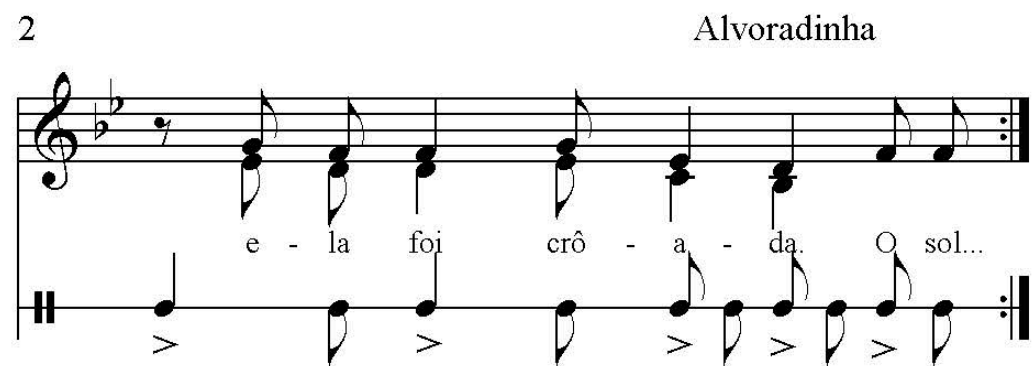

Figura 13 - Hemíola no Toque Alvoradinha

Eu vou cantar Alvorada

Não sei se Alvorada eu canto

Vou cantar Alvoradinha

Do Divino Esprito Santo

Refrão cantado depois de cada quadra solo:

Alvorada nova

Novas alvorada

De manhã bem cedo

Sobre a madrugada

Alecrim cheiroso

Angerca $^{26}$ dobrada

no sair da estrela

ela foi croada

$\mathrm{O}$ sol pensa que me engana

Trago ele a meu jeito

Ele sai eu me levanto

${ }^{26}$ Angélica é uma flor 
Ele se põe eu me deito

De manhã o sol é rei

Meio-dia é rei croado

As quatro hora ele é morto

As seis hora é sepultado

La vai o sol se escondendo

Deixando o mundo sem luz

Só peço que não me deixe

Pelas chagas de Jesus

Domingo pela manhã, dia da Festa grande, o dia da Missa. As Caixeiras salvam o Divino cantando em frente ao altar. Continuam por boa parte da manhã e param para os preparativos para a ida à missa.

A Bandeira do Divino à frente, depois os anjos - Fé, Esperança e Caridade, o Império atrás e, fechando o cortejo, as Caixeiras. Sua passagem pelas ruas do bairro Cruzeiro do Anil chama a atenção - muita gente sai à porta para ver. As Caixeiras vão tocando e cantando, mas, ao chegar à igreja, as Caixas são deitadas e deixadas perto da porta de saída. Não é permitido tocar ou cantar no interior daquela igreja. A missa é parte integrante dos Festejos do Divino, e a Casa Fanti Ashanti a faz celebrar no domingo, dia da festa grande numa igreja no bairro vizinho, a Cohab.

É conhecido o fato de que aquele festejo do Divino é realizado num Terreiro e alguns padres em algumas paróquias os recebem com respeito, mas nem sempre com deferência. Naquela ocasião, a Santa Crôa (Corôa do Divino) colocada sobre o altar não mereceu referência do padre que celebrava a missa. E do mesmo modo, o Império do Divino, representado pelas crianças luxuosamente vestidas e sentadas no banco da frente não foi mencionado. É comum que, ao encomendar a missa, as pessoas representantes das Casas não se sintam à vontade para dizer que se trata de uma festa de Terreiro. Esse ainda é um estigma.

Terreiros antigos como a Casa de Nagô e a Casa das Minas, por exemplo, têm uma outra relação com a igreja. Sua festa tem a cerimônia de coroação do Império feita pelo padre, na igreja, ao final da missa da quinta feira da Ascensão. As Caixeiras têm repertório para a 
ocasião e ao sair, saem de costas, em clara referência aos rituais dos Terreiros. Cantando, tocando mantêm a frente do corpo voltada para o altar em respeito à divindade à sua frente. São respeitos mútuos.

Pelas ruas o cortejo volta e as Caixeiras vão tocando e cantando o Hino de Procissão, que também se estrutura por diálogo entre o tema e os comentários em versos feitos por elas. $\mathrm{Na}$ chegada, o cortejo leva a missa ao Mastro, cantando e girando ao seu redor 3 vezes no sentido anti-horário. Em seguida, param na entrada da Casa cantando pedidos de licença para entrar. Uma das Caixeiras, ou uma filha de Santo da Casa, incensa a porta e derrama água em frente à porta de entrada. Outra recebe o cortejo, respondendo ao pedido de licença feito pela Caixeira Régia que lidera o ritual.

Uma vez na Tribuna, a Caixeira Régia canta, dirigindo-se à pessoa que está como Mestre-Sala e orientando as minuciosas tarefas nesse momento. O Mestre-Sala recebe e coloca no Altar cada uma das hierofanias: os depositários do sagrado. Ajuda cada personagem do Império a se sentar em seu Trono, obedecendo à hierarquia: o par de Imperador e Imperatriz, Mordomos Régios e depois os anjos sem asas - Fé, Esperança e Caridade. Reproduzo parcialmente esse processo.

Meu senhor seu mestre-sala

Eu com vós quero falar

Receba Santa Crôa

Ponha ela no altar

Meu senhor seu mestre-sala

Peço-lhe grande favor

Faça-me a gentileza

Sente o imperador

Lá vai o pombo avoando

Lá por cima da matriz

Meu senhor seu mestre-sala

Vem sentar Imperatriz 


\begin{abstract}
Já sentou Imperatriz
Com todo seu privilégio

O senhor seu mestre sala

Sente os Mordomo Régio
\end{abstract}

Meu Divino Espirito Santo

Escute o que eu vou cantar

Se eu não fiz a seu gosto

Vós queira me perdoar

$\mathrm{Na}$ sequência, as Caixeiras dançam para o Império para em seguida arriarem suas Caixas e descansar um pouquinho. Mas logo se aproxima a hora de almoço e é preciso levar o Império para a mesa. Novamente cada uma das crianças desce de seu Trono com a ajuda do(a) Mestre-Sala e seguem em cortejo acompanhadas pelo canto das Caixeiras, em direção à mesa onde serão servidas. E aí é com Santana!

\title{
3.8 - Senhora Santana
}

O Toque Senhora Santana também se estrutura por ciclos rítmicos que se repetem construindo um tempo que se move em círculos. 


\section{Senhora Santana}
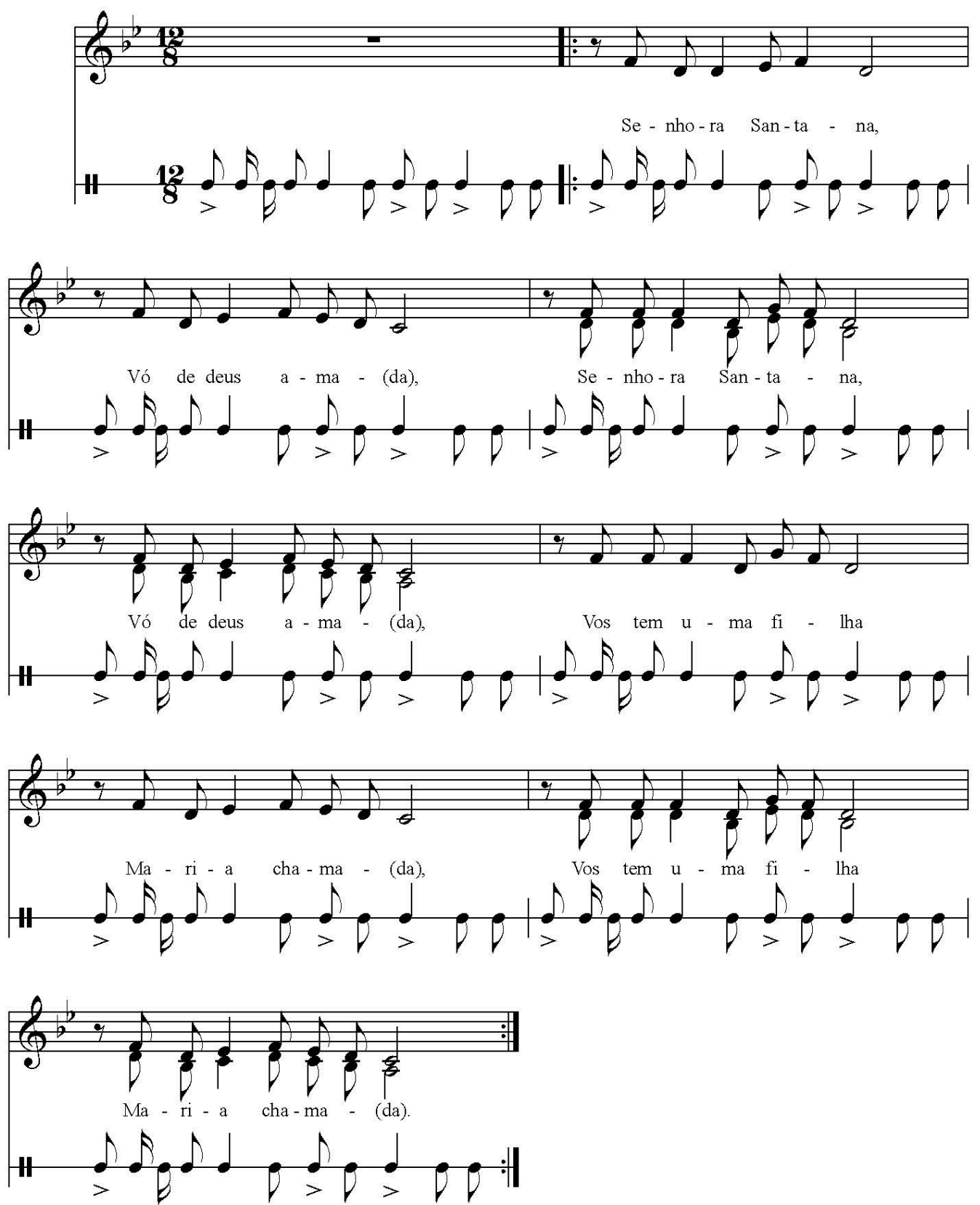

Figura 14 - Partitura de Senhora Santana

Aqui temos novamente a presença da hemíola estruturando o Toque. Figuras rítmicas múltiplas e desiguais subordinadas à ordem do pulso, constituindo um "caráter recorrente que nos parece estático, mas é bem mais extático, hipnótico, a experiência de um tempo circular, do qual é difícil sair depois que se entra porque é sem fim" (WISNICK, 1989, p.78). 
Senhora Santana

Vó de Deus amada

Vós tens uma filha

Maria chamada

Senhora Santana

Que vós tá fazendo

Peneirando trigo

Trigo está rendendo

Senhora Santana

Senhor S. Joaquim

Queira nos valer

Senhor do Bonfim

Santana teve Maria

Maria teve Jesus

O nome que lhe botaram

Manuel da Vera Cruz
Ai Manoel, Manuelzinho
Nome de nosso senhor
Se Manuel fosse padre
Seria meu confessor

Santana é a avó de Cristo, a mãe de Maria segundo a tradição cristã, e se integra ao repertório das Caixeiras. Uma ancestral, uma avó é levada para este culto festivo para o Divino, apesar do grande trabalho do cristianismo em afastar a presença das mulheres.

O Império come em pé com as Caixeiras ao redor. Elas acompanham a refeição, e seu canto descreve a mesa, elogiando-a e a quem a preparou, fazendo votos de uma boa refeição ao Império, desejando que o Divino os abençoe, reclamando se demoram muito, avisando que 
estão cansadas... O Toque para o acompanhamento das refeições do Império é o Senhora Santana. Sobre essa base rítmico-melódica cantam-se versos conhecidos e muitos improvisos:

Ó que mesa tão bonita

Nela não the falta nada

Só falta manjar do céu

E a hóstia consagrada.

Ó que mesa tão bonita

Mesa de grande valor

Esprito Santo abençoe

Quem essa mesa aprontou

Ô laranjeira da ciência

Quantas laranja botou,

Botou uma botou duas

Pra mesa do Imperador

E se as crianças estão demorando...

Imperador Imperatriz

Da glória celestial

Caixeira tá perguntando

Se acabaram de manjar

Quando terminam, é hora de voltar para a Tribuna, ou o Tribunal.

Ô Bandeireiro, Bandeireiro

Que é da bandeira real

Convidai os seus Impérios

Pra levar pro Tribunal.

Arreda povo arreda

Deixa os Impérios passar

Passa o Cetro e passa a Crôa 
Passa a Bandeira Real.

Reconduzido à Tribuna pelas Caixeiras, as crianças do Império se despem das roupas rituais e até a metade da tarde vão descansar e ou brincar. Agora as Caixeiras vão almoçar. Esses Festejos se pautam pela ideologia da igualdade e abundância e, desse modo, todos os presentes serão convidados a almoçar e participar da abundância ligada aos princípios do Divino. As Caixeiras são servidas na mesma mesa e desfrutarão do mesmo cardápio que o Império.

Quando em trabalho de campo, participei, como Caixeira, de um almoço que elas rapidamente transformaram em brincadeira. Imediatamente, mandaram chamar os parentes da Imperatriz e do Imperador e botaram versos pedindo cerveja e todas bebemos. Pequenos grupos se juntaram para, em um código construído pelo tempo de conhecimento, comentarem as situações embaraçosas, rindo muito... Uma das mais velhas botou um verso, me instigando, como novata, a respondê-lo;

Esta moça tá me olhando

Com esse olhar de raposa

Pelo jeito que me olha

Quer dizer alguma coisa

Respondi criando texto e prosódia corretos, mas sem entender como o fiz!

Esses desafios são parte do aprendizado e da construção da capacidade de improviso, cujo desenvolvimento é fundamental para ser reconhecida pela irmandade como Caixeira habilitada a pertencer àquele universo. À tarde, após o almoço e o descanso, elas voltam à Tribuna.

Quando outras Caixeiras conhecidas chegam em visita à festa, podem ser convidadas a sentar-se para tocar juntas, oferecem uma caixa e ela se integra. Acontece também de chegar alguma que o grupo não conhece e ela tem espaço para botar um verso e pedir licença para participar. Ela certamente integrará a roda, poderá botar as cantigas e Toques que traz de sua Casa e, nesse processo, trocar, ampliando repertórios. 


\title{
3.9 - Cai o Mastro!
}

No final do mesmo dia o Mastro é derrubado. Antes disso, o Império, as Caixeiras e os visitantes fazem um cortejo pelas ruas do bairro, percorrendo o caminho até o Cruzeiro em frente à Igreja de São Sebastião, não muito distante da Casa. Circulam-no por três vezes no sentido anti-horário e retornam para a cerimônia de derrubamento do Mastro. O mesmo Toque do levantamento: Nossa Senhora da Guia.

\author{
Nossa Senhora da Guia \\ Tá com a frente para o mar \\ Para ver seu bento filho \\ Quando vem de Portugal
}

Oliveira deitou rama

Oliveira deitou flor

Onde os passarinho canta

Pra alegria do Senhor
Não machuque o oliveira
Que ele tem azeite fino
Ele sempre alumeia
O sacramento divino

O Mastro é derrubado com o apoio das tesouras de vara de madeira amarradas em X. É preciso mudar o Toque, não mais o Nossa Senhora Da Guia. Agora as Caixeiras tocam o Espírito Santo Dobrado, com versos que dialogam com o momento.
Quando corta o oliveira
Como dói meu coração
Me corre água dos olhos
Me faz um poço no chão 


\begin{abstract}
Ai tesoureiro, tesoureiro
Põe a tesoura na mão

Tem cuidado tesoureiro

Não deixa cair no chão

Meu coração tava triste

Mas agora se alegrou

O Mastro do Esprito Santo

Graças a Deus se deitou...
\end{abstract}

O Mastro é deitado no chão e circundado pelo cortejo por três vezes no sentido anti-horário. Ao final, rufos das Caixas e uma sensação coletiva de degelo das tensões. Alívio! Tudo correu bem.

A Festa está terminando, chega o momento do Passamento das Posses, quando as hierofanias ligadas ao Divino são entregues para os personagens do Império do próximo ano. A Imperatriz, o Imperador e suas famílias completaram seu ciclo na festa e outros vêm chegando para serem reconhecidos, agora, nas posições que ocuparão no próximo ano.

As crianças, Imperatriz e Imperador do Império do Divino da festa passada costumam chorar, assustados diante da perda pública de sua posição. Na Tribuna, cenário da Festa no interior da Casa, diante de todos, Corre Beirada, carregado por Pai Euclides, canta dirigindo-se às Mordomas e à Imperatriz no processo de Passamento das Posses. A cada verso cantado, as hierofanias, os depositários do sagrado e símbolos do poder conferido por seus cargos, são retirados das personagens com a ajuda do(a) Mestre-Sala. O mesmo processo acontece, em seguida, com o Imperador.

Os mesmos objetos retirados dos ocupantes dos cargos são colocados naqueles que irão ocupar o mesmo cargo, no ano seguinte. Mordoma e Mordomo Mór receberão os símbolos dos atuais Mordomos Régios, que por sua vez receberão as posses do par de Imperador e Imperatriz, que saem da Festa depois de ter passado por todos esses cargos durante três anos. É comum que essas crianças ou pré-adolescentes, idade em que geralmente participam da festa, chorem nesse momento. As cantigas nos informam esse processo. 


\section{Passamento das Posses:}

Minha nobre Imperatriz

Um recado eu vim lhe dar

Me entregue esta cadeira

Para outra se assentar

Minha nobre Imperatriz

Tão bonita a sua sorte

Quero que você me entregue

A coroa e seu capote

Minha nobre Mordoma Régia

Com você quero falar

Me entregue sua grinalda

Para outra eu lhe entregar

Ah minha Mordoma Mór

Com você quero falar

Me arreceba esta grinalda

Divino mandou eu lhe dar

Receba Mordoma Régia

Com prazer no coração

A coroa e seu capote

Pra governar no salão

Vivas! Rufos das caixas e palmas!

Minha nobre Imperatriz

Tão bonita sua sorte

Vou pedir pra Deus Divino 
Que lhe dê uma boa sorte

Minha nobre Imperatriz

Que foi da festa passada

Nunca perdeu o direito

De servir à majestade

Minha nobre imperatriz

É uma pessoa tão boa

Quero que você me entregue

Divina Santa Coroa

Receba Mordoma Régia

Na palma das suas mãos

Como se recebe a hóstia

Na mesa da comunhão

Minha nobre Imperatriz

Minha flor de jardineira

É chegada a sua hora

Se despeça de suas Caixeiras

Sobre palácio de reis

na igreja da matriz

Estas hora a majestade

É a nova Imperatriz

Caixeiras de Espírito Santo

Eu quero the agradecer

Deus lhe dê felicidade

Conforme seu merecer 
Kabeca, a Mãe Pequena e Caixeira Régia da Casa, continua o processo. Dirige-se aos Mordomos e ao Imperador, despindo-os amorosamente dos símbolos de realeza que reafirmaram a sua posição no centro da Festa.

O meu nobre Imperador

Dê-me licença riá

Dê-me licença que eu entre

No seu rico Tribunal

Lá vai o pombo avoando

Com todo seu privilégio

Espirito Santo me mandou

Que eu fale com Mordomo Régio

Meu Divino Espirito santo

Vem descendo lá do céu

Santa Crôa me mandou

Que eu lhe peça o seu chapéu

Lá vai o pombo avoando

Por cima da gameleira

Meu nobre Mordomo Régio

Levante da sua cadeira

Bom Jesus de Nazaré

É o pai da majestade

Espírito Santo me mandou

Que eu receba sua espada

O meu nobre Mordomo Mor

Eu com vós quero falar

Arreceba estes apetrechos 
Pro vosso ano governar

Lá vem vindo de Lisboa

O Espírito Santo certo

O meu nobre Imperador

Me entregue o vosso cetro

Meu Divino Espírito Santo

Divino Santo riá

Me entregue vossa coroa

Para a outro eu entregar

O meu nobre Imperador

Olhos de estrela do norte

Santa Crôa lhe mandou

Me entregar vosso capote

O meu nobre Imperador

Lhe fiquei muito obrigada

Já me entregou o seu capote

Me entregue vossa espada

O meu nobre Mordomo-Régio

Receba de coração

Aceite esta divina coroa

De todo seu coração

O meu nobre Mordomo Régio

Grande foi a sua sorte

Espírito Santo lhe mandou

Que receba este capote 
Divina Santa Coroa

É uma hóstia consagrada

O meu nobre Mordomo Régio

Aceite o cetro e essa espada

Ô meu nobre Imperador

Olhos de estrela do norte

Vou pedir a Espírito Santo

Que lhe dê uma boa sorte

Deus lhe pague, Deus lhe ajude

Deus lhe dê muito que dá

Deus lhe dê muito dinheiro

Que você não saiba contar

Lá vai o pombo avoando

Por cima da gameleira

O meu nobre Imperador

Se despeça das Caixeiras

Meu Divino Espírito Santo

Eu com vós quero falar

Se não saiu a seu gosto

Vós queira me perdoar

O senhor dono da festa

Esta vai a seu louvor

Não há ouro e não há prata

Que mereça seu valor

Corre Beirada, carregado por Pai Euclides, canta para as Caixeiras: 
Caixeira de Espírito Santo

Lhe fico muito obrigado

Se vós precisar de mim

Estarei sempre ao seu lado

Minha linda Santa Crôa

Vais pra seu estado real

Nós fizemo obrigação

Das côrtes Imperial

Caixeira de Espírito Santo

Já cheguei até aqui

Falam o que quiser falar

Na hora de despedir

\subsection{0 - Fechamento da Tribuna, final do festejo}

Nesse momento, por sua importância e sacralidade, não cabem erros. Todo o processo descrito na Abertura da Tribuna descreve agora o Fechamento desse espaço-tempo. $\mathrm{O}$ repertório pode variar entre os Festejos, ainda que o Bendito de Hortelã esteja integrado aos festejos em Terreiros como a Casa Fanti Ashanti. As Caixeiras tocam e cantam com muito mais atenção que o habitual. Erros seriam evidentes, dada a relação entre o canto e o toque das Caixas que se alternam nesse momento, criando uma ambiência carregada de gravidade majestática. As Caixas silenciam para ouvir o canto que, por sua vez, silencia ao toque das Caixas. Não cabem imprecisões. 


\subsection{1 - Despedida das Caixeiras}

O Toque Arreia caixa no chão é especifico para esse momento. O grupo canta em pé e quando todas botaram seu verso de despedida, arreiam, colocam as caixas no chão. Essas serão guardadas e voltarão a ser usadas no ano seguinte.

As Caixeiras se despedem, manifestando pesar pelo término do Festejo, pois terão que se afastar das companheiras. Em seu discurso em versos, colocam-se sempre à disposição de servir e cultuar o Divino, reafirmando a sua devoção e pedindo graças, proteção e saúde para si mesmas e suas famílias.

Refrão: Arreia Caixeira arreia, arreia caixa no chão

Arreia Caixeira arreia, arreia caixa no chão

Eu vou dar a despedida

As costas já vou virando

Eu não sei quem fica atrás

Meus olhos já vão chorando

Eu vou dar a despedida

Como ave de arribar

Espero Espírito Santo

Para o ano eu voltar

Eu vou dar a despedida

Como a ave que avoa

Me despeço dos Império

E também da Santa Crôa

Meu Divino Espírito Santo

Tanto que lhe quero bem

Vós me dê sua saúde 
Sou sua devota também.

\subsection{2 - O Carimbó de Caixeiras!}

O final do Festejo costuma ser marcado pela brincadeira denominada Carimbó de Caixeiras, Carimbó das Velhas, Bambaê de Caixas, Farra de Caixas. Incluído no roteiro ritual, esse momento pode se associar ao Serramento do Mastro no Lava Pratos da festa, quando as Caixeiras brincam depois de muitos dias de dedicação ao Festejo.

Os caboclos e encantados que frequentam a Casa se integram a esse momento, cantando, dançando e improvisando versos no diálogo com os participantes da festa. Os poemas fazem a crônica social, dialogando com os cotidianos, novidades, brincadeiras de duplo sentido, e são frequentes os desafios e improvisos. A música nesse momento é o repertório de versos e brincadeiras desses caboclos, em particular Antônio Luís Corre Beirada, carregado por Pai Euclides, mas também muitos outros que chegam para brincar.

O Festejo na Casa só termina após os quatro dias de Toque de Tambor de Mina e três dias de Toque do Candomblé, as duas estruturas religiosas existentes e praticadas na Casa Fanti Ashanti.

A música tocada nesse momento se apoia em uma célula rítmica, presente em grande parte da música popular brasileira e identificada por Kazadi Wa Mukuna, como de matriz centro-africana, banta, inclui a síncope . (MUKUNA, 2006).

O Carimbó designa a festa e o Toque desse momento. É a base rítmica para a brincadeira das Caixeiras que pode ser encontrada em diálogo com diversas formações instrumentais e estruturas de perguntas e respostas. Canto e palmas, canto e uma garrafa, tocada com uma baqueta, que com seu som agudo é responsável pela manutenção constante do cerne estrutural da música: o seu padrão rítmico. Mas pode haver, também, caixas tocadas por homens ou mulheres que participam da festa ou pelas próprias Caixeiras.

Ô dona da casa,

Eu tô na fuzarca

Se não tiver copo

Me dê que eu bebo é na garrafa (Cantiga do Carimbó na Casa das Minas) 


\section{AQUILO É DAQUELAS PRETADAS VELHAS, ANTIGAS, ESCRAVAS! AS CONSIDERAÇÕES FINAIS}

Esta pesquisa objetivou conhecer a música das Caixeiras do Divino em suas formas contemporâneas, compreendidas como uma construção musical desenvolvida em zonas de contato entre populações e culturas construídas nesse processo. Esta realidade aporta informações sobre a nossa formação intercultural, multiétnica, transnacional presentes aqui.

As reflexões sobre diáspora e seus conceitos, presentes em todo o trabalho, e em particular no Capitulo 2, apoiaram a compreensão do olhar para a realidade construída em processos de livre apropriação e recombinação de elementos musicais. A pluralidade de sons articulados em rítmicas complexas evidencia estruturas musicais como produto de uma cultura de miscigenações.

No capítulo 3, esta compreensão orientou a pesquisa com o apoio de análises estruturais, dessa sonoridade produzida por estruturas com características que remontam, pelos menos, ao período medieval: o canto monódico uníssono e organização rítmica ternária. Estas estruturas se articulam com a presença de circularidade temporal e associam-se a gestos, palavras, epistemes e espiritualidades de matriz africana. Uma construção que reúne Caixeiras e participantes dos festejos em uma experiência corporal do sagrado, vivenciada coletivamente.

Sua música tem uma formação instrumental que se orienta pelo canto e a percussão de Caixas, e não pude identificar polirritmias, o uníssono é a norma. Cantam em grupos, tocando tambores graves; uma referência aos tambores-mãe em culturas de Áfricas e a outros grupos que também reúnem mulheres em formação semelhante. Alguns exemplos são: as Adufeiras em Portugal, com seus pandeiros quadrados bi-membranofones, os Adufes (do árabe adüf), na Região da Beira Baixa. As Pandereteras com Panderetas, na Galícia, e também as Copleras, no norte argentino, com suas Cajas. Alguns exemplos de um universo a ser visibilizado.

Os dados históricos e de organização política do espaço no estado do Maranhão, presentes neste estudo, ofereceram um panorama da dificuldade dos trajetos (por mar até o Maranhão, e por terra, entre o Estado do Grão Pará e Maranhão e o Estado do Brasil), aliados a dados de movimento e origem das populações que para ali foram levadas. Essas informações apoiam a visibilização de uma zona de contato formada por povos africanos, europeus, açorianos e indígenas, e que se comunicava mais facilmente com a Europa. Esse 
fato manteve por muito tempo um certo grau de isolamento interno daquela região em relação a outras regiões do Brasil.

Com o apoio de mapas de divisão política das microrregiões do estado do Maranhão, no Capítulo 2, pude observar que a maior frequência de festejos do Divino está nas regiões que circundam o porto de chegada à Ilha de S. Luís e no caminho dos grandes rios que adentram o território. A existência, nessas regiões, de festejos que compartilham uma estrutura rítmica, performática e de significados, aponta para a difusão de uma estrutura musical a partir do mar e grandes rios.

As Caixeiras do Divino na Baixada Maranhense possuem uma forma de cantar que se assemelha ao canto dos boieiros, os brincantes de Bumba Meu Boi, uma tradição de grande popularidade na região.

Pude observar que o Divino é também cultuado como consolador em rituais relacionados à morte que compartilham estruturas musicais com as Caixeiras. Estes, podem ser encontrados com maior frequência nas proximidades da divisa com o Piauí. Envolvem cantorias em visitas de cova, acompanhamento de enterros, pagamento de promessas, e são conduzidos pelos Foliões da Divindade cantando e tocando em duplas. Estes ritos possuem também grande diversidade do ponto de vista musical, incluindo diferentes formações instrumentais.

Estas realidades ressaltam a continuidade da diáspora, das construções de zonas de contato, nas quais essas estruturas musicais performáticas e simbólicas de devoção ao Divino são incorporadas, reinventadas e ressignificadas no diálogo com outras cosmogonias ali existentes. Esse fato aponta futuras pesquisas para identificação destas construções, compreensão e mapeamento da diversidade de formas e significados atribuídos aos cultos festivos para o Divino.

Falando em significados atribuídos, repito aqui um trecho da fala de D. Margarida Maria de Araújo, antiga Caixeira Mór em Alcântara, que foi apresentada neste trabalho à pagina 59 .

Repara que quando a gente canta Alvorada dentro daquele salão, aquilo faz um silêncio! Aquilo é daquelas pretadas velhas, antigas, escravas! Isso é do tempo da escravatura! E nesse tempo, era elas era quem mandava nessa festa. Era elas e os home! Aqueles preto escravo, tudo era quem sabia tocar, era quem tirava esses cântico, esses toque, eles era quem fazia... 
O significado que ela atribui àquele Toque o distingue dos demais integrando-o ao patrimônio de sua comunidade ampliada, incorporando assim uma herança africana, escrava. Ao definir este espaço simbólico, ela constrói uma narrativa que coloca a música com a qual as Caixeiras conduzem os cultos festivos para o Divino, no centro daquele coletivo.

D. Margarida viveu e participou ativamente da luta pela terra durante a maior parte de sua vida na Vila do Cajueiro, onde viveu, no município de Alcântara, como liderança da luta pela permanência no território que construiu seu modo de viver por gerações inteiras. ${ }^{27}$

Michael de Certeau contribui para a compreensão do pensamento de D. Margarida.

É possível ver no indício de uma religiosidade em expansão, o refluxo de uma cultura popular em direção à única linguagem que ainda lhe permite exprimir-se diante do triunfo da razão que desejaria negá-la. A linguagem da religião poderia, nesse caso, ser o ultimo recurso de uma cultura que não pode mais se manifestar e que deve se calar ou se disfarçar para que se faça ouvir uma ordem cultural diferente. (CERTEAU, JULIA e REVEL Apud ANTONACCI 2013, p. 69)

D. Margarida prossegue dizendo: "Por uma dessa é que hoje em S. Luís não tem um Toque igual o nosso e nem o nosso é igual ao deles!"

A análise e audição do Toque Alvorada, ao qual D. Margarida se refere, não oferece distinções significativas do ponto de vista das estruturas musicais ou performáticas. Para compartilhar essa compreensão anexo, a seguir, partituras da cantiga e Toque Alvorada na Casa Fanti Ashanti e da Alvorada que encerra o Levantamento do Mastro em Alcântara, o mesmo toque ao qual ela se referiu quando disse: "Repara que quando a gente canta Alvorada dentro daquele salão, aquilo faz um silêncio!”

A compreensão da profundidade de sua afirmação, requer a visibilização de questões históricas, políticas, epistemes e formas de ser, viver e memorizar de comunidades que hoje denominamos tradicionais. Estas sempre viveram e vivem cosmogonias que integram dimensões espirituais e materiais.

\footnotetext{
${ }^{27}$ Cajueiro foi uma das dezenas de comunidades retiradas da terra que ocupavam há mais de duas centenas de anos, em um processo de desapropriação para construção da Base de Alcântara. Um processo extenso e conflituoso, no qual a sua população foi "realocada" na Agrovila do Cajueiro. Ficaram distante do mar e dos recursos que a população sabia usar para garantir seu sustento que se estruturava em redes de trocas, mutualidades, uso comum de terras em uma grande densidade de realidades. Esta é uma comunidade reconhecida como Quilombo. Para compreensão da realidade dos quilombos no Maranhão, sugiro as reflexões de Maristela de Paula Andrade: Quilombolas - etnicidades emergentes. Subsídios para uma discussão. In Ciências Humanas em Revista. S. Luís, V.04, N1. Junho 2006, dentre outros textos.
} 


\section{REFERÊNCIAS}

AGAWU, Kofi. Analyzing Music under the New Musicological Regime. In: The Journal of Musicology, Vol. 15, No. 3 (Summer, 1997), pp. 297-307 Published by: University of California Press Stable URL: http://www.jstor.org/stable/763911. Accessed: 26/03/2013 $12: 38$

ANDERSON, Benedict, 1991 (1983), Imagined Communities. Reflections on the Origin and Spread of Nationalism, New York, Verso.

ANDRADE, Andreza de Oliveira. Gênero e História das Mulheres: Diálogos conceituais. Biblioteca da Universidade Livre Feminista. http://www.bibliotecafeminista.org.br/index.php?option=com_remository\&Itemid $=53 \&$ func $=$ fileinfo\&id $=52$

ANDRADE, Maristela de Paula: Quilombolas - etnicidades emergentes. Subsídios para uma discussão. In: Ciências Humanas em Revista. S. Luís, V.04, N1. Junho 2006.

ANTONNACCI, M. Antonieta. No corpo a corpo, letra, voz, imagens em culturas africanas e afro-brasileiras. VII Congresso Luso-brasileiro de ciências sociais. Coimbra 2004 . Memórias Ancoradas em Corpos Negros, São Paulo, EDUC, 2013.

ARAÚJO, Maria Marta Lobo de. A ajuda aos pobres na Confraria de Nossa Senhora da Guia e do Espirito Santo de Ponte de Lima. Sec. XVII a XIX. Edição da Câmara Municipal de Braga. Separata do Vol. I da Revista Cultural BRACARA AUGUSTA Braga- 2001/02

As traves mestras da Confraria do Santíssimo Sacramento da igreja da Misericórdia de Vila Viçosa: o compromisso de 1612. Porto: Sociedade Portuguesa de Antropologia e Etnologia, 2001. p. 137-150. Sep. dos “Trabalhos de Antropologia e Etnologia”, vol. 41, n. 34 (2001).

AVICK, Philip J, A dinâmica das relações de Gênero e Parentesco num contexto comercial: Um Balanço comparativo da Produção Histórica sobre a Região da Guiné-Bissau séculos XVII e XIX. In Afro-Ásia, 27 (2002), 79-120.

AZEVEDO, Rui Pinto de - O Compromisso da Confraria do Espírito Santo de Benavente. $\begin{array}{llllllll}\text { Lusitania } & \text { Sacra. } & \text { Lisboa. } & \text { ISSN } & \text { 0076-1508. } & 6 & (1962-1963) & 7-23\end{array}$ 
http://repositorio.ucp.pt/bitstream/10400.14/5053/1/LS_S1_06_RuiPAzevedo.pdf acesso $10 / 09 / 2014$.

BARBOSA, Marise Glória. Umas Mulheres que dão no Couro: As Caixeiras do Divino no Maranhão. Dissertação Mestrado em Historia - PUC São Paulo-SP 2002.

. No Bater da Minha Caixa Estou Convidando as Foliôa Iphan - MA 2009

BARTOlOMEU DE ARAÚJO, Ana Cristina Cardoso dos Santos - A Morte em Lisboa: Atitudes e representações 1700-1830. Coimbra, ed. aut., 1995.

BRÁGIO, Antonio; As Confrarias Medievais do Espírito Santo, Paradigmas das Misericórdias. Lisboa Academia Portuguesa de História. (Separata de Presença de Portugal no Mundo), s/d.

CAMPOS Marize Helena de, As Donas do Poder: economia e vida material de mulheres no Maranhão colonial (1755-1822) Fapema 2015.

CARNEIRO, Sueli. A mulher negra. Cadernos Geledés. Instituto da Mulher Negra. 1993. S. Paulo.

$$
\text { Enegrecer } \quad \text { o } \quad \text { Feminismo }
$$

http://www.bibliotecafeminista.org.br/index.php?option=com_remository\&Itemid $=56 \&$ func $=$ fileinfo\&id $=208$

CASTRO MONTEIRO, Ricardo Nogueira de. A métrica como ferramenta para a analise da canção: Feitio de Oração, de Francisco Alves a Bete Carvalho. Revista ANPOLL n. 6/7 pp. $175-254$ Jan/Dez 1999

https://www.anpoll.org.br/revista/index.php/revista/article/viewFile/343/352 - visualizada em 09 de junho 2014.

CERTEAU, Michael de. A Invenção do Cotidiano. São Paulo, Editora Vozes 1994.

COHEN, Judith R. CanoSoe joglaresa: Women and music in Medieval Spain's: Three Cultures. In Medieval Woman's Song Cross Cultural Aproaches. University of Pennsilvania Press 1997.

COOK, Nicholas. Agora somos todos (etno)musicólogos. Ictus 07 - Pg 07-32. Trad. de Pablo Sotuyo Blanco. s/d. 
CORRÊA, Antenor Ferreira - Os Sentidos da Análise Musical in; Revista Opus 12 - (33-53). 2006

COSTA EDUARDO, Otávio. O Tocador de Atabaques nas Casas de Culto Afro Maranhenses. Memoires de l'institut Français d'Afrique Noire n. 27 - Les Afro-americain . IFAN Dakar 1952.

COUTO, Mia: Um rio chamado tempo, uma casa chamada terra. Companhia das Letras, São Paulo, 2003.

DRINKER, Sophie Music and Woman: The history of woman in their relation with music. New York, Coward McCann, 1943.

ESPIRITO SANTO, Moisés. Origens orientais da religião popular portuguesa. Lisboa, 1988. Ed. Assírio \& Alvim.

FERREIRA, Euclides Meneses. Casa Fanti - Ashanti e seu Alaxé. Ed. Alcântara, São Luís, 1987

FERRETTI, Sergio F. Repensando o sincretismo - EDUSP. São Paulo, 1995.

FREITAS, Paulo Sergio Ribeiro de. Da_musica_como_criatura_viva_repercussoes_do_organicismo_na_teoria_contemporanea. In http://www.academia.edu/2348999/.

GILROY, Paul. Modernidade e Dupla Consciência. Universidade Cândido Mendes, Trad. Cid Knipel Moreira SP. Ed. 34. Rio de Janeiro. Instituto de Estudos Afro-Asiáticos, 2001

GIMBUTAS, Marija. The Language of the goddess. Harper San Francisco, 1989.

GONZALEZ, Juan Pablo Musicología popular en América Latina: síntesis de sus logros, problemas y desafíos. Revista Musical Chilena v.55 n.195 Santiago enero, 2001

GOUVEIA, Claudia. Personalidades de um rito festivo. Boletim on line no Site da Comissão Maranhense de Folclore, Agosto de 2000.

GROUT, Donald j. et PALISCA, Claude V. Historia da Música Ocidental;. Gradiva Publicações Ltda. Lisboa, 1994. 
HALL, Stuart, Da Diáspora. Identidades e Mediações Culturais. Org. Liv Solvik; Trad. Adelaine La Guardia Resende... (et All) Belo Horizonte; Editora UFMG, 2003.

HAMPATÉ BÁ, Amadou. A Tradição Viva. História geral da África, I: Metodologia e préhistória da África / editado por Joseph Ki-Zerbo. - 2.ed. rev. - Brasília : UNESCO, 2010. 992 p.

IKEDA, Alberto, DIAS, Paulo e CARVALHO, Sergio. Cachuera! de Música - Ritmo e percussão.

Disponível

em

http://www.cachuera.org.br/cachuerav02/index.php?option=com_content\&view=article\&id=1 42: cachuera-de-musica-ritmo\&catid $=91$ : cachuerademusica\&Itemid $=115$

KERMAN, Joseph. How We Got into Analysis, and How to Get out. In Critical Inquiry, Vol. 7, No. 2 (Winter, 1980), pp. 311-331 Published by: The University of Chicago Press Article. Stable URL: http://www.jstor.org/stable/1343130

LEAL, João, "Festas do divino em São Luís: um retrato de grupo", Boletim da Comissão Maranhense de Folclore, 53, 2012. pp3-7, ISSN 1516-1781

. 2009a, "Rituais em Trânsito: Festas do Espírito Santo, Transnacionalidade, Etnicidade", Jorge Crespo. Estudos em Homenagem, Lisboa, Sem Luz, 57- 80.

2009b, "Travelling Rituals. Azorean Holy Ghost Festivals in Southeastern New England", Holton, K. \& A. Klimt (eds.), Community, Culture and the Makings of Identity. Portuguese-Americans Along the Eastern Seaboard, Dartmouth MA, Center for Portuguese Studies and Culture - University of Massachusetts (Dartmouth), 127-144.

LIMA, Carlos de. Festa do Divino Espirito Santo em Alcântara -Maranhão. São Luís 1972 Edição Particular - Segunda edição em 1988, Fundação Pró-Memória - Brasília.

MACEDO, José Rivair. Org. http://www.academia.edu/975682/A_Idade_Media_Portuguesa_e_o_Brasil_reminiscencias_tr ansformacoes_ressignificacoes. Porto Alegre, Vidráguas, 2011. Acessado em 10/09/2014

McCLARY, Susan. Conventional Wisdom: The Content of Musical Form. University of California Press. London, 2000.

Of patriarchs and matriarchs, too. The Musical Times, Vol. 135, No. 1816, 150th Anniversary Issue (Jun., 1994), pp. 364- 369. 
MELLO, Maria Ignez Cruz. Relações de gênero e musicologia: reflexões para uma análise do contexto brasileiro. In Revista eletrônica de musicologia. Volume XI - Setembro 2007.

MIGNOLO, Walter. Desobediência Epistémica. Retórica de la modernidade, logica de la colonialidad y gramática de la descolonialidad. Ed. Buenos Aires. Ediciones Del Signo, 2010.

MINTZ, Sidney; PRICE, Richard. O nascimento da cultura Afro-Americana. Uma perspectiva antropológica. Traduzido por Vera Ribeiro. Rio de Janeiro: Pallas - Universidade Cândido Mendes, 2003.

MOLINO, Jean. Analyser. In L'Analyse musicale. N.16, 01/06/1989, PP. 11-13 - juin 1989. Tradução de Adriano Gado.

MONTES, Maria Lúcia. As Caixeiras do Divino: tradição e inovação na metrópole. Este texto está como encarte do CD O Divino Som - Caixeiras da Família Menezes, vol. 2 Associação Cultural Cachuera! - $\quad$ www.cachuera.org.br Disponível em http://www.cachuera.org.br/cachuerav02/images/stories/arquivos_pdf/texto_mlm.pdf. Acessado em 08/09/2014.

MONTES, Maria Lúcia. Cosmologia e Altares. In Arte e Religiosidade no Brasil - Heranças Africanas - Texto do catálogo da exposição Projeto Pinacoteca no Parque. Segundo Encontro Nacional da Cultura. São Paulo 8/11-7/12, 1997.

MOORE, Robin: The Commercial Rumba: Afrocuban Arts as International Popular Culture. Latin American Music Review / Revista de Música Latinoamericana, Vol. 16, No. 2 (Autumn - Winter, 1995), pp. 165-198 University of Texas Press. http://www.jstor.org/stable/780372 Baixado em 11/11/2014

. Reflexões sobre o caribe hispânico. Projeto História, São Paulo, n. 44, pp. 305-319, jun. 2012

MORAIS DA SILVA, Rosângela Divina Santos. Teatro Português Medieval - Cenário Histórico. Revista Philologus, Ano 16, № 46. Rio de Janeiro: CiFEFiL, jan./abr.2010

MUKUNA, Kazadi Wa. Contribuição Bantu na Música Popular Brasileira: Perspectivas Etnomusicológicas. Terceira Margem. São Paulo, 2006.

NETTL, Bruno. The Study of ethnomusicology. Thirthy-one issues and concepts. $2^{\text {nd }}$ ed. Chicago. University of Illinois Press, 2005 
OLIVEIRA, Luciana de Fátima. Estado do Maranhão e Grão-Pará: Primeiros Anos de Ocupação, Expansão e Consolidação do Território. Anais do XXVI Simpósio Nacional de História - ANPUH • São Paulo, julho 2011

OLIVEIRA PINTO, Tiago. Som e Música: questões de uma antropologia sonora. in Revista de Antropologia, São Paulo, Usp, 2001, V. 44 no 1, p 222.

PANTOJA, Selma (org.) Matronas e Mandonas: Parentesco e poder feminino nos rios de Guiné (Sec. XVIII) 2001, Brasília Marco Zero.

PERRY, Mary Elizabeth, Gender and Discorder in Early Modern Seville, Princeton Univ. Press, 1990).

PORTELLI, Alessandro. Tentando aprender um pouquinho. Algumas reflexões sobre a ética e história oral. Projeto História 15, Educ. 1997, p 26.

PRAXEDES, Vanda Lucia. De submissas a donas e mandonas: histórias e trajetórias de mulheres viúvas nas duas margens do Atlântico (1750-1880),

RAMOS, Pilar. Feminismo y música: Introducción crítica. Revista Musical Chilena, Año LXIV, Enero-Junio, 2010, N²13, pp. 7-25 7

REDMOND, Layne. When the drummers were women, New York. Three Rivers Press, 1997. RIBEIRO, Hugo Leonardo. A Análise Musical: por quê, para quem e como? XVI Congresso da Associação Nacional de Pesquisa e Pós-graduação em Música (ANPPOM) Brasília - 2006

SEEGER, Anthony. Etnografia da Música. Tradução: Giovanni Cirino, revisão técnica: André-Kees de Moraes Schouten e José Glebson Vieira. Cadernos de Campo. S. Paulo n. 17. pp 1-348, 2008.

SHEPHERD, John. Music and Cultural categories. In: The cultural study of music: a critical introduction. CLAYTON, Martin; HERBERT, Trevor; MIDDLETON, Richard (Ed). Nova Iorque e Londres: Routledge, 2003.

SIMÕES, Manuel Breda. Roteiro lexical do culto e festas do Espírito Santo nos Açores. Lisboa, Instituto de Cultura e Língua Portuguesa, 1987. 
SOUSA FILHO, Benedito. PAULA ANDRADE, Maristela de. Patrimônio Imaterial de Quilombolas. Limites da Metodologia de Inventário de Referências Culturais. Horizontes Antropológicos. Porto Alegre, ano 18, n. 38, p. 75-99, jul./dez. 2012

SOUSA. Poliana Macedo de. Festas do Espírito Santo em Portugal e Além Mar. Revista Mosaico, v. 6, n. 1, p. 107-119, jan.jul. 2013. Disponível em http://seer.ucg.br/index.php/mosaico/article/viewFile/2751/1676. Acessado em 11/09/2014

TORRES, Claudio. O extremo ocidente ibérico, in, Terras da Moura Encantada: Arte Islâmica em Portugal, Porto 1999.

VANSINA, Jean. A tradição oral e sua metodologia. In: Metodologia e História da África. 2 vol. Historia Geral da África. Unesco, 1980.

VIDEIRA, Mário - Crítica Musical em E.T.A. Hoffman. In Arte filosofia, Ouro Preto N. 8. Pg. 91-105. Abril 2010.

WERNECK, J.. . Nossos passos vêm de longe! Movimentos de mulheres negras e estratégias políticas contra o sexismo e o racismo. Revista da ABPN, América do Norte, 1, mar. 2010. Disponível em: HTTP://WWW.ABPN.ORG.BR/REVISTA/INDEX.PHP/EDICOES/ARTICLE/VIEW/20/10. Acesso em: 08 Jul. 2014.

ZUMTHOR, Paul. Introdução à poesia oral. São Paulo, Hucitec, 1997 Performance, Recepção e Leitura. Trad. Jeruza Pires Ferreira e Suely Fenerich. São Paulo Cosaq Naif, 2000.

\section{ENTREVISTAS}

CAMPOS, Marize Helena

de http://www.fapema.br/site2012/index.php?option=com_content\&view=article\&id=2736:pesq uisa-poe-em-cheque-estereotipos-das-mulheres-no-maranhao-colonial-\&catid=101:noticiasdestaque $\&$ Itemid $=117$

GIMBUTAS, Marija. The World of the Goddess. https://www.youtube.com/watch?v=yU1bEmq pf0 
VIGARELLO, Georges, em entrevista a Denise SANT'ANNA. O corpo inscrito na História. Projeto História 21. São Paulo, Educ - Fapesp 2000. Pp 229-230.

\section{DOCUMENTÁRIO}

Umas Mulheres que Dão no Couro: As Caixeiras do Divino no Maranhão. 100min. Direção e Roteiro - Marise Gloria Barbosa 


\title{
ANEXOS
}

\section{ANEXO 1 - Lista de arquivos no CD}

\author{
Alvorada - Alcântara \\ Alvorada - Casa Fanti Ashanti \\ Alvorada - Casa das Minas \\ Alvoradinha \\ Nossa Senhora da Guia \\ Senhora Santana \\ Espírito Santo Dobrado \\ Carimbó de Caixeiras - Casa das Minas \\ Carimbó de Caixeiras - Casa de Nagô
}

Vim da Mina - CD: Tambor de Mina na Virada pra Mata 
ANEXO 2: Alvorada na Casa Fanti Ashanti

Alvorada
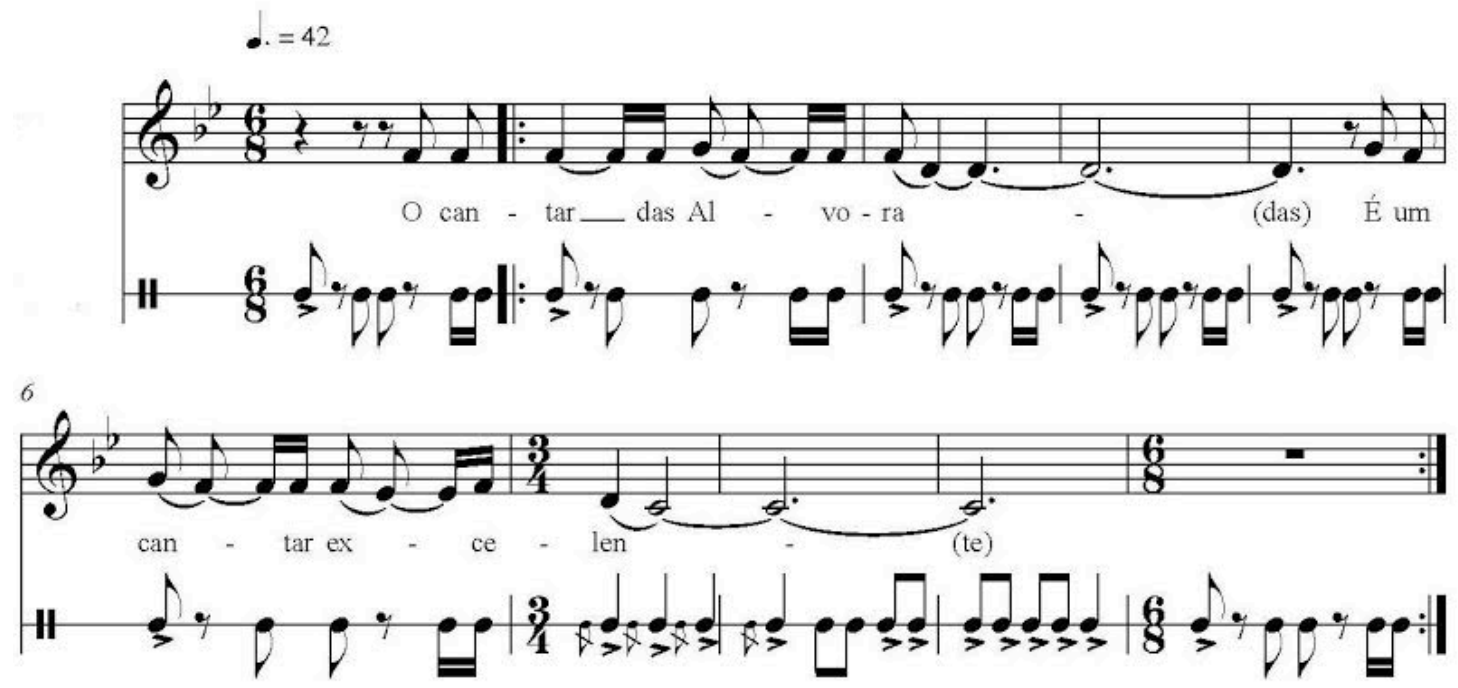


\section{ANEXO 3: Alvorada em Alcântara}

Alvorada que encerra o levantamento do Mastro

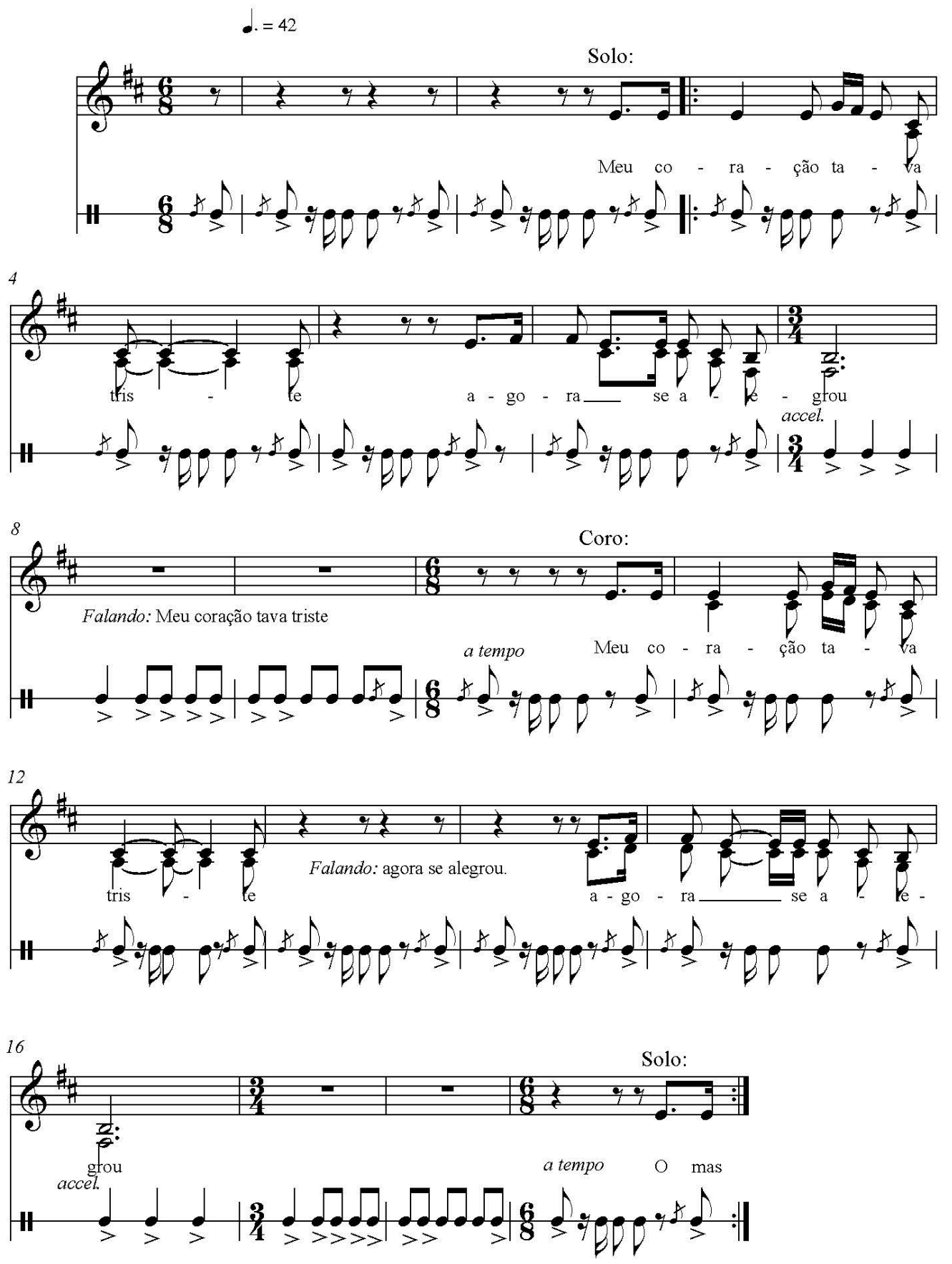

